\title{
DIOSES Y CABALLOS EN LA IBERIA PRERROMANA
}

\author{
M. P. GARCÍA-GELABERT PÉREZ \\ Universidad de Valencia \\ J. M. BLÁZQUEZ MARTÍNEZ \\ Real Academia de la Historia
}

\begin{abstract}
Vuelo, cuando me subo en horcajadas a él soy un halcón. El trota por el aire, la tierra canta cuando él la toca; el cuerno más basto de su casco es más musical que la flauta de Hermes.
\end{abstract}

Enrique V. W. Shakespeare.

\begin{abstract}
Resumen. Se aborda el tema del caballo en época prerromana desde la perspectiva de la religión. El estudio es fruto de la labor conjunta de los dos firmantes, no obstante el bloque relativo a los caballos en conexión con la vida terrenal y ésta a su vez enlazada con el ambiente de los dioses es obra de M.P.García-Gelabert; y el que trata los aspectos del caballo vinculado con la heroización y con la vida de ultratumba ha sido redactado por J.M. Blázquez.

Palabras clave: Caballo, equites, Hispania prerromana, religión de Iberia, Diosa Madre, santuarios, exvotos, heroización ecuestre, necrópolis, estelas, iberos, celtas.
\end{abstract}

\begin{abstract}
In this paper we study the horse in the Pre-Roman period from the religious point of view. The two authors have worked together in this study, but each part of the work belongs to one of them. M. P. García-Gelabert's work covers the horses in relation to earthly life and the gods, while J. M. Blázquez covers their links to heroicization and the dead.

Key words: Horse, equites, Hispania pre-roman, religion of Iberian, Goddess Mother, sanctuaries, votive offerings, heroship equestrian, necropolis, stelas, iberos, celtas.
\end{abstract}

\section{INTRODUCCIÓN}

La historia del caballo hispano en tiempos prerromanos e incluso su fama en Roma a raíz de haber conquistado la Metrópoli Iberia, ha sido objeto de expertos trabajos en los últimos tiempos. A la vista de tan ingente documentación comprensiblemente no abordamos el tema en cuanto a lo tratado por nuestros colegas. Así pues, a continuación de unas notas generales, nos limitamos a escribir acerca del caballo y su entorno ligándolo con las creencias, es decir a cómo los nativos apoyaban a sus caballerías y a la fecundidad de las mismas orando y ofreciendo sacrificios a los dioses del panteón propio y pactando con ellos, a veces en santuarios que son exclusivamente cobijo de una imagen en la que una deidad afín con los nobles brutos se manifestaba, en otros casos los santuarios a los que se dirigen los creyentes tienen un espectro más amplio de protección. Nos proponemos inferirlo con el escaso apoyo plástico y textual que se po- see (M.P.García-Gelabert). Y otro aspecto, tratamos de aclarar el nexo del caballo con el Más Allá y la heroización ecuestre (J.M.Blázquez¹).

¿Cuándo el caballo como animal de monta es utilizado por los miembros de las tribus de la vieja Iberia? Diversos historiadores se han ocupado del tema, y ahora sabemos que, por lo menos hacia el siglo VIII a.C., los varones miembros de la cultura europea de los Campos de Urnas eran en parte jinetes, y a través de sus migraciones fluidas, nunca invasiones, la equitación se extendió más entre los peninsulares con los que entraron en contacto. Pero igualmente hay que valorar otros argumentos materiales que sitúan

1. Agradezco a la Dra. G. López Monteagudo, del CSIC y a los profesores J.M. Abascal, de la Universidad de Alicante, L. Ruiz, F. Lara Peinado, de la U.C.M., F. Marco y F. Beltrán de la Universidad de Zaragoza, las importantes indicaciones prestadas y la bibliografía, incorporadas al texto. 
más o menos simultáneamente la presencia en el sur de caballos de tiro e incluso de monta: en las estelas del suroeste, cuya cronología, sin absoluta certeza, comprende un arco entre los siglos IX, VIII e incluso el siglo VII a.C., se hallan significados carros, a los que debían engancharse dos cuadrúpedos. Por el absoluto esquematismo de los trazos incisos de los grabados no es posible precisar si los animales de transporte eran équidos o bóvidos. Aunque es más probable que como fuerza de arrastre para unos carros utilizados en la exaltación mortuoria de determinada persona, a través de la figuración en una estela funeraria de sus elementos guerreros, sea más idóneo un par de corceles. Tiro más noble, que uno de bueyes, éstos tradicionalmente más enraizados con el trabajo del campo y el transporte bruto de mercancías o géneros agrícolas. Concerniente a los carros significados en las estelas, paralelos y sus derivaciones, así como acerca de los diversos vehículos, de cronología similar y más moderna, se escribe en otro lugar de este artículo -J.M. Blázquez-. En la necrópolis orientalizante de inhumación/cremación de La Joya (Huelva), en la tumba de inhumación $n^{0} 17$, junto a la pared norte y cerca del lado oriental, fue encontrada la parte metálica de un carro entre dos ánforas en forma de saco. Otro posible carro, a través éste de escasos restos, fue aislado en la tumba $n^{\circ} 18$, al parecer de incineración, de la misma necrópolis (Garrido, Orta, 1978, 124-128) (vid. infra). Respecto a la datación del cementerio, en el que se enterraron grupos oligárquicos tartésicos, conectado con las poblaciones de los cabezos de Huelva (San Pedro, -sobre todo con este-, Molino de Viento, La Esperanza, Mondaka, El Conquero), sus investigadores, en un párrafo, la fijan desde fines del siglo VII hasta la segunda mitad del siglo VI a.C. (Garrido, Orta, 1978, 200), y un poco más adelante exponen que “... no obstante para el área de hábitat próximo poseemos elementos que nos retrotraen al siglo VIII a.C. o quizás antes" (Garrido, Orta, 1978, 210).

Como indicamos atrás, acerca de los carros aporta datos J.M. Blázquez, no obstante trazamos aquí y allá unas breves anotaciones a manera de introducción. El uso del carro con connotaciones ideológicas, como soporte de clara superioridad sobre el resto de la población, está extendido en todas las civilizaciones a partir del Bronce Reciente desde el Próximo Oriente hasta Occidente (Quesada, 1997, 157-164). Constituye el carro una suma de las cualidades técnicas, en este caso de los subordinados de las estirpes peninsulares, que avalan la especialización y por extensión la multiplicidad social.

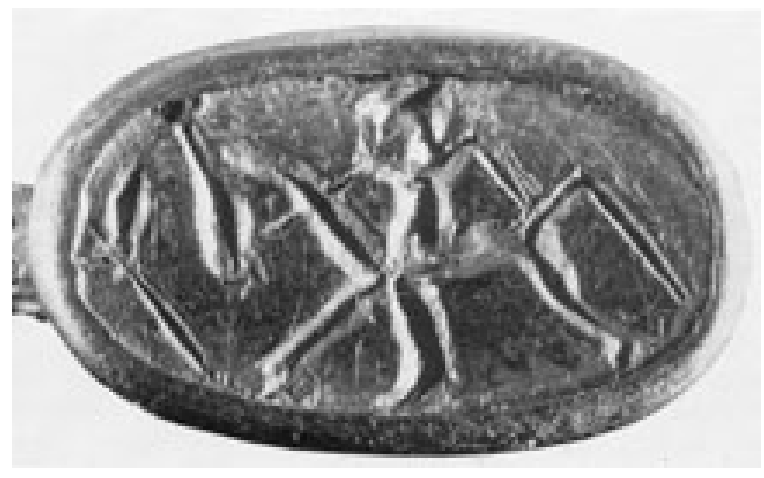

Figura 1: Anillo de oro constituyente del tesoro de La Aliseda, Cáceres (Foto Almagro-Gorbea, 2005, 63, fig. 1).

Supone conocimientos avanzados y en distintos campos. De un lado exige para su diseño de una tecnología aunque sólo sea empírica matemática y de física; por otra parte, es necesaria una cierta experiencia y una cierta destreza en la manipulación de los metales, ya que combina madera y metal. Compone, al mismo tiempo, una obra que requiere de un convenio social, pues están implicados artesanos de muy distintas profesiones: herreros, orfebres, carpinteros.

Sigamos, otro elemento, que autoriza la teoría acerca de la presencia del caballo en el sur en fecha temprana, es un anillo de sello en el cual se representó un jinete (Fig. 1). Es componente del tesoro de La Aliseda (Cáceres), datado hacia finales del siglo VII a.C. (Almagro-Gorbea, 1977, Lám. 30). Las joyas son de importación próximo oriental ¿Siria?, y pertenecieron, según los datos aportados por la investigación, a un personaje femenino de alta dignidad, mas la iconografía, en este caso solamente del sello, entra dentro de la lógica hipotetizar que fue acorde con las preferencias de los que lo adquirieron, porque pudieron ser propietarios de caballos; aunque en el supuesto de que esta hipótesis, sin base firme, no se acercara a la realidad, tampoco tiene mucha importancia a los efectos de nuestro estudio, pues ya atestiguamos el caballo en el mismo cuadrante suroccidental, en el ámbito indígena enriquecido de la necrópolis de La Joya, y antes en las llamadas comúnmente estelas extremeñas.

Bien, una salvedad, analizando la composición de los grupos humanos desde el siglo VIII a.C. hacia dataciones más bajas, tanto los del sur como los que penetraron por los pasos pirenaicos,-éstos asentándose comenzaron por fusionarse con los naturales en el noreste y valle del Ebro, y posteriormente en marcha hacia la Meseta siguió el mismo ritmo de mestizaje-, ha de argumentarse, con una cierta seguridad, que el caballo no debió ser utilizado por ellos para 


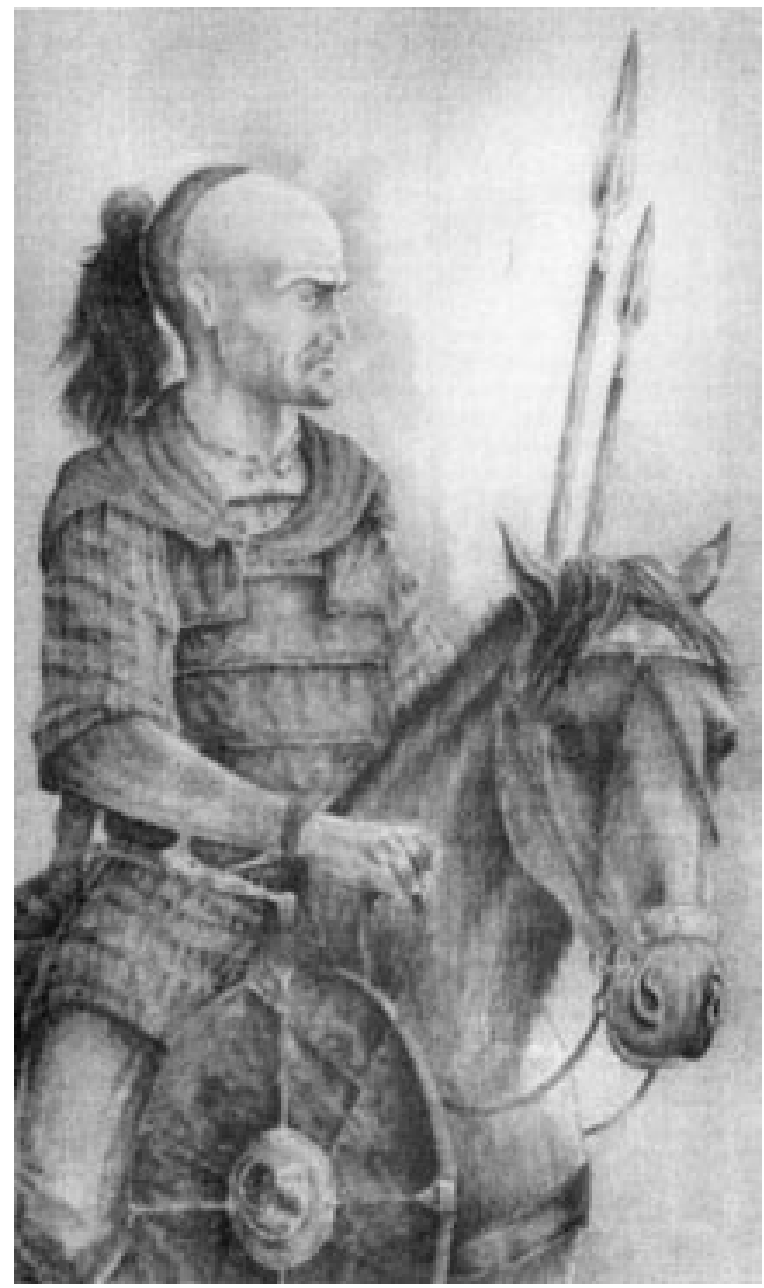

Figura 2: Jinete vacceo del siglo II a.C. (Foto Sanchez Moreno, 2005, 152, fig. 4, recreación del autor).

fines militares con jerarquía evidente. No tuvieron ni las tribus de tinte orientalizante, ni las de tinte indoeuropeo un soporte político, económico y social estructural, a la vista de los testimonios arqueológicos, como para soportar una sociedad considerablemente estratificada en la que pudiera estar imbricado un tipo de ejército netamente diferenciado en caballeros dirigentes e infantes dirigidos. Otra cuestión es que en sus bandas de combate marcharan mezclados jinetes con infantes sin un aparente, sólo aparente, orden; mas en contienda sin concepto nítido de escalas de valores sociales, si bien sí militares, la posesión de un caballo, en la mayor parte de los tiempos, implica ya supremacía.

No continuamos con argumentos de apoyo a los períodos en lo que se constata el caballo domesticado plenamente y utilizado como montura, porque sería largo, porque este campo ya ha sido investigado y sobre todo porque no es la idea conductora que nos guía. Así pues vamos derivando hacia ella. Concretándonos a los enfrentamientos bélicos, la lucha a caballo se experimenta con mayor pujanza, y gradualmente se constituyen los batallones de caballería, siempre contemplando a la misma como compuesta por infantes a caballo, en el elemento más apreciado en los ejércitos, a partir de la época en la que la evolución de las etnias prerromanas es bien consistente, aproximadamente desde el siglo $\mathrm{V}$ a.C. en adelante (pero esto no es una afirmación terminante). En aquellos tiempos la selección de razas equinas, su mejora, la doma, el adiestramiento específico para la guerra, permitieron someter a los caballos a las muy diversas situaciones adversas y esfuerzos que conlleva una lucha armada, que no eran comparables a los de otras circunstancias [“...va a encontrarse con el hombre armado. El se burla del miedo, y no teme; tampoco la espada lo vuelve atrás" (Libro de Job)]. Y aún así, y según F. Quesada (1977, 186), la caballería constituirá un arma decisiva en los combates, como fuerza de ataque por sorpresa y/o para la rapidez de entrada en liza, sólo desde el siglo IV a.C., y fundamentalmente desde la II Guerra Púnica. Es decir en una de las épocas culminantes, la última, de desarrollo de los linajes hispanos, sean los del litoral sean los del interior, aunque pronto truncado el dicho desarrollo por la impronta violenta romana.

Por tanto, y siempre valorando la teoría de F. Quesada (1977, 186), conjeturamos la realidad acerca de que la caballería guerrera comienza a ser significativa a partir del siglo $\mathrm{V}$ a.C.; porque además de lo indicado en el párrafo anterior, y es importante, en general, a medida que discurren los años, los siglos, se complejizan las sociedades, las culturas, y parte de sus miembros se enriquecen más que otros, teniendo pues acceso a la cría y utilización de ganado caballar, entre otros bienes, que se convierten en una de las muestras externas de diferencia social (Fig. 2). Este grupo escogido, que poco a poco va destacándose nítidamente, se hace presente en las regiones iberas en sus a veces fastuosos monumentos funerarios, decorados con escenas escultóricas en las que participan soldados a caballo, como en el heroon de Obulco (Porcuna, Jaén), fechado en la segunda mitad del siglo $V$ a.C. Con respecto a la escultura, el área indoeuropea no la aporta apenas en piedra, e incluso ni siquiera se levantan superestructuras funerarias destacables, que resalten en el paisaje de los cementerios; es así porque por el ritmo interno de la mentalidad reinante en sus tribus, nunca fueron proclives a señalar con esplendor los sepulcros; $y$ en sus santuarios no ofrecieron 


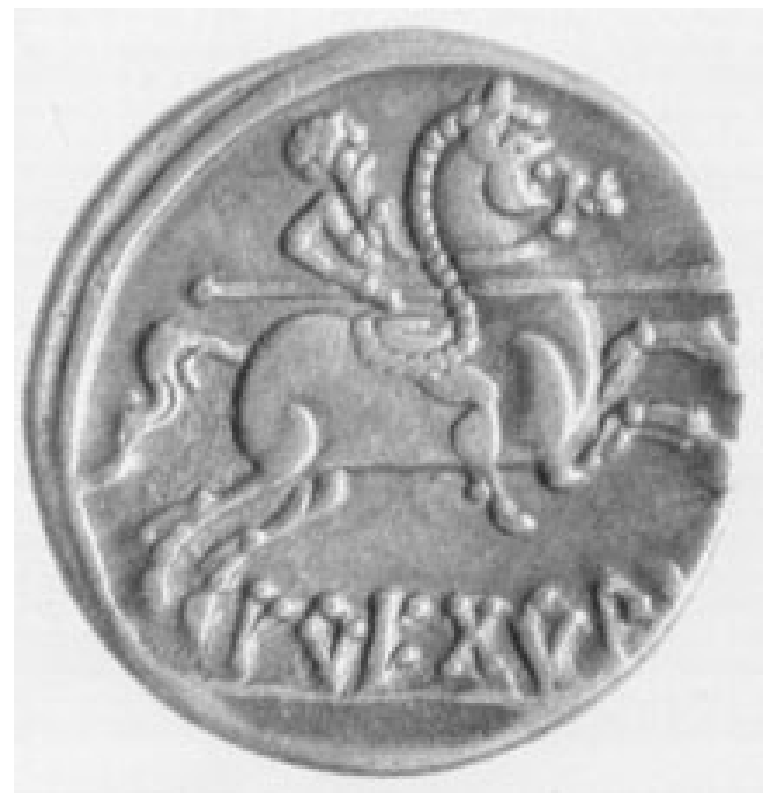

Figura 3: Jinete en un denario de la ceca de Arekoratas. Luzaga, Guadalajara (Foto Sánchez, Moreno, 2005, 158, fig. 8).

los fieles exvotos no perecederos representando figuraciones antropomorfas o zoomorfas. De momento apenas constan, entre otras razones porque sus lugares sacros suelen situarse al aire libre, y cualquier vestigio llamativo fue abocado a desaparecer a través de siglos y siglos de hallarse expuesto a las miradas profanas y al hurto de cualquier transeúnte. Pero no obstante es bien apreciable la importancia de los nobiles equites celtas en otras artes plásticas, como en la orfebrería. Omitimos las piezas notables existentes para no dilatar excesivamente la introducción, ya de por sí extensa.

De una forma $u$ otra el resultado es que la asociación jinete-caballo fue tan completa y se halló tan estrechamente unida en las prioridades de las tribus de Iberia que comprobamos, ciñéndonos en primer lugar a la faceta religiosa de la sociedad, cómo los hispanos, en este caso los iberos, -incluso peregrinos celtas o de otras procedencias étnicas, atraídos por la fama de tal o cual lugar sagrado-, acuden a los santuarios panibéricos donde reciben culto aquellos dioses de nombre y faz desconocida, que protegen a las caballerías y por extensión a ellos que las montan; son dioses a los que los hombres prometen para conseguir, para inclinar hacia si la buena disposición divina, u otorgan después de recibido el beneficio, unos para nosotros indeterminados sacrificios, aderezados con oraciones cantadas o salmodiadas, música, movimientos rítmicos rituales, genuflexiones. Dichos sacrificios, a más de por los ingredientes indicados, debieron estar constituidos, de manera general y especulativa, por ofrendas de vegetales, de animales y/o de líquidos, quema de sustancias aromáticas en hogueras sagradas, ofrendas de piezas en bulto redondo, relieve o incisión de los propios animales, sobre metal, piedra, madera, etc. Acerca de las ofrendas y actos litúrgicos no hay otra opción que la de teorizar sobre apoyos muy débiles, y por tal medio acercarnos a una cierta realidad, que nunca sabremos si efectivamente lo es, porque del complejo ceremonial que por lo menos en algunas solemnidades debió celebrarse, y de los ritos de petición y ofrenda comunes ¿dirigidos por hombres santos?, apenas quedan diversos objetos perennes, -exvotos, fragmentos cerámicos, huesos de animales, residuos de hogueras-, y como infraestructura alguna pileta, alguna cavidad, algunos canales tallados en la roca de base, algunas hornacinas, algunos bancos, apenas ciertos grabados y pinturas en la roca toscamente preparada al efecto y poco más. Salvo indicación expresa, aplicamos los contenidos rituales materiales reseñados a los santuarios que reflejamos en texto. Los exvotos los pudieron obtener los fieles en los establecimientos anejos al lugar sacro o los produjeron ellos mismos, como debió ser el caso de las placas/bloques de Luque (Córdoba), con grabados o relieves figurando caballos.

En segundo lugar y en el espacio profano, civil, social, económico en fin, el caballo tuvo un protagonismo que no se cuestiona, y es de todos conocido un testimonio preciso, es el relativo a las monedas de una buena parte de las cecas autóctonas con el tipo del "jinete ibérico" de los reversos, sosteniendo una lanza, aunque a veces lleva espada u otras armas (Fig. 3); y por supuesto, tomaron como modelo iconográfico al oligarca, al gran guerrero, en apoteosis, sobre su cabalgadura. En el anverso de las monedas de la serie dicha del "jinete ibérico" suele figurar la cabeza de un varón, acerca de la cual M. Almagro-Gorbea $(2005,86)$ es partidario de que compone un todo con el jinete, personificando una divinidad, "la iconografía con cabeza masculina y el Heros equitans de las acuñaciones hispánicas, debe representar a la divinidad local del grupo étnico y/o de la población correspondiente, que sería su Héros Ktístes o epónimo, más que un dios de carácter supra-regional o pancéltico..." Esta iconografía creemos es determinante del conservadurismo hacia los hechos heroicos y caballerescos, hacia la vieja realidad hispana, ya en situación de verdadero caos y en vías de desaparición, al menos exterior, a causa 
de la civilización romana, ésta con fortísimo poder de absorción y con alto impulso por ser la de los conquistadores. En este sentido es legítimo imaginar que la admiración, que el recuerdo de las gloriosas gestas épicas de los antepasados heroizados, que fueron las de la tribu, y conocidas por transmisión oral, y en cierta manera reflejadas en sus descendientes, constituyeran, para los pueblos hispanos nostálgicos, un punto de apoyo en la situación de sometimiento actual. Y que esta coyuntura haya sido utilizada por los dichos descendientes para potenciarse, con respecto a los suyos, en la función política al lado de Roma.

Sobre esta iconografía hay, entre otras, dos líneas de investigación y de interpretación diferentes y desde diversas perspectivas, en cuya controversia no participamos activamente. M. P. García-Bellido (1993) opina que es creada por la organización fiscal romana, M. AlmagroGorbea (1995a; 1995b), con el que estamos de acuerdo, es partidario de que germinó en el caldo de cultivo que suponía la supremacía de la casta privilegiada autóctona, y que aún en una sociedad controlada por Roma, es la imagen de la libre primitiva, un guerrero a caballo; esta alta clase que en los nuevos tiempos en parte confraternizó directamente con los magistrados procedentes de la Metrópoli, confraternizó directamente con cualquier persona relacionada con Roma que brillara en la sociedad, entre otros publicani, negotiatores; esta alta clase que supo promocionarse en el nuevo sistema, rigiendo las civitates y manteniendo, quizás, parte de sus antiguas posesiones; en resumen, conservando entre los suyos (menos entre los refractarios al yugo romano) un concepto de rango similar al de antaño; pero eso sí, es inevitable que tiendan a ir adquiriendo en principio una apariencia romana, más adelante se aculturan casi totalmente. Así lo desea Roma para su mayor tranquilidad, y así lo desean ciertos segmentos de entre estos notables, porque es el único medio de continuar con el liderazgo (controlado por los gobernadores enviados por la Metrópoli).

\section{EL CABALLO DE IBERIA EN LOS TEXTOS GRECOLATINOS}

Es emblemático del protagonismo del caballo selecto de monta entre las tribus de Iberia un arcaico mito lusitano, que según J. Bermejo (1982, 99), al que seguimos, "se ha conservado claramente a través de las fuentes literarias greco-latinas... pues la comparación de todos sus ele- mentos con los de otros mitos griegos confirma plenamente este carácter, que, por otra parte, el propio origen del pueblo lusitano ratifica... ". Se trata del mito de las yeguas de la región del Tajo preñadas por el viento, transmitido por varios autores grecolatinos: "se sabe que en Lusitania, cerca de la ciudad de Olisipo a orillas del Tago, las yeguas vueltas de cara al viento cuando sopla el Favonio reciben un soplo vital y conciben así y paren potros velocísimos, pero que no viven más de tres años..." (Plin., NH VIII, 166. Sobre dicha cuestión vuelve el Naturalista en XVI, 39,93. Y también: Varr., r. II, 1,19. Verg., Georg. III, 271-279 y su comentarista Servio Gramático, Ad Georg. III, 273. Col., Rust. VI, 27,7. Sil. Ital., Pun. III, 379-381. Just., Epit. XLIV, 3, 1, tomado de Pompeyo Trogo).

No es viable desarrollar aquí, por razones de espacio y contenido, los detalles recogidos por los textos grecolatinos acerca de las razas equinas concretas de Iberia. Además que unas y otras descripciones aportan una dudosa visión del caballo hispano, siempre excesivamente parcial, mas apuntamos breves líneas sobre una, tendente a resaltar, aún más, cómo escritores de uno $u$ otro tiempo recopilaron datos precisos acerca de los caballos de Iberia, síntoma de que su notoriedad franqueó los siglos. En el Corpus Hippiatricorum Graecorum, compuesto en la Edad Media (se compilan trabajos sobre todo de autores griegos de siglos anteriores), acerca de cuya veracidad no entramos, puede leerse la descripción anunciada: "Los caballos hispanos son de gran alzada, buenas proporciones, posición erguida, cabeza hermosa. Tienen la espalda y el lomo hendidos. Sus ancas no son hermosas. Como caballos de viaje son duros, no enflaqueciendo. Son valientes y veloces, no haciendo falta que se los espolee. Son de buen natural desde su nacimiento hasta edad completamente adulta, pero más tarde malos y mordaces" (I, 373, 2).

La raza ligeramente descrita no abarca las peculiaridades de ese pequeño corcel hispano, cuya cuna fueron las montañas de las actuales Galicia y Asturias, el asturcón, el cual, entre otras cualidades, se distinguía por su paso portante o ambladura, es decir movía simultáneamente pie y mano del mismo lado del cuerpo en idéntica dirección; y este paso era tan cómodo que, como indica Plinio (NH VIII, 16), se atendió a que otros caballos lo adoptaran. Los asturcones gozaron de un enorme predicamento entre los romanos, como evidentemente entre los propios hispanos. Por Suetonio (De vita Caes., Nero. XLVI,1), refiriéndose a un sueño perturbador de Nerón poco antes de su muerte, se sabe que su caballo favo- 
rito era un asturcón. Esta raza fue generosamente definida en los textos, de los que extraemos la bella descripción de Marcial (XIV, 199): “...este caballo pequeño astur que galopa rápidamente al son del compás, viene de la gente rica en oro". Según Silio Itálico (Pun. XVI, 583) uno de los premios que se distribuían después de los juegos circenses consistía en un tiro de corceles asturianos. También escribe que el caballo asturiano no sirve para la guerra (Pun. III, 332-355). Y en párrafos anteriores celebra a un caballo astur de nombre panchates, que era poco vistoso, pequeño, blando de boca, muy rápido y con manchas blancas en los corvejones y en la frente (Pun. XVI, 348-353). Otra raza criada en las montañas asturianas era la de los tieldones, mencionada por Plinio (NH VIII, 166).

De entre los caballos hispanos, asturcones, tieldones, de diferentes razas o mestizos, es bien sabido que el caballo de silla (la usada por lo menos hasta el siglo III a.C., el ephippium, consistía en una especie de manta de lana o cuero, almohadillada o no, sujeta mediante una cincha ancha y un pretal) (Fig. 4), y concretamente el de guerra, hemos de reiterarlo a fuer de ser excesivamente insistentes, era el animal eminente de los soldados de las tribus de Iberia, tanto de los de las de procedencia indoeuropea como de los de las iberas; fue el representativo de los guerreros de élite, es decir de los guerreros dirigentes, de los guerreros pertenecientes a la clase social privilegiada, fue el animal con más alto valor económico y social para los peninsulares y más, su

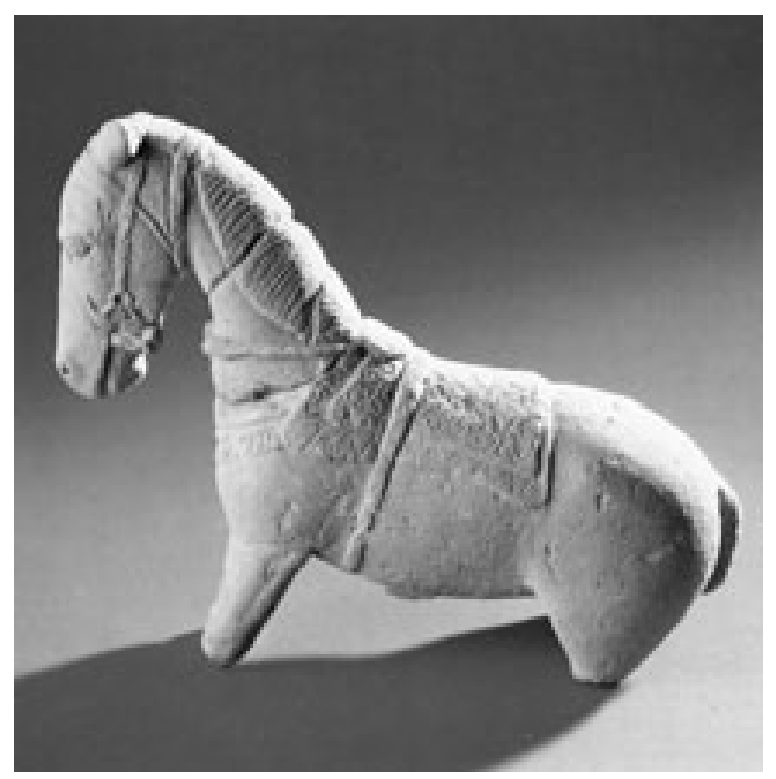

Figura 4: Exvoto en piedra de un caballo, procedente del santuario de EI Cigarralejo, con la característica silla de montar ibera (ephippium) (Foto F. Quesada,1997, 193). compañero fiel inmediato y devoto, devoción que era mutua, como bien escribe Justino (Epi. XLIV, 2,5):"Es un pueblo (el hispano) de viva agilidad y espíritu inquieto y para la mayoría son más queridos sus caballos de guerra y sus armas que su propia sangre". Fue potestativo de aquéllos que detentaban el suficiente dominio, la suficiente autoridad como para lograrlo y mantenerlo, para poseer las propiedades necesarias para su cría o incluso para llegar a acaparar, por la fuerza de su propio poder, los probables terrenos colectivos, lo cual es elemental. Contribuía el caballo, aunando el hombre su propia fuerza con la de él, a incrementar la energía, la dureza, la eficacia en el ataque de los que formaban, como jinetes, parte de los ejércitos tribales, que ya, en principio, repetimos, eran los más destacados miembros de su estirpe. $Y$ esos jinetes ilustres no tenían empacho en descabalgar y luchar junto a la infantería, colocándose al frente, con las mismas tácticas y más éxito que sobre montura, porque la carencia de estribos era un impedimento grande para la buena resolución de un acto bélico. Así se lee, entre otros, en el texto de Livio (XXIX, 2,13), relatando la rebelión del año 205 a.C.de los ilergetes y ausetanos y la muerte del ilergete Indíbil, cuando la figura carismática de P.C. Escipión fue sustituida en la recién comenzada conquista de Iberia por las de otros generales (L. Léntulo y L.Manlio Acidino): “... No habrían los bárbaros resistido un tan vigoroso asalto si el mismo reyezuelo Indíbil, con los jinetes desmontados, no se hubiera lanzado delante de las primeras tropas de infantería..." La costumbre de combatir a pie los jinetes está igualmente recogida por Diodoro $(\mathrm{V}, 33,5)$ y Estrabón (III, 4,15-18), refiriendo éste como dos hombres montados en un mismo corcel al entrar en batalla uno descabalga. Aún en tiempos de César subsistía el combate a pie de los jinetes (Bh. XV, 1), y desde luego no cabe duda de que debe pensarse, como indicamos más arriba, en infantería montada que comparte una táctica común con los infantes propiamente dichos. Este modo de combatir está atestiguado muy temprano en el heroon de Obulco, en uno de cuyos grupos, mutilado, como el resto, un equite, combate a pie y, por su postura frente a un enemigo caído, -según reconstrucción de I. Negueruela (1990, 302-303)-. Va pertrechado con un armamento muy específico de las tribus interiores [espada envainada "las espadas de los hispanos, manejables por lo cortas y con punta, pues estaban acostumbrados a atacar al enemigo clavando más que dando tajo" (Liv.XXII, 46). "Las espadas iberas podían herir lo mismo de punta que de filo" (Plb. III, 113, 6); caetra (el escudo pequeño oval 
de las poblaciones hispanas), y faleras (discos protectores)].

Constituyó uno de los muchos topoi para los autores grecolatinos que escribieron sobre Iberia la alta cantidad y calidad de los caballos que se criaron en estado salvaje en yeguadas y en tropillas en los montes, en las praderas, que se criaron domesticados en los campos comunales (entre otros Str. III, 4, 15). Y bien, constituyó un tópico sí, pero verdaderamente se basó en la realidad. Las alusiones textuales a los caballos, en cuanto a territorio, o bien engloban la península sin particularizar, o bien se refieren más específicamente a las regiones en las que Roma tuvo que lidiar más intensamente con los nativos durante la conquista de Iberia, esto es las dos mesetas y Lusitania (dejamos fuera de esta disquisición la guerra, muy cruenta, contra las tribus de la cornisa cantábrica por las tropas de Augusto (29-19 a.C.), porque no forma un continuum con la ocupación del resto peninsular). Estas afirmaciones, que además encontramos en Martín, Padilla $(1997,479)$ y en Bendala, Quesada $(1995,53)$, no quieren decir, por una parte, que los iberos no ofrecieran resistencia a las armas romana, si la ofrecieron, y por otra, que entre las tribus iberas fuera más restringido el uso del caballo, no fue más restringido. Lo innegable es que aquellos tratadistas que escribieron sobre Iberia, lo hicieron con mayor amplitud acerca de los referidos enfrentamientos Roma/las dos mesetas/Lusitania, por la extraordinaria dureza que conllevó el tener que hacer frente a los pueblos de raigambre céltica, a partir de las campañas del cónsul M. Porcio Catón en el año 195 a.C. (Liv. XXXIII, 43; XXXIV, 8, 4, ss.); a las crueles sublevaciones de los celtíberos entre los años 154-133 a.C., a las de los lusitanos (147-139 a.C. Efectivamente las guerras en las zonas indicadas resultaron sumamente crueles para Roma (no menos para los hispanos) a causa de la difícil orografía, del clima, de los alimentos y del sistema de combate legionario, no adecuado al relieve, y aún peor adecuado a la estrategia combativa de los naturales, hasta el punto que cuando se trataba de enviar tropas de refresco, los jóvenes reclutas tenían terror en viajar hacia los campamentos de Hispania, sabiendo del poder bélico de los celtíberos, lusitanos, carpetanos, etc. (Plb. $35,3,6)$. Incluso determinados mandos, tribunos y legados, trataban de negarse a participar en las contiendas meseteñas (Liv., per. XLVIII), en las "guerras de fuego" (Plb. XXXV, 1. D.S. XXXI, 40), cuyos participantes combatían de noche y de día, con frío o con calor, resistiendo a la fatiga. Y como fue mayor el desarrollo de la literatura al

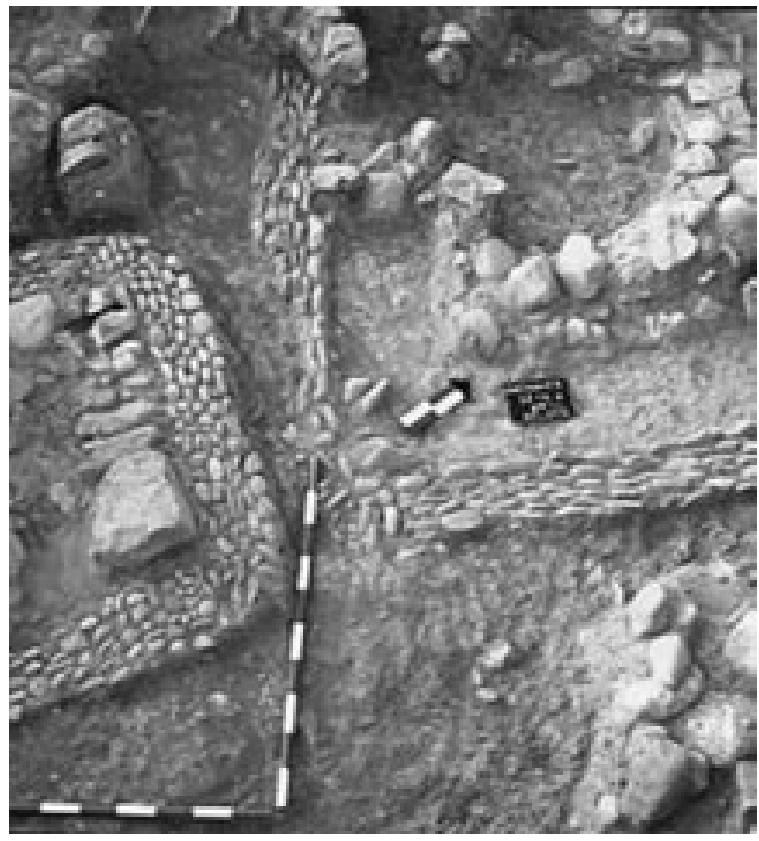

Figura 5: Necrópolis del Estacar de Robarinas, vista parcial.

respecto de la guerra en los territorios indicados, fue mayor la información indirecta, por lo que atañe en este trabajo al caballo. Mas el efectivo silencio que para el área ibérica existe en los textos se compensa con la mayor abundancia de información en la plástica, en más alto número que en las zonas interiores, aunque en éstas, ya se apuntó, no falta completamente en diversos soportes. Además, en las necrópolis iberas se han hallado restos óseos de équidos, menos de los que hubiera sido de desear, y más que en las necrópolis del área indoeuropea; hay que tener presente que el sacrificio de este animal debió representar una gran pérdida para la familia del fallecido, y que exclusivamente podrían permitírselo aquéllas que dispusieran de un cierto número y holgura económica suficiente. Y generalmente, en un ambiente en el que domina casi totalmente la cremación, los caballos inmolados no fueron quemados; sus restos se sitúan con los restos del ajuar, más concretamente entre los del armamento de soldados cremados, cual es el caso de una hemimandíbula inferior derecha completa, y piezas dentarias del mismo equus caballus, recuperadas entre las tumbas XVII-XVIII-XX, que componen un conjunto sepulcral familiar, de la necrópolis de El Estacar de Robarinas, al servicio de la ciudad ibero romana de Castulo (Linares, Jaén), datada aquélla entre finales del siglo $\checkmark$ y mediados del siglo IV a.C. (García-Gelabert, 1987, 86-87, Lám. XVIII, b) (Fig. 5). Por cierto, y al respecto de los caballos sacrificados, no creemos estar muy desacertados si imaginamos que 


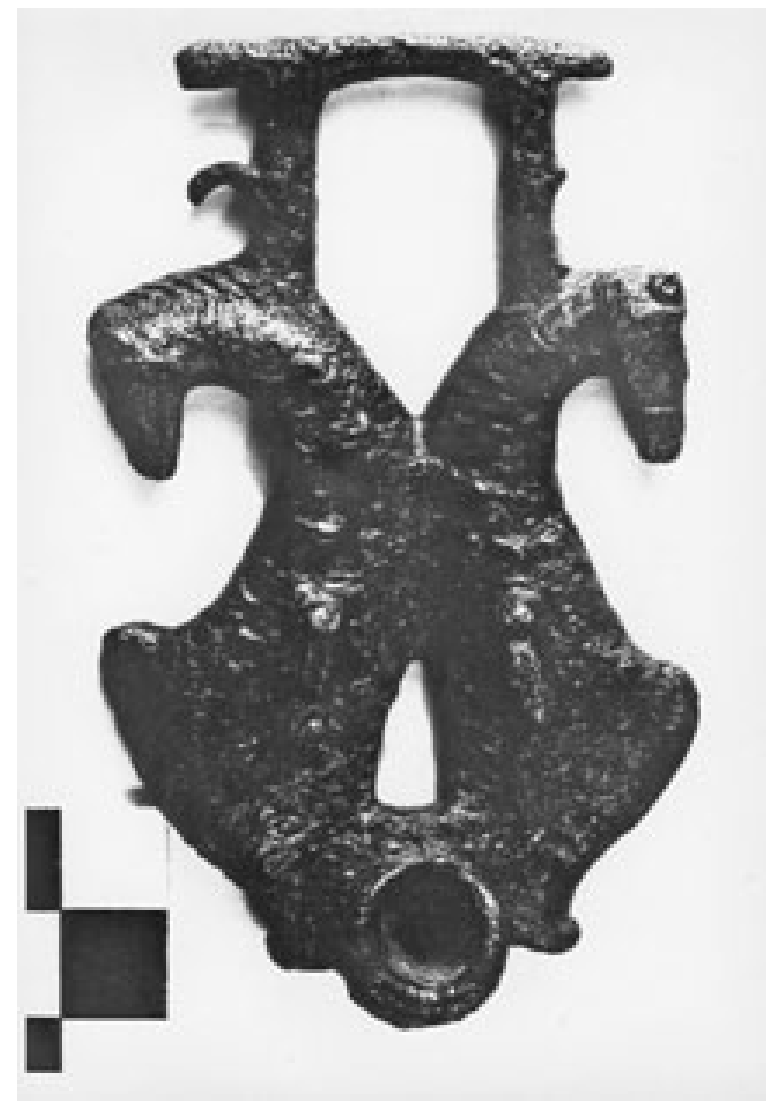

Figura 6: Cama de bocado de caballo de Castulo (Foto J.J. Urruela, 1984, 43, 51, Fig. 22, Lám. XXX,2),

una parte de la carne o toda se consumiera en las comidas rituales funerales, pero existe una duda, los huesos, por lo menos los analizados por nosotros, no atestiguan fuego, luego la carne no era asada, así pues la carne ¿se cocía, se maceraba, etc.? no podemos pensar que se consumiera cruda. Y la mejor porción, en cuanto al concepto de que en la cabeza reside la fuerza anímica de un ser, se debía ofrendar al ánima o a aquella parte del ser humano desaparecido que según las creencias ancestrales iberas sobrevivía a la muerte (no conocemos nada al respecto de cómo concebían la inmortalidad, si es que la llegaron a concebir de alguna manera: si absoluta, si relativa, si inmortalidad del cuerpo en el reino de los muertos, si inmortalidad de la supuesta parte espiritual del hombre en el Allende o en la sepultura, etc.). Sobre la inmolación de caballos en el ámbito funerario vid. infra.

En los enterramientos se encuentran del mismo modo arneses, muy escasos, como entre otras en la dicha necrópolis de El Estacar de Robarinas, y siempre asociados a armas (Blázquez, Remesal, 1979, 393. García-Gelabert, 1988,159). Uno de los bocados recobrado en la campaña de excavación del año 1976 pudo estar adornado al menos con una cabecita de caballo, ésta recuperada en las cercanías de la zona donde estaba el tal bocado (Blázquez, Remesal, 1979, 393), aunque por la lógica simetría compositiva serían dos las cabecitas. Por cierto, los bocados, muy poco evolucionados, debían constituir un verdadero suplicio para el animal. La realización de cabezas equinas en los bocados, o en otros de los arreos del animal tiende a ser básico, instintivo, como en la cama de bocado procedente de Cancho Roano (Zalamea de la Serena, Badajoz), datada en principio en el siglo $\mathrm{V}$ a.C., con dos prótomos de caballo (Quesada, 2005, 18, Fig. 14); véase, igualmente en los arreos fabricados por romanos o por indígenas romanizados, el caballo estaba presente, y un ejemplo es la cama de bocado, hallado en el interior de una cisterna, cuando ésta dejo de utilizarse, situada en la acrópolis de Castulo (Urruela, 1984, 43, 51, Fig. 22, Lám. $X X X, 2)$. Su ornamentación consiste en dos delfines que unen sus bocas a la anilla del parafrenos y cuyas colas acaban en dos cabezas de caballo, en las que pueden apreciarse las riendas (Fig. 6). Los delfines siempre fueron animales relacionados con la Diosa Madre cartaginesa Tanit, pero esta pieza se halla cronológicamente muy lejos del ambiente púnico que impregnó a las remotas culturas iberas. $Y$ no somos partidarios de una perduración oretana decorativa en plena época bajoimperial, a pesar de que muchos otros rasgos, pero de distinta índole, se mantuvieron más o menos adulterados, mestizados, a través de los tiempos. Y en el elemento en cuestión no parece que haya un contenido profiláctico, si nos atenemos a la idiosincrasia romana articulada con la religión propia. Otro aspecto distinto sería si la iconografía del objeto hubiera sido dictada por una creencia determinada, concebida en el seno de alguna de las religiones orientales, que recogiera ecos de las tradicionales diosas de la fertilidad, entre las que se cuenta Tanit, esas religiones de las que, sobre todo durante el Imperio, fueron practicantes ciertos sectores de las élites y del pueblo. Pero la verdad es que se trata de una argumentación excesivamente frágil. Según su descubridor, y atendiendo al lugar en que se encontró, la pieza no puede ser anterior al siglo III ni posterior al siglo $\mathrm{V}$.

Arreos, asimismo, se han encontrado en las tumbas más relevantes de las necrópolis celtibéricas como, entre otras, en las de Aguilar de Anguita (Guadalajara), Alpanseque (Soria) (Almagro-Gorbea, 2005, 71), etc.

Bien, retornando al hilo conductor en cuanto a la calidad y cantidad de los caballos, en toda 
Iberia se produjeron óptimos, y no ha lugar a particularizar por regiones, porque la cría caballar debió extenderse a todos los ámbitos peninsulares. Bajo ningún concepto es una afirmación gratuita, las aportaciones de la escasa epigrafía y las indirectas de los textos, como las que siguen, más valiosas que las frases hechas, indican tal realidad. En los inicios de la presencia romana en Iberia después de la batalla de Baecula (208 a.C.) Escipión, luego de apoderarse del campamento cartaginés, distribuyó parte del botín entre los jefes hispanos que habían formado en sus filas:"mandó a Indíbil que de la gran cantidad de caballos capturados eligiese los trescientos que más le agradasen" (Liv. XXVII, 10, 1). En los sangrientos episodios de la conquista por Roma de las zonas interiores peninsulares, he ahí como la administración romana entre las indemnizaciones de guerra que impone a los nativos se hallan caballos de batalla (140-139 a.C.):"Los numantinos y los termesios enviaron legados a los romanos para tratar la paz, y la obtuvieron con estas condiciones: una y otra ciudad entregarían a los romanos trescientos rehenes, nueve mil sagos, tres mil pieles de buey, ochocientos caballos de batalla y todas las armas..." (D.S. XXXIII, 16), al especificar la índole concreta de los caballos, de batalla, está implícita la existencia de animales destinados a otras distintas tareas. Así es, a más de los caballos para el transporte de personas, dirigidas hacia la caza, guerra, o cualquier actividad distinta, debe pensarse en la existencia de otros de labor, de carga y de tiro, ciertamente de menor calidad, y mulos, yeguas, asnos, destinados a transportar mercancías, o a sus dueños, campesinos, artesanos, comerciantes. Sobre asnos o mulos, conducidos en reata o individualmente, cuando el carro aún no había sido asimilado, se han acarreado en el mundo rural desde tiempos muy arcaicos (aún ahora) cargas de leña, cereales, hierba y todo tipo de productos recolectados, cultivados o silvestres, o bien artículos industriales. Y siguiendo con las conversaciones entre numantinos-termesios y romanos, en las contiendas de los años 140-139 a.C., el tratado no se llevó a efecto, porque el honor de los mismos, como hombres y como soldados, produjo que se opusieran contundentemente a entregar las armas. En nuevos párrafos se alude al enfrentamiento de las tropas ocupantes con potentes batallones de jinetes hispanos, cuyos corceles son velocísimos (App., Iber. LXI-LXIII, al referirse en los años 147-146 a.C., a los encuentros entre las legiones y los hombres de Viriato). Naturalmente que las monturas eran veloces, sí, pero la verdad es que a los romanos en la tierra peninsular, empeñados en las "guerras de fuego" de la conquista, salvo la fertilidad de la tierra, la riqueza minera, la de las salinas y la de las pesquería, éstas levantadas en parte por los fenicios y cartagineses, todo lo demás les parecía pavoroso y peligroso en grado máximo, principalmente: a) sus hombres veloces "como el viento" (Plu., Sert.XIII, aludiendo a las tropas hispanas al mando de Sertorio); b) sus hombres salvajes, entrando en combate "haciendo gran estrépito y clamor, y llevando largas cabelleras...sacudiéndolas para infundir pavor..." (App., Iber. LXVIILXIX, refiriéndose a los lusitanos, mas haciéndolo extensivo a "todos los bárbaros". También Liv. XXII, 18, 2; XXIII, 26; XXIII, 27; 28, 1; XXVIII, $22)$; y si estos soldados eran jinetes, atacaban de la misma forma, es decir con fortísimo ímpetu, y después descabalgaban "la infantería llevaba también mezcladas fuerzas de caballería; los caballos están habituados a escalar montañas y a flexionar rápidamente las manos a una orden dada en momento oportuno" (Str. III, 4,15), igual que reseñamos líneas atrás lo realizaron Indíbil y sus jinetes (Liv. XXIX, 2) y otros. Acaso el mismo pánico de los legionarios forjaba que sus sentidos duplicaran la velocidad y fiereza de hombres y bestias; c) sus hombres traidores, como Abelux de Sagunto, quien el año 216 a.C. entregó a Roma los rehenes que retenía Aníbal en la población; al respecto Polibio (III, 97, 2), aunque lo alaba como un prohombre, no deja de hacer una crítica que, según la redacción, abarca a todos los hispanos: "concibió el proyecto de entregar los rehenes, pensamiento digno de un ibero y de un bárbaro..." En el caso de Abelux la censura está más que justificada, este probable noble saguntino sobrevivió a la catástrofe del sitio de su ciudad, lo que ya induce a sospechar sobre la calidad de su coraje y dedicación a la causa de la independencia; a continuación anuda lazos de amistad con el general que había llevado a la ruina y a la muerte a Sagunto y a sus conciudadanos; y después, cuando el panorama se tiñe con las enseñas romanas, haciendo alarde de su diplomacia y de su probada ruindad, pacta la traición a Aníbal. Hay narrados en la literatura otros sucesos acerca del protagonismo de traidores nativos en el transcurso del desarrollo de la conquista, uno de los más relevante es el asesinato de Viriato, en el año 139 a.C., por tres allegados, Audax, Ditalcón y Minuro (App., Iber. LXXI. D.S. XXXIII, 21). Así pues, analizando los textos, comprobamos que la naturaleza de los iberos y celtas era como la de los romanos, proclive a la traición, desgraciadamente tiende a ser pauta regular en una guerra de exterminio como 
la que se desarrolló en Iberia. Hemos nombrado un saguntino y tres lusitanos, a continuación y sin ánimo alguno de abarcar las infamias propias de toda guerra, exponemos otros dos casos, uno acaecido en el año 211 a.C., que fue causa de la derrota romana frente a los cartagineses y de la muerte de Cneo y Publio Cornelio Escipión, los primeros generales romanos que pisaron suelo hispano. Se trata de la defección en masa de los mercenarios celtíberos contratados por Roma, a quienes Asdrúbal convenció, pagando una fuerte suma a los jefes de tropa y a los soldados, para que abandonaran el campamento legionario y se retiraran de la contienda (Liv. XXV, 33). El segundo suceso, datado en el año 206 a.C., se refiere a un miembro del estamento selecto de la ciudad de Castulo, a la que Livio (XXIV, 41) alude como "coiuncta societate Poenis, ut uxor inde Annibali esset", que traicionó a sus aliados cartagineses y a parte de sus propios conciudadanos. Se trata de Cerdubelo, quien en conversaciones secretas con agentes romanos, entrega a P.C. Escipión la ciudad y a los africanos que allí se encontraban al frente de Himilcón (Liv. XXVIII, 19). Verdaderamente los castulonenses fueron especialmente traidores a unos y otros conquistadores. En principio eran aliados de los cartagineses (puede que a la fuerza), pues incluso consta que Aníbal, según el texto de Livio, pudo casarse con una joven perteneciente a la nobleza oretana. Cuando P. y Cn. Escipión conquistaron, a costa de los africanos, parte de la Alta Andalucía, es decir las zonas importantes en cuanto a extracción de galena argentífera, pactan con ellos. Cuando mueren violentamente vuelven nuevamente su fidelidad a los cartagineses, y finalmente los traicionan (Liv. XXVIII, 19). Y unos y otros conquistadores aceptan la adhesión de este pueblo tan voluble pues habita un territorio idóneo para establecerse, y para acceder con facilidad a los pozos mineros, como el llamado Baebelo (Plin., $\mathrm{NH}$ XXXIII, 96), explotado primero por los oretanos, seguidamente por los cartagineses y por último por los romanos.

Sigamos con el tema central de este escrito, los caballos de Iberia, esos fuertes y nobles animales tan intrínsecamente unidos a los naturales, y que a través de los tiempos fueron montados por los romanos y explotada su cría, primero para la guerra, más adelante para ser exportados a la Urbe, en buena medida destinados a las competiciones circenses. Al respecto, y sintetizando, en determinados pasajes de la literatura clásica se lee como los conquistadores, ya definitivamente asentados en Hispania, disponen para sus fines bélicos de escuadro- nes de caballería nativos, como el aludido en el Bronce de Ascoli que documenta durante la guerra social, en el año 91 a.C., a la turma Saluitana, formada por jinetes hispanos procedentes del Alto Ebro, es decir de una tierra cuyos habitantes fueron muy reacios a perder la libertad. A los integrantes de la turma, por su valor, se les concedió la ciudadanía romana. Y comprobamos como romanos e itálicos que se asentaron en las provincias de Hispania, cuando llegaron a poseer tierras, a veces extensos latifundios, produjeron yeguadas para espectáculos, tal como es deducible de diversos documentos, entre los que seleccionamos las cartas que Símaco (cónsul en el año 399) envió a Eufrasio, un probable propietario de rebaños de caballos en Hispania, solicitándole de carreras destinados a juegos para preparar la pretura de su hijo (Symmach., Epist. LVIII-LX, LXII-LXIII) (Seeck, 1961). Acerca de la cría del ganado ha de indicarse, y permítasenos que nos apartemos de la realidad romana, que entre los terrenos del área de abastecimiento de los poblados peninsulares prerromanos tuvieron que existir dehesas cercadas, como después las hubo en las haciendas de los domini, donde se atendía al ganado caballar y más al selecto. No está claramente demostrado, pero por comparación etnológica puede suponerse. Aunque por otro lado es muy probable que el pasto, en parte, lo buscaran los mismos cuadrúpedos, a los que se les soltaba de día, si nos atenemos a un párrafo de Apiano (Iber. LIIILIV), cuando narra la insidiosa operación de L. Licinio Lúculo contra la ciudad vaccea de Intercantia (año 151 a.C.):"...por la noche un grave terror les poseyó (a los soldados romanos que sitiaban Intercantia): los caballos de los bárbaros que habían salido a buscar pasto antes de la llegada de Lúculo, al no encontrar la entrada de la ciudad, ya que Lúculo la rodeaba, se pusieron a dar vueltas a su alrededor con grandes relinchos y aterrorizaron a todos. Pues los que estaban dentro les contestaban..." La suelta de ganado por los terrenos aptos para que consiga el forraje, pensamos que en tierras comunales, fue una costumbre muy extendida entre los pueblos primitivos (Fig. 7), que ha perdurado hasta nuestros tiempos, por ejemplo aún en el Occidente asturiano pueden verse tropillas, dirigidas por el semental dominante, que recorren los montes, en terreno abierto, espacioso, bien aireado, con bosquecillos de pinos para guarecerse de la lluvia o del calor del mediodía, e incluso en el verano pernoctan a la intemperie. Este aspecto de la manutención no concierne a los de raza superior que debieron recibir un tratamiento más 


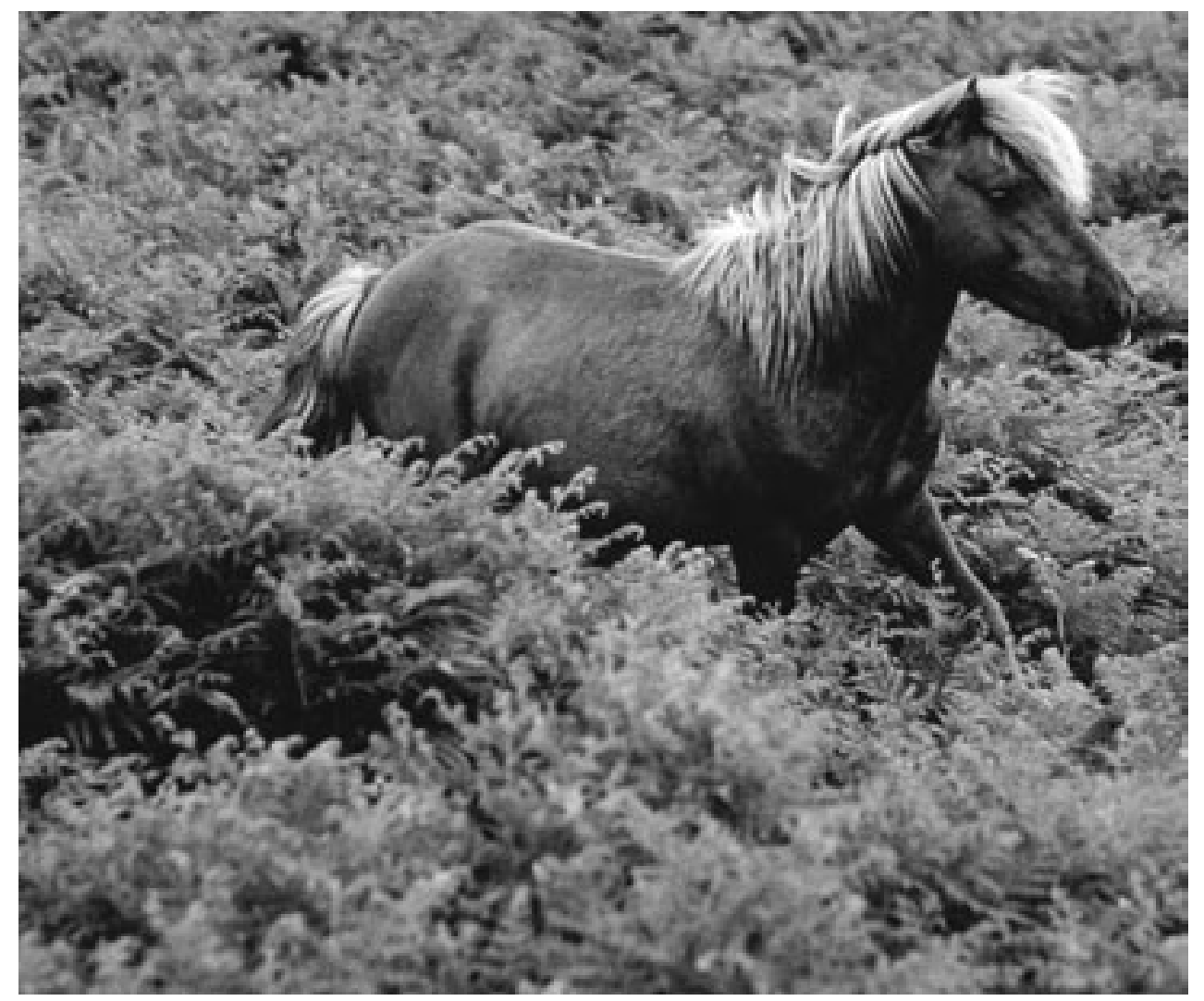

Figura 7: Caballo en su medio natural (Foto por Naturalis. A. Charlish y otros, 1981).

cuidadoso, una mayor atención, sería quizá el caso, en Intercantia, de los que se encontraban dentro de la ciudad por la noche, en abrigadas cuadras, bien protegidos de las alimañas, de los ladrones, de cualquier accidente o de cambios climáticos. Indudablemente al apuntar el sol los caballos para su desarrollo pleno eran sacados al aire libre, por lo menos en aquellos tiempos pedían libertad (y siempre), ¿en las dehesas limítrofes extramuros?, puede ser, desde luego debió existir una profunda especialización para conseguir los magníficos ejemplares equinos con pleno vigor y perfecta doma, de que hacían gala iberos y celtas, que llevaban a los jinetes a la caza, a la guerra.

\section{LA CONFIGURACIÓN SOCIAL Y SU ASOCIACIÓN CON EL CABALLO Y EL CARRO}

Las organizaciones tribales iberas y celtas, -éstas agrupadas en gentes y gentilitates, conocidas por la epigrafía latina-, están fuertemente ordenadas en clases sociales bien marcadas, tanto por la jerarquización de los asentamientos, como por la diferencia de superestructuras funerarias (en el área ibera), como por la variedad en cuanto a riqueza de los ajuares funerarios

En la cumbre hay un estamento sobresaliente, privilegiado, diversificado en nobleza ciudadana y señorío rural, todos ellos constituyentes de la aristocracia guerrera, cuyos componentes estarían ligados a menudo entre sí por lazos de parentesco. Este grupo monopoliza la política, los cargos directivos del ejército, la gestión y organización del mercado, el control de los excedentes, y con su poder establece con el pueblo lazos de clientela, fides, y lazos sagrados militares, devotio, con hombres destacados cercanos. En los textos grecolatinos personalidades públicas y privadas romanas, que por causas diversas entraron en contacto con los hispanos, hicieron uso de esta veterana y arraigada institución guerrera, llegando a reunir en torno a si a fuertes contingentes de peninsulares preclaros. Un caso, espigado entre los muchos conocidos, perfectamente atestiguado a estos efectos, fue el de Q.Sertorio (123-72 a.C.), Ilegado a Hispania huido de las famosas proscripciones de L.C. Sila. El político popular gozó de enorme predicamento entre las gentes del interior y de parte del litoral mediterráneo oriental. Y por diversos medios que ahora no vienen al caso, entre los que destaca 


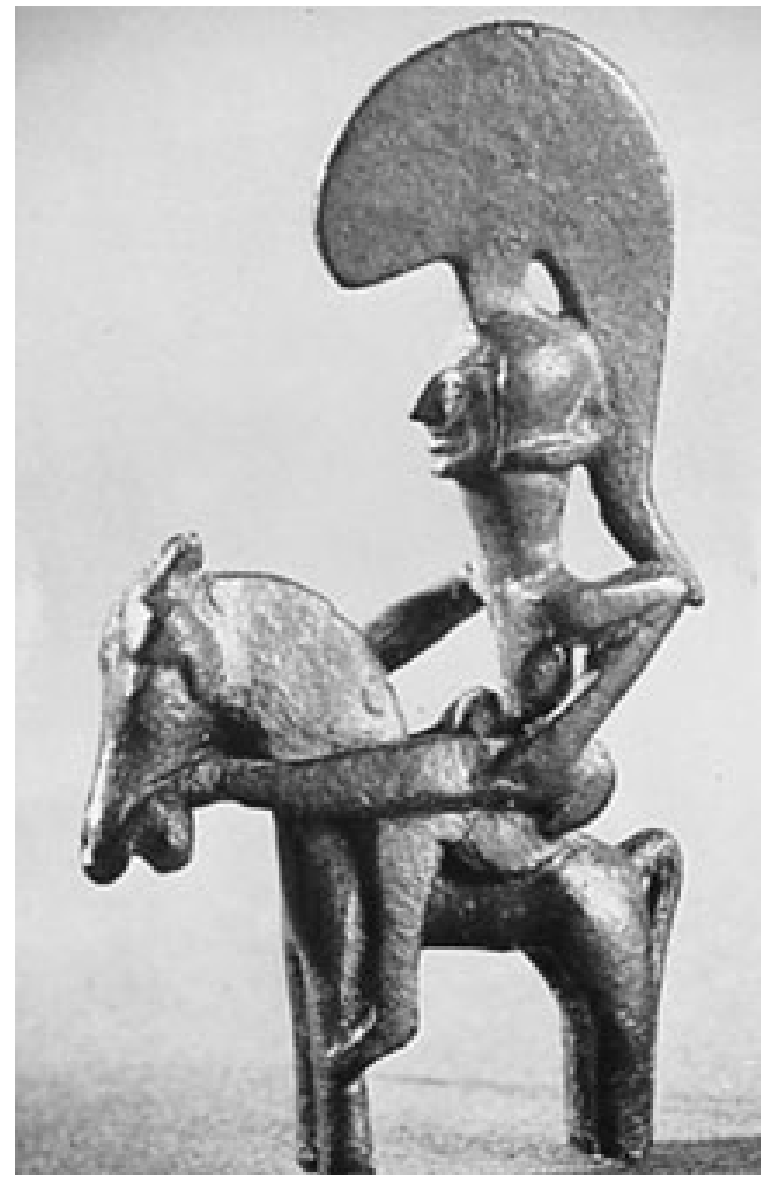

Figura 8: Exvoto representado un caballero. La Bastida, Mogente (Foto F. Quesada,1997, 185).

su fascinante personalidad, y el latente independentismo hispano, llegó a hacerse dueño de la gran mayoría de la Hispania Citerior. Y verosímilmente ligó a su causa a poblaciones enteras, utilizando el vínculo sagrado de la devotio. $\mathrm{Ha}$ de pensarse que varios de estos lugares fueran aquéllos que permanecieron fieles a su memoria, una vez resultó víctima de la conspiración de un cierto segmento de sus colaboradores cercanos. Dichas localidades ofrecieron a las tropas de Cn.Pompeyo Magno una resistencia desesperada, hasta morir la mayor parte de los habitantes: en el valle del Ebro Calagurris y Osca; en la costa mediterránea Valentia, y en Celtiberia Clunia, Termantia y Uxama.

Y los grupos preeminentes se hallan claramente atestiguados en la civilización ibera, como indicamos, a través de las sepulturas turriformes; de las de cámara-hipogeo o exentas, cubiertas o no por túmulos; de las señaladas con pilares estela; de las de empedrado tumular monumentales. Estos sepulcros suntuosos de los altos linajes como manifestaciones tanto de la posición elevada de los señores, como del culto a los muertos, a los mayores, eminentemente arraigado en todas las religiones antiguas, poseen un claro contenido propagandístico y contribuyen a la heroización, a la mitificación de los que allí yacen, cuya memoria realzan, y que una vez cerrado el sepulcro pueden llegar a adquirir el carácter de antepasados divinos o heroizados (sobre el tema J.M. Blázquez reflexiona infra). Tales tumbas igualmente enaltecen a los herederos, al hallarse éstos ligados por lazos de sangre a un ascendiente cercano a la divinidad. Efectivamente, redundarían en sentido positivo, encumbrando la situación política y la situación social privilegiada de los familiares de los difuntos.

Estos próceres que forman espontáneamente en el ejército en los cuadros dirigentes de la caballería, son reflejados en bronces como los que representan a un jinete desnudo con casco y armas (dos ejemplares registrados son de procedencia desconocida, hoy en el Museo de Cuenca y en el de Sant-Germain, respectivamente; en Espejo existen otros dos). Se les denomina tipo jinete de La Bastida, aludiendo al pequeño bronce de uno de los mayores poblados contestanos conocidos en la actualidad, La Bastida (Mogente, Valencia) (Fig. 8), que consiste en un jinete con un espléndido casco de alta cimera, empuñando en su mano derecha la falcata y en la izquierda la caetra. Han sido interpretados como vástagos de arranque, aunque también pudieran ser exvotos. El hecho de la desnudez del cuerpo les da, seguramente, un carácter sagrado. Aunque no obstante, en los santuarios ibéricos fueron depositados exvotos representado hombres desnudos con armas, y los mismos sólo tienen de sagrado el hecho de ser ofrecidos a la deidad titular del santuario en cuestión.Se fechan entre los años 475-450 a.C. En Numancia también han aparecido en el siglo II a.C. (Lorrio, Almagro-Gorbea, 2004-2005, 3760, Figs. 1-12).

Los dignatarios debieron emplear, como no el carro con tronco de caballos, que revalidaba su posición dominante, pero no era un arma de guerra (vid. infra). Y estos hombres preclaros, porque consideraban que era necesario para sus vivencias en el Más Allá, se hacen enterrar con ¿sus monturas?, o con un atributo de ellas, como los arreos (vid. supra); se hacen enterrar con su carro o carros, o tal vez la presencia del carro en el sepulcro tiene que ver con su heroización, y adquiere por tanto argumento simbólico, o sencillamente es un elemento más de un ajuar funerario suntuoso. Pero en realidad sobre el significado espiritual de los carros en las sepultu- 
ras, y en general sobre el significado exacto de los ajuares, que son el reflejo de ignoradas pero patentes creencias de ultratumba, desarrolladas materialmente, se sabe muy poco; veamos, es muy seductora la conjetura de que el carro suponía el símbolo del sol, en la eterna andadura de Oriente a Occidente, en el eterno ir y venir, que a la vez significaría el eterno transcurrir de la vida, del destino, de la perdurabilidad, mas no hay ninguna prueba concluyente que pueda sostener dicha presunción. Y podríamos seguir elaborando teorías sobre si el carro tuvo o no protagonismo en el espacio funerario en la tierra y en el del Allende, incluso basándonos en un esquema comparativo, pero siempre se quedarían en el rango de las suposiciones, porque no hay ni un solo escrito para apoyarnos, ni un solo dato en la plástica absolutamente fehaciente, absolutamente determinante, nada (vid.infra). He ahí, al respecto del hipotético tránsito al Mas Allá, en el que intervienen el caballo y el carro, la acción representada sobre un kalathos de Elche de la Sierra (Albacete) (Fig. 28), datado en el siglo II a.C. El desarrollo de la escena es el que sigue: un carruaje sencillo de varales y ruedas de reja, es tirado por dos caballos, dirigido por una persona, delante de la cual hay una gran rosa solar y debajo una roseta de cuatro pétalos, símbolos astrales. Detrás del carro, y parece que dialogando con otra persona, de la misma manera situada en la trasera del vehículo, hay una figura femenina alada de cuerpo acampanado que lleva de las bridas un caballo alado (Eiroa, 1986, 76-77), ¿una diosa conectada con el Más Allá, la Diosa Madre en su atribución de Señora del mundo subterráneo que ofrece el caballo alado a un difunto que ha de realizar el viaje al espacio donde moran los muertos o sus ánimas?. La traducción es muy arriesgada, pero la presencia de figuras aladas y del vehículo pueden hacer pensar, además de en alguna otra lectura que no viene al caso, en un acto relacionado con el paso a ultratumba, indudablemente sí es un episodio que se despega de la más absoluta cotidianeidad ¿entroncado con un mito? (vid. infra). Y aquí si que puede atestiguarse que el caballo alado tiene un sentido excepcional, no así los que tiran del carro, cuyo cometido es el sencillo de fuerza motriz. ¿O es el caballo alado una simple copia de la iconografía griega de Pegaso, conocida a través de las vasijas de importación? ¿O copia de los caballos alados etruscos? ¿O copia de los caballos alados próximo orientales? Si es una copia, por la datación lo sería mejor de la iconografía griega que de otras más antiguas. Bien, no sigamos por una senda tan inestable, en la que no es posible apoyarnos en argumentos sólidos, porque no los hay.

\section{LA RELIGIOSIDAD PENINSULAR PRERROMANA. BREVES APUNTES}

En la mentalidad de los miembros componentes de las tribus que vivieron en Iberia con anterioridad a la conquista romana, como en la mentalidad de la mayor parte de los hombres de todas las civilizaciones de todos los tiempos, hay una parcela que se halla firmemente unida a los sentimientos más íntimos de las personas y es la religión propia. Esa religión cuyos orígenes remotos apuntan hacia el totemismo, según $S$. Reinach una de las raíces universales de todos los dogmas.

La ideología hispana acerca de cielo y tierra no es conjeturable, la transmisión oral, la única forma de conocimiento de las tradiciones de pueblos prácticamente iletrados, evidentemente no llegó a nuestra época. En ningún caso fueron recogidos aquellos conceptos por la escritura, la cual se hallaba en un estadio primario de desarrollo. Tampoco fueron recogidos, a través de los años, cuando los indígenas hispanos se aculturan bajo Roma. Nadie, y nos referimos a los propios nativos de las clases distinguidas, ya en posesión del arte de escribir, nadie, repetimos, escribió sobre la religión vernácula de sus antepasados, a pesar de que aún pervivirá siglos y siglos en sus rasgos más esenciales, a veces incluso de forma soterrada y sobre todo en el ambiente rústico; nadie escribió sobre los mitos primigenios; nadie escribió sobre la propia historia ¿o es que no ha sido posible que llegaran los textos?. Tampoco escribieron extensamente, ni mucho menos, los hombres de letras grecolatinos, si acaso algún que otro comentario muy tangencial y difuso. $Y$ es inasequible a la investigación el captar el grandioso mundo de mitos, ritos, creencias, la mística poética del culto, a través de unos restos materiales y a través de la pobreza, opacidad y confusión de las fuentes literarias y epigráficas, desde luego no es posible oír una voz en el coro, como apuntaba Machado.

¿Cuál era la concepción de la creación del hombre, cuál la de la creación del mundo, cuál la del principio de los dioses? Nunca llegaremos a conocerlas, por lo menos hasta el momento no las conocemos, pero estamos seguros de no errar si afirmamos que la mentalidad religiosa ibera era sumamente complicada, y elaborada, y denotaba una sensibilidad acusada. Suponemos que en iguales términos podríamos escribir 
acerca de la mentalidad religiosa celta peninsular, pero de ella, en yacimientos, tenemos menos puntos de apoyo que para la ibera, aunque es mayor el aparato epigráfico.

La profunda vastedad de las creencias está bien atestiguada, para los iberos, en la pintura vascular, en realidad un soporte bien modesto; en algunos ejemplares tardíos que introducen al que los contempla en un ambiente ideológico abundante en matices y contenidos metafóricos míticos; en un ambiente a la vez tenebroso y oscuro; en un universo de monstruos y seres sobrehumanos enigmáticos, de incomprensible traducción, por lo que, volviendo a lo mismo, siempre nos movemos en el resbaladizo campo de las hipótesis. Es el caso de la escena figurativa sobre una tinaja de perfil troncocónico recuperada en el transcurso de las excavaciones de la Valentia republicana, en el estrato creado por las actividades bélicas, año 75 a.C., de Cn. Pompeyo Magno contra los partidarios de Q.Sertorio. Acerca del contenido deducimos que recrea un mito, cuya mayor aproximación a una incierta realidad sería armonizándolo con la procedencia del hombre. Otro contenido pictórico nebuloso, simbólico, difícil de interpretar como el anterior, es el de un vaso de Los Villares de Caudete de las Fuentes (Valencia) que podría datarse entre el siglo II a.C. y principios del siguiente. Sobre la superficie del recipiente seres de tamaño descomunal, fantásticos, híbridos, con las extremidades superiores finalizadas en garras, luchan de forma cruenta con hombres, dos de los cuales intentan, respectivamente, clavar una espada y un puñal en el cuerpo de los primeros; un varón más yace desarmado; la escena está rodeada de hojas, peces, tres carnívoros y una especie de centauro. E. Bonet e I. Izquierdo (2001, 185) propugnan que las acciones de este vaso y las del aparecido en la plaza de Cisneros, pudieran evocar leyendas que circulan por el Mediterráneo, y son trasmitidas a la Península Ibérica desde ambientes portuarios, en un momento en que Roma afianza progresivamente su poder. No compartimos esta opinión, las dos vasijas están datadas desde luego en una época muy tardía de la cultura ibérica, ésta ya en contacto directo con la aculturación de Roma; pero la religión constituye el último bastión ante los ataques de otras culturas, por ello las extrañas escenas reflejadas en la pintura vascular deben situarse en la más pura raíz de los mitos esenciales ibéricos; no hay por qué hacer depender gran parte de la cultura del espíritu y de la cultura material ibera de ámbitos extranjeros; no hay por qué presentar a los iberos, despojándolos de su natural protago- nismo, como simples imitadores y/o adaptadores de rasgos foráneos como los religiosos u otros, tan íntimos, tan esencialmente unidos a los sentimientos personales y colectivos de las estirpes.

\section{DIOSES}

Como en una gran parte de las religiones primitivas y contemporáneas los dioses no se personalizan o muy escasamente entre las tribus de Iberia. Solamente hay ciertas imágenes en el área ibérica, menos en el área indoeuropea, en escultura, relieve, orfebrería, diversos bronces, pintura vascular y numismática que, con un margen de duda, pudieran atribuirse a divinidades, siendo mayor el número de las femeninas que las de cualquier dios de carácter masculino.

Por lo que se refiere a los nombres divinos iberos, la carencia de fuentes nativas, la relativamente temprana aculturación romana, y el sincretismo religioso, la interpretatio indígena, han impedido saber denominaciones, en cambio sí se conocen los de algunas de deidades del área indoeuropea, menos aculturada, que para asimilarlos a la epigrafía latina en parte fueron modificados o admitieron la dicha interpretatio. $Y$ en diversos textos, en su narrativa, sin detenerse demasiado, y nunca con nombres, hay referencias muy generales a dioses hispanos, dioses celestes e infernales. Así durante la conquista de Astapa por Marcio (año 206 a.C.), narra Livio (XXVIII, 22; XXVIII, 23, 3. También App., Iber. XXXIII) como los astapenses, sabiendo que pronto estarían en manos de los sitiadores, eligen a cincuenta jóvenes (léase soldados) con el cometido de que si los defensores de la ciudad eran derrotados no debían dejar a nadie con vida "...a ellos les rogaban por los dioses del cielo y de los infiernos que acordándose de la libertad que aquel día debía morir o con una honrosa muerte o con una infame servidumbre, nada dejasen que pudiera servir de objeto de furor del enemigo..."; así es, dioses a los que se ruega o por los que se impone una acción, dioses que castigan o premian, dioses que refrendan y son testigos de los pactos entre contendientes, cual es el caso de la descripción por Apiano (Iber. L-LII) del sitio y toma de Cauca y del asesinato de los caucenses por L. Licinio Lúculo (año 151 a.C.), durante su insensata campaña bélica por la Meseta norte:"...les hace degollar a todos los caucenses sin distinción de edad. Éstos, invocando los pactos y los dioses testigos...". Igualmente en otro lugar, Apiano (Iber. LVIII-LX) alude a dioses, haciéndose eco de una nueva traición de otro general ro- 
mano, S. Galba, hacia los lusitanos (año 151-150 a.C.): "...una vez desarmados (los lusitanos), los cerca con una estacada, y enviando sobre ellos algunos soldados con espadas, los degüella a todos, mientras ellos le imploran invocando a los dioses y a la palabra dada..." Sobre estos atentados a la vida de miles y miles de personas es obligado hacerse la reflexión de que el faltar a la palabra empeñada, el asesinato, eran armas muy utilizadas por los generales romanos durante la guerra de conquista. Y si esto realizaban los mandos habrá que pensar que los subordinados no iban ni mucho menos a la zaga, suponemos que con la aquiescencia de aquéllos ("los desastres de la guerra", como el título de una de las series de la obra seriada de F. de Goya). Y finalmente, en el año 136 a.C., C. Emilio Lépido sitió la ciudad de Palantia, la más importante de los vacceos, de la que los romanos se retiraron por falta de víveres; los vacceos los atacaron pero, como informa Apiano (Iber. LXXX-LXXXIII. Y FHA, IV, 56), abandonaron el campo de batalla "obedeciendo a la indicación de algún dios". Parece ser, según A. Schulten $(1937,56)$, que hubo un eclipse de luna, por lo que les pareció prohibición de su, al parecer, dios luna, o bien un presagio enviado por otro de los dioses; el eclipse pudo significar estrictamente, sin más, un augurio adverso. $Y$ es muy probable que la luna fuera conceptuada como dios o diosa, teniendo presente el sentimiento religioso hacia el satélite de gran parte de las civilizaciones de la antigüedad o incluso de las primitivas actuales. Estrabón (III, 4, 16, véase frase literal más abajo) alude a la luna y a ceremonias, aunque a juicio de quienes escribimos, no aclara el panorama: las danzas rituales descritas por este autor no tuvieron necesariamente que estar destinadas a un dios luna, ni ser éste el "dios sin nombre". Lo más verosímil es que en el ambiente mágico creado por el plenilunio, más especial aún por ser difícil llegar a él en cielo raso o relativamente despejado en el ambiente climático del norte, se desarrollaran rituales en honor de ese "dios sin nombre" apuntado por el de Amasia, dios del cual, en realidad, desconocemos todo (vid. infra).

Siguiendo con los nombres de los dioses, bien es verdad que existía aversión por parte de los escritores grecolatinos, reflejo del sentir popular romano, a pronunciar, por su rudeza, vocablos hispanos. Sobre este argumento son ilustrativos algunos versos de Marcial, quien escribe en su epigrama IV, 55: “... nosotros hijos de los celtas y de los iberos, no nos avergonzamos de ensalzar en versos agradecidos los nombres algo rudos de nuestro país..." (se refiere a to- pónimos como Bílbilis, Platea, Tudela, Rixama, Gardua, Péteris, Rigas, Turgunto, Turesia, Tuetonisa, Burado, Vativer), y finaliza el epigrama con una pregunta a los lectores de la Urbe, que evidencia lo que piensan éstos de las lenguas no latinas: "¿Te causan risa, fino lector, estos nombres?". Y reitera en el epigrama XII, 18, nuevamente citando nombres hispanos de su tierra, Boterdo, otra vez Platea y Bílbilis: “...ve que nombres a cuál más ordinario éstos de mi tierra celtíbera...". Los escritores incluso son reacios a escribir denominaciones de dioses, como podría desprenderse de su ausencia en textos y posiblemente de unas frases de Estrabón (III, 4, 16) aplicadas a los hombres de las tribus interiores y septentrionales, que además tienen otras interpretaciones, algunas desarrolladas a continuación: “... Según ciertos autores los galaicos son ateos; mas no así los celtíberos y los otros pueblos que lindan con ellos por el norte, todos los cuales tienen una cierta divinidad innominada, a la que, en las noches de luna llena, las familias rinden culto danzando al amanecer, ante las puertas de sus casas". No es el sitio para escribir acerca del supuesto ateísmo de los galaicos, que no era tal, baste señalar que ya en los más remotos tiempos prehistóricos las bandas paleolíticas desarrollan un hondo universo de creencias con la lógica raíz naturalista. No es sostenible, bajo ningún concepto, una carencia de convicciones religiosas en pueblos primitivos, cuya dependencia del medio ambiente, su indefensión ante incluso el físico propio, aumentan la necesidad de crear un punto de apoyo protector, y aumentan la creencia en poderes maléficos y por ende en poderes benéficos que equilibren el mal que pudiera provenir de los primeros. Cuando a los clanes, hordas, tribus, les domina el pavor ante los fenómenos atmosféricos incontrolados, buscan la protección de poderes fuertes, los dioses, que atajen el desastre. Véase, como aún en nuestros días en alguna que otra comunidad, ante un peligro natural, como puede ser una prolongada sequía o al contrario, una inundación, los fieles cristianos exponen en procesión a esta o a aqueIla virgen, a este o a aquel santo, para lograr, del que proceda, la lluvia o la retirada de las aguas, o bien mediante rogativas sin la presencia en el exterior de la estatua sagrada. Respecto al dios que no puede ser nombrado (vid. supra), según la redacción de Estrabón, tiende a ser evidente imaginar que éste no supo o no quiso escribirlo, porque su pluma se resistía a los vocablos de las lenguas peninsulares. O también el motivo, presuponiendo la propaganda augustea, pudo estar en conexión directa con la realidad de la 
línea directora del libro III de su Geografía, sobre todo con respecto a los pueblos del interior y del norte, éstos recién sometidos por Augusto, es decir destacar el salvajismo de aquellas tribus, para justificar la conquista de Roma, que según la ideología política de la Metrópoli conllevaba una intensa labor civilizadora: si unos individuos no tienen capacidad para aplicar nombres a los seres supremos que rigen sus vidas, es que se hallan en un grado de desarrollo mínimo, luego está más que justificada la ingerencia de Roma en esas vidas tan salvajes, porque las van a incorporar, siempre mediante las armas y la explotación, al paraíso de la civilización romana. Otra posibilidad es pensar que era tan grandioso el ser divino, tal vez el Dios primordial, que su nombre no debía contaminarse en labios humanos, es decir que estaba prohibido por la mística montañesa, lo cual en el estadio de civilización de aquéllas entidades es excesivamente racional; o bien que, efectivamente, no tenía un nombre preciso, era el Dios primigenio por excelencia, el Dios creador, el Dios del que descendía todo ser viviente. Pero basándonos en los estudios etnológicos se comprueba que todos los númenes, que todos los dioses mayores y menores, tienen una personalidad bien definida, incluyendo el nombre. No creemos, por citar un pueblo relativamente conocido en la historia, por lo menos por el nombre, que los pelasgos, utilizados como modelo de barbarie por Heródoto (II, 52), no aplicaran de una manera u otra nombres a sus dioses, no creemos que se dirigieran a ellos con la denominación genérica de "dioses". Y es más, en el seno de las religiones se encuentran, incluso, las genealogías de los dioses o de los héroes o de los personajes semidivinos.

Volvamos al camino, continuando con los poderes de los dioses, con sus características, no para definirlos largamente, sino para ir discurriendo hacia la vertiente que atañe a este trabajo: rastrear un dios o diosa o ambos, muy concretamente de la cabaña equina, cuya misión era la de protección, en todos los aspectos, de la vida de tales animales.

Los hispanos, tanto unos como otros, iberos y celtas, teniendo presentes las características de sus culturas y, al respecto de los últimos, las características religiosas de la Céltica europea, que son a grandes rasgos las de la Céltica hispana, es muy difícil que no veneraran cada "nación" con un nombre (ignorado ahora), y con teología más o menos diferente, a la Diosa de la Naturaleza, de la Fecundidad, a la Diosa, tan vieja como el mundo. Esta Diosa que está estrechamente unida, en cuanto a su simbología, a todo lo que supone prosperidad, también a las fuentes, a las grutas, al subsuelo de donde surge la vegetación, la vida, "la divinidad única a quien venera el mundo entero bajo múltiples formas, variados ritos y los más diversos nombres" (Apul., Metamor. XI). Y en las afirmaciones precedentes prácticamente no se puede fallar porque el culto a la Gran Madre acompaña a la Humanidad incluso desde época paleolítica y alcanza mayor fuerza a partir de la sedentarización neolítica, la Gran Madre "de antes de los tiempos", según los bereberes; la expresión "anterior al tiempo" es bien elocuente del poder de la Diosa, en cuyo ámbito se sitúa la vida del hombre, de los animales, de las plantas, es decir de cualquier ser vivo. En el espacio indoeuropeo parece que se venera el concepto de la fertilidad, en todos los aspectos y para todos los seres vivientes, no a través de la Diosa singular sino de la Diosa plural, las "Matres", principalmente en triada, según F.J. Fernández Nieto $(1999,198)$ asimiladas a paredras de dioses del tipo de Cernunnos.

Las religiones peninsulares a la idea de la Diosa quizás asociaron, como en la mayor parte de las religiones politeístas de las sociedades pastoriles, ganaderas y agrícolas, el concepto de dios cósmico, el Creador, en cuanto al dominio divino de la procreación, los fenómenos meteorológicos y el proceso creativo en general, si bien tal dios debió quedar, en principio, oscurecido por la Diosa. Este dios desde luego sí fue adorado por las etnias indoeuropeas no solo por las hispanas sino por las de toda Europa, si admitimos que pudiera ser el gran dios pancéltico Lug, el "Luminoso" ¿el Sol?, el "Experto en Todo" y el que trasciende cualquier atribución de cualquier otro dios. De todas maneras, aún aceptando que Lug pudiera ser el Dios Padre, falta una base firme, a pesar de los múltiples indicios hallados en la epigrafía y en los textos célticos europeos. Efectivamente, volvemos a lo mismo, cuando trabajamos sobre los pueblos prerromanos siempre nos hallamos ante un panorama muy oscuro, así pues, y al respecto de la atribución de dios supremo a Lug, pudiera serlo, pero igualmente pudiera no serlo, pero eso sí, no nos movemos en un terreno resbaladizo si afirmamos que con seguridad fuera Lug, fuera Teutates, fuera Esus, fuera Taranis (Luc., Phars. I, 444) etc., existió un dios, o una triada creadora, suprema. Pero bien, no gira nuestro estudio sobre estos asuntos, aunque si nos interesa que quede bien subrayada la existencia de un Dios Supremo (o dioses) factotum, quien o quienes conjuntamente con la Diosa Madre, gobiernan el movimiento del mundo. Acerca de las religiones célticas, sus dioses 
y su incidencia en la Península lbérica, remitimos a un gran investigador, F. Marco, quien ha trabajado intensamente sobre el tema.

El dios o los dioses indoeuropeos verosímilmente tendrían su correspondencia en la religión de los iberos, pero de su dios o dioses dominantes de carácter masculino conocemos aún menos que acerca de los indoeuropeos. Dioses supremos con apariencia masculina en el ideario ibero ¿porque denotamos seguridad al afirmar su existencia? Porque aunque parezca que pecamos de una argumentación fácil, en los grandiosos panteones de la inmensa mayoría de las religiones pasadas existieron dioses mayores de carácter masculino y femenino, triadas, matrimonios, únicos. Al Dios celeste ibero, debe suponerse como a Lug, que sea un dios de carácter astral, y todo lo expuesto a continuación son elaboraciones mentales basadas en el estudio de religiones antiguas. Repetimos, al dios celeste ibero en su condición astral que todo lo abarca, aire y "viento que sopla donde quiere", se le pudo considerar como dios de los fenómenos atmosféricos que garantizaba el orden universal y el ritmo de la naturaleza. La Diosa siguió ocupando el primer puesto en el drama estacional en que ambos consortes, masculino y femenino, jugaban sus respectivos papeles en el mantenimiento de la continuidad de la naturaleza, de la fertilidad de la tierra y en el proceso generativo en todos los aspectos. Mientras, en una penumbra cósmica, se mantenía la figura del Dios Celeste dominando todas las cosas desde su lejanía (Bleeker, Widengren, 1973, 39. Lincoln, 1991). Es probable que así fuera, es la argumentación lógica mental propia, aconsejada por años y años de estudios sobre religiones primitivas. Este dios, que porque las sociedades de lberia se distinguen por su combatividad, hubo de tener un carácter guerrero, además del primordial Dios supremo.

Una pintura ibera muy escueta, pero repleta de símbolos vegetales y animales, la carga de la fecundidad, de la Diosa y del Dios, si es que una de ellas representa un varón, pudieran ser las dos caras, bajo sendas asas falsas, de un kalathos de La Alcudia (Aranegui, 1998, 184. Catalogación, 302,303). Entre otros autores J. González Alcalde (1997, 337-338), atribuye las dos caras, a las que denomina máscaras, al sexo femenino, es decir a la Diosa.

$Y$ los hispanos adoraron, asimismo, a otros muchos dioses, númenes, genios, héroes, tantos como carencias sufrían. $Y$ es interesante resaltar, a pesar de que es tardío (fines del siglo II, principios del siglo III) y de limitado valor his- tórico, el testimonio de Tertuliano (Apologeticum, XXIV, 7) quien escribe que cada región tenía un dios.

\section{LA DIOSA Y SU PAREDRO EN EL PANTEÓN IBÉRICO. SU PROBABLE ATRIBUCIÓN COMO DIVINIDADES PROTECTORAS DE LOS ANIMALES (CABALLOS), O DIOSES TUTELARES ESPECÍFICOS}

El culto a la Diosa Madre mediterránea, a las "Matres" celtas, suponía una religión comunal y naturalista que giraba en torno a la idea de la salud y del bienestar, y que tenía como fin último la conservación de la vida en todos los aspectos, hecho racional en un tiempo en el que la fuerza de la Naturaleza era muy superior a cualquier intento de modificación antrópica de su curso. Siempre bajo los cultos a la Madre primigenia subyace la idea de la fecundidad en el sentido más amplio. En este rumbo, el origen, desarrollo $y$ fin de la comunidad de fieles desde un punto de vista histórico-social, se confunde con el origen desarrollo y características de la divinidad que adoran, es decir, de la Diosa o diosas supremas, cuyo origen es la Gran Madre primordial.

Con un margen de duda amplio, figuraciones de la Diosa en los territorios iberos son las expresadas en líneas más abajo, aunque uno de los aspectos ideológicos propios de las religiones hispanas, ya se apuntó en otro lugar, es el relativo a que la mayor parte de las divinidades trascienden cualquier testimonio físico, los dioses no se complacen en contenerse en aspecto humano. La Diosa ibera iconográficamente pudo llegar a adoptar la efigie de Tanit, más con el significado propio de la deidad suprema indígena, que al fin $y$ al cabo viene a ser el mismo que el de todas y cada una de las diosas nutricias mediterráneas. Son estas las anunciadas posibles imágenes de la Diosa: las figuras, aladas o no, de la pintura vascular del estilo Elche-Archena, las Damas de Elche (Alicante), de Cabezo Lucero (Guardamar de Segura, Alicante), de Baza (Granada), que sostiene en la mano izquierda una pequeña paloma azul (uno de los símbolos tradicionales de Tanit), la entronizada de Elche, sujetando en la mano derecha una rama de adormidera, la de Cabecico del Tesoro (Verdolay, Murcia) y la de Llano de la Consolación (Montealegre del Castillo, Albacete). Asimismo la escena del pinax de terracota de La Serreta (Alcoy, Alicante) puede recrear un acto de culto, litúrgico, con el protagonismo de la Diosa: en el centro, una mujer vestida y parece que sentada,- la Diosa-, amamanta 
a dos niños; a su izquierda, junto al trono, una paloma, -pudo existir otra en el lado opuesto-, de pie dos participantes en el ritual, un niño y un adulto, tocan el aulós; a su derecha una mujer, en pie, sujeta por el pecho a un niño crecido ¿su hijo?, acaso los oferentes (Fig. 9); los niños, prácticamente los únicos representados en la plástica ibera, la paloma ¿signo de Tanit? ¿ofrenda?, la música, evidencian, como indicamos, unas actividades religiosas en torno a la Diosa de la fecundidad ibera, si es que lo es la figura central.

Giremos nuevamente hacia el universo de los caballos. En términos generales no debe sorprender en una tierra prolífica en équidos, primero en estado salvaje y después domesticados, la aparición entre los mismos de una divinidad sobresaliente bienhechora, sean el Dios o la Diosa supremos o ambos, -serían venerados bajo los más diversos aspectos y atribuciones, como el tratado, sin menoscabo de su poder omnipotente-, sea una divinidad menor específica, de carácter masculino o femenino o bisexual, o sean dos las divinidades, una de cada carácter. El temor de los hispanos de que cualquier mal afectara a sus bestias, creó la necesidad de un ser supremo protector de ellas, y generó, con toda probabilidad rápidamente, atribuciones benéficas de los dioses de su panteón hacia su ganado caballar. Ese dios salutífero para los caballos era imprescindible, porque éstos, continuamos recalcando, eran parte integrante, esencial, de

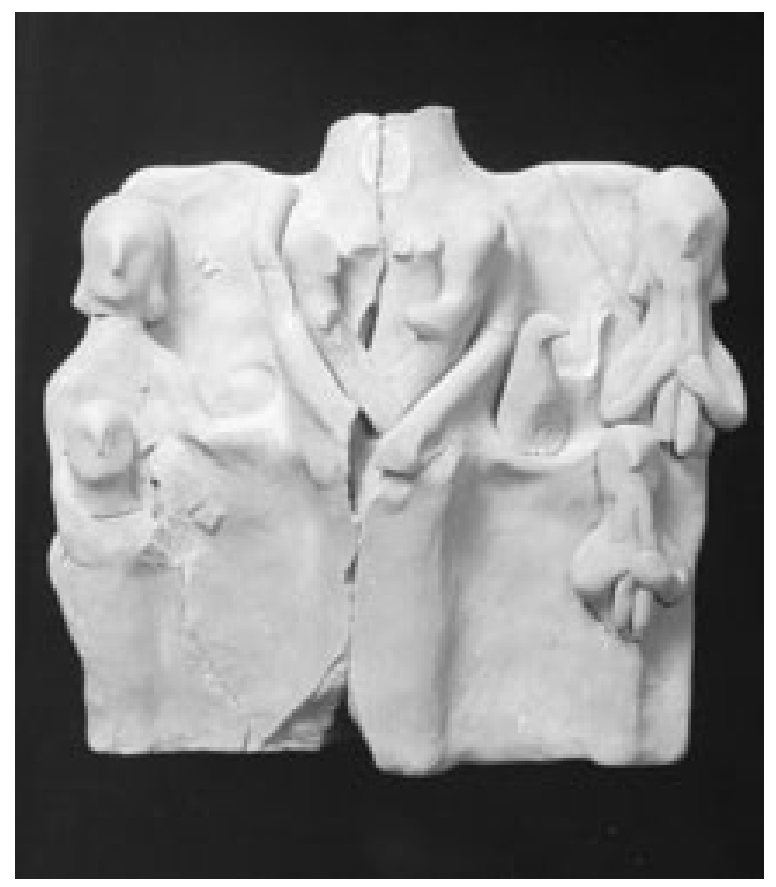

Figura 9: La Diosa Madre. Terracota del santuario de La Serreta, Alcoy (Foto Ministerio de Cultura).

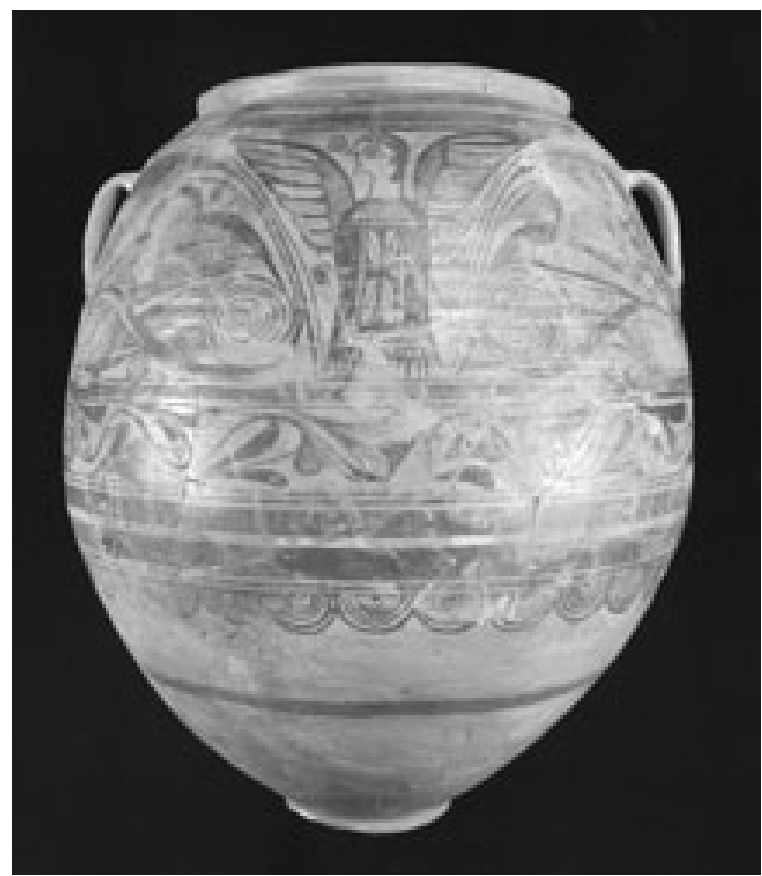

Figura 10: La Diosa Madre sobre una vasija. La Alcudia, Elche (Foto Catálogo El Mundo Ibérico una nueva imagen en los albores del año 2000).

los ejércitos tribales, eran los animales propios, emblemáticos, de la poderosa clase aristócrata guerrera, y constituían para los menos afortunados uno de los medios indispensables para promocionarse; y en el primer supuesto no dejaron de ser estimados por sus amos por poseer un número considerable, pues algunos, cómo no, serían dueños de nutridas yeguadas (Quesada, 1997, 185-195).

En las regiones célticas peninsulares hay testimonios epigráficos [(Lara de los Infantes (Burgos), Sigüenza (Guadalajara), Monte Bernorio (Palencia)], y plásticos [Sigüenza, Marquínes, Albaina (Álava)] (Marco, 1994, 337), de la existencia de una diosa ¿patrona de los caballos?, es Epona, cuyas evidencias igualmente se hallan en la mayor parte de Europa. La diosa, además de su relación con los caballos, tiene una fuerte conexión con la fecundidad y con el Más Allá, asociación comúnmente constatada en la mayor parte de las atribuciones de los dioses mayores del panteón de las religiones más arcaicas; y en casos a Epona se la aúna con las "Matres". Unas divinidades, adoradas por lo menos entre los indígenas septentrionales, y tal vez en íntima correspondencia con los caballos, son los Dei Equeunu. Los halló F. Marco en una inscripción sobre un ara depositada en el interior de la ermita de San Lorenzo (La Vid, Pola de Gordón, León) (Marco, 1998, 481-490) (vid. infra). Epona y/o los 
Dei Equeunu indoeuropeos pudieran ser aspectos particulares de los dioses supremos, por lo menos el simbolismo de Epona es tan complejo que rebasa la sola atribución de Señora de los Caballos.

En el área ibérica no hay dioses que se correspondan con los indicados para el área indoeuropea, pero reiteramos, epigráficamente prácticamente no hay testimonio de teónimos. Mas véase, allí donde falta la epigrafía es compensada (en cierto modo) por la plástica, y así la deidad suprema masculina ibera bajo la advocación concreta de favorecedor de los caballos o un ser divino menor, es susceptible de relacionarse con la figura de un varón, (a veces aparece asexuada), como eje central, y dos o cuatro caballos afrontados, iconografía que se halla en todo el Mediterráneo, tratamos de él más adelante.

\section{LA DIOSA COMO SEÑORA DE LOS ANIMALES EN LA PLÁSTICA IBERA}

\section{Pintura vascular}

En la pintura es visible el principio femenino en íntima unión con la divinidad primigenia, la Gran Diosa neolítica (Kuhahn, 1962, 80). Concretamente las vasijas encuadradas dentro del estilo simbólico (Elche-Archena), fechadas desde el último cuarto del siglo III hasta la mitad del siglo I a.C. (Menéndez, 1988, 413), y que se distribuyen especialmente en Contestania meridional y parte de Bastetania, han proporcionado, repetidamente, deidades con alas o sin ellas, algunas (no aladas) en cierto movimiento, con extraordinaria energía vital, y vestidos de calidad. Se figuran en solitario (Fig. 10), con animales diversos, ciertas entre caballos, y con un nutrido repertorio de signos, acaso la mayoría símbolos asimilados también a la diosa cartaginesa Tanit; otros pudieran parecer sencillos elementos decorativos, mas ha de tenerse bien presente que en la cerámica de Elche-Archena ningún rasgo gráfico debió ser superfluo.

Una de las representaciones más sugerente de la Señora de los Caballos es la efigie de cuerpo acampanado, vestida con túnica de manga corta, colocada de frente, alas extendidas y dominando, estática, sujetando de las bridas, a dos caballos rampantes, parece que provistos de alas (Fig. 11). Se representó sobre una tinaja de La Alcudia (Elche) (Pericot, 1979, 87, Fig. 109. Blázquez, 1983, 181-184, Fig. 102. Maestro, 1989. Ramos, 1991). ¿Se trata de una diosa menor valedora concreta de tales cuadrúpedos?, reiteramos que más verosímilmente es la imagen de una atribución determinada de la Diosa Madre: como Señora de los Caballos. Ahora bien, hemos de hacer una precisión, por la simplicidad del dibujo no hay definición de sexo y no hay adornos de joyas, éstas suelen hallarse habitualmente en las figuraciones de diosas o personajes relevantes femeninos como símbolo de dignidad y poder. Así pues, de la misma manera que aludimos a que es la personificación de una diosa pudiera serlo de un dios, en igual línea se define C. Aranegui (1998, 250), mas de lo que no puede dudarse es de que se trata de una divinidad y ésta asociada a los équidos. Exacta divinidad, alada o no, en algunos casos claramente de carácter femenino, sin caballos, es representada en otras vasijas de La Alcudia, rodeada de aves, conejos, peces, motivos vegetales como hojas de hiedra, flores, rosetas, algunas de estas con alas (símbolo astral de perduración hasta nuestros día, ahora sin un contenido claro, aunque aún en aldeas del norte es colocado (incisión, relieve, talla) con una cierta función instintiva protectora, eco de las creencias de los ancestros originarios, en las puertas de lugares como los hórreos, las paneras, en los aleros de los tejados de las casas, en los arcones donde se guarda parte de la comida) (Pericot, 1979, 73, Fig. 94; 91, Fig. 115; 114, Fig. 150; 118, Fig. 154. Blázquez, 1983, Lám. 111). Toda esta simbología, ya lo indicamos, constituye también parte del cortejo de Tanit.

En cuanto a la precisa imagen, en cuanto a la expresión pictórica de la Diosa, subrayamos que hay dos aspectos: uno el sentido religioso natural aportado por cada religión, en este caso por la de los iberos, que estaría reflejando acaso a la propia Diosa Madre de la Fecundidad, para nuestro estudio guardadora de los caballos. Otro

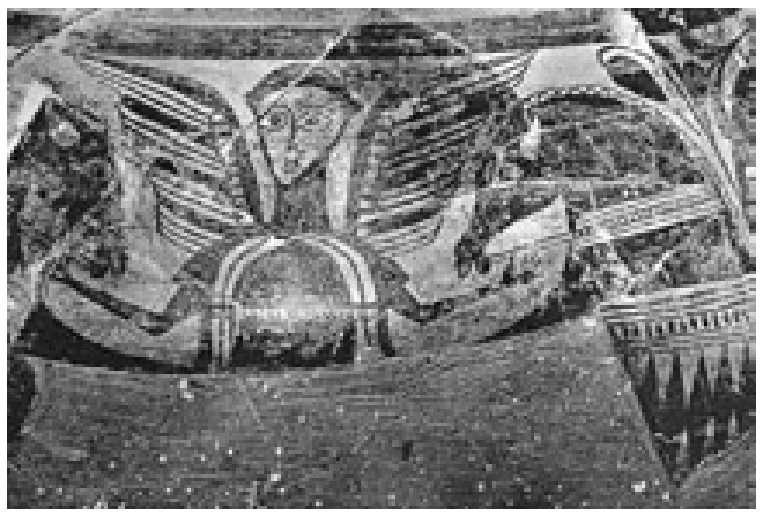

Figura 11: La Diosa Madre de los Animales, como protectora de los caballos, representada en una tinaja. La Alcudia, Elche. 
es el iconográfico material, que pudo ser creación propia,- no creemos-, o tomado, y de hecho debió ser así, de la iconografía de Tanit, en su atribución de Diosa de la Fecundidad. Pero enfatizamos en este segundo aspecto, exclusivamente el iconográfico material (Marín Ceballos, 1987, passim. González Alcalde, 1997, 334-339). Virgilio (Aen. CCCCXLII) pone en relación a Tanit (dejamos de lado la controversia Astarté/Tanit ¿una o dos diosas?) con una cabeza de caballo; y en la imaginería cartaginesa Tanit como Diosa de la Fecundidad se halla, entre otras especies, vinculada a los caballos. La específica iconografía material de la Diosa Madre Tanit, como Señora de los Caballos, adaptada a la diosa ibera de similares atribuciones, es muy aceptable pues, teniendo presente, igualmente, el profundo enraizamiento de las tradiciones cartaginesas entre las tribus mediterráneas hispanas del este y sudeste y el culto a Tanit en Ibiza, isla netamente púnica en cuanto a su poblamiento foráneo.

Pero la iconografía que se contempla en la pintura de Elche-Archena, aceptando que en última instancia procede de la de Tanit, que puede aparecer con alas, como las diosas Anat de Ugarit, Isthar de Mesopotamia, Isis de Egipto, quizás no fue autóctona de Cartago y arribó a la ciudad africana por vías sinuosas, con múltiples ramificaciones y bifurcaciones. Son caminos difíciles de rastrear, caminos con innumerables obstáculos por la carencia, no absoluta, de apoyo. Y no obstante, diversos colegas han establecido ciertos puentes desde la Península Ibérica hacia otras civilizaciones occidentales y próximo orientales o viceversa; entre la numerosa bibliografía existente remitimos a los trabajos de M.E. Aubet (1976), M.C. Marín Ceballos (1987), M. Menéndez (1988), J. González Alcalde (1997). Véase un desarrollo pictórico que en cuanto a iconografía y estilo recuerda a las figuras de carácter femenino de la pintura vascular de Elche-Archena: se encuentra en un ánfora de Beocia, concretamente de Tebas, datada alrededor del año 680 a.C. En ella es representada una diosa no alada (aceptando que las figuras de Elche-Archena son diosas). Es una efigie frontal con unos brazos largos ondulantes que parecen acoger a dos lobos con las fauces abiertas, a ¿la cabeza de un caballo?, a aves y a peces que la circundan; signos astrales de difícil interpretación se hallan aquí y allá, sin un orden claro (Fig. 12). Sería, por tanto, la expresión plástica de una diosa de la fecundidad, de una diosa de la vida, pero ¿cuál?, ¿Artemis, Afrodita, Deméter, Perséfone?, todas ellas enlazadas de alguna forma con el primigenio mito oriental de la Gran Madre, con los más remotos

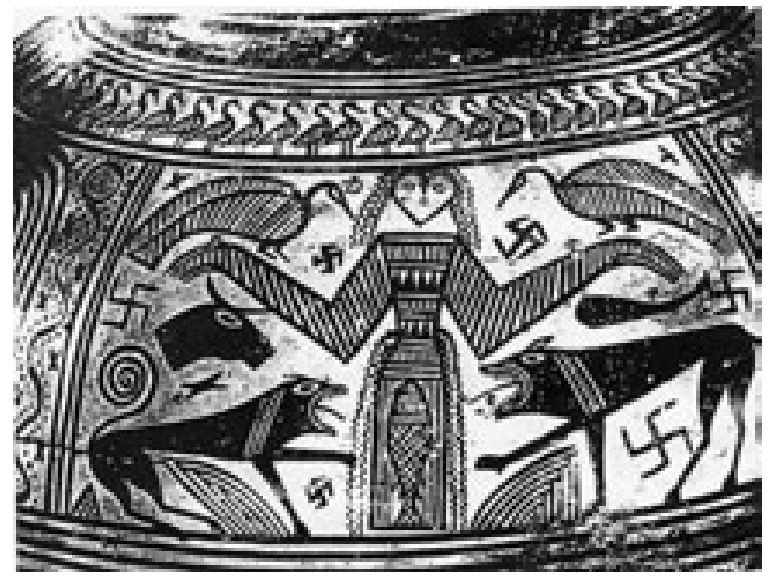

Figura 12: Ánfora con representación de la Diosa Madre. Tebas, ca. 680 a.C.

ciclos de la Madre Naturaleza: nacimiento, vida, muerte, resurrección, subyacentes en la raíz de las religiones, y su entronque en el ideario humano con los ritmos de vida, muerte, esperanza de inmortalidad. Sobre su posible influencia en la plástica de Elche-Archena no nos decantamos en este estudio, salvo plantear la diferencia cronológica existente entre unos y otros productos, vaso de Tebas, 680 a.C., estilo Elche-Archena, último cuarto del siglo III hasta la mitad del siglo I a.C. Pero sí consideramos interesante resaltar aquí, porque vienen al caso respecto a la similitud entre las pinturas de Tebas y Elche, las opiniones de M.E. Aubet (1976, 64, 78-79) y M.C. Marín Ceballos $(1987,52)$, y las transmitimos recogidas por J. González Alcalde (1997, 333): "Durante el siglo IV a.C. la influencia griega en todo el Mediterráneo fue enorme. Deméter y Coré llegaron a Cartago desde Sicilia donde, a su vez, hubo un culto preexistente a una divinidad de características semejantes. Habría una influencia de estas diosas en las representaciones de Tanit como la había de Isis, pero no un sincretismo entre Tanit, Isis y Deméter y Coré, sino la adopción de determinadas formas de los sistemas de representación egipcio y griego". En un vaso ático del siglo VI a.C. Atenea aparece modelando un caballo (Yalouris, 1950), lo cual podría estar significando que es hacedora de estos animales. Y quizá la Diosa Virgen, aún siéndolo, fue considerada, en alguna época remota, responsable de la vida de sus atenienses y de los animales y vegetales de los mismos, y desde luego su radio de acción debió estar siempre limitado al Ática. Pero parece ser un aspecto aislado de la hija de Zeus, y no ha lugar a integrar a la dicha en la serie de diosas plenamente relacionadas con la fecundidad y protectoras de los caballos. 


\section{Bronces diversos}

Una imagen femenina representa a la diosa fenicia Astarté, la Gran Dama del Cielo, aseguramos que lo es por sus atributos. Fue hallada en Castulo, en tres bronces. Está creada con el peinado de Hathor y orejas de vaca. Cubre la cabeza un lirio egipcio. Viste túnica de manga corta, ajustada al cuerpo, con la falda adornada con cenefas verticales de finas aspas. Sostiene sobre el pecho una flor. Un fragmento de bronce, asociado a Astarté, era parte del cuerpo de un caballo (Fig. 13). La cronología debe situarse en torno al siglo VI a.C. Se trata de piezas importadas fenicias, que formaban parte de uno o dos trípodes con sus correspondientes calderos adornados con figuras de Astarté y caballos. Ahora bien, tomó por parte de los castulonenses que adquirieron tales objetos rituales, el carácter de su propia Diosa fundamental, en su acepción de Señora de los Animales como Señora de los Caballos, cuya designación no conocemos. Y recalcamos categóricamente el aserto anterior con respecto a que en Castulo Astarté encarna a la Diosa autóctona, porque es impensable que los castulonenses, igual que cualquier otros hispanos, adoraran a una

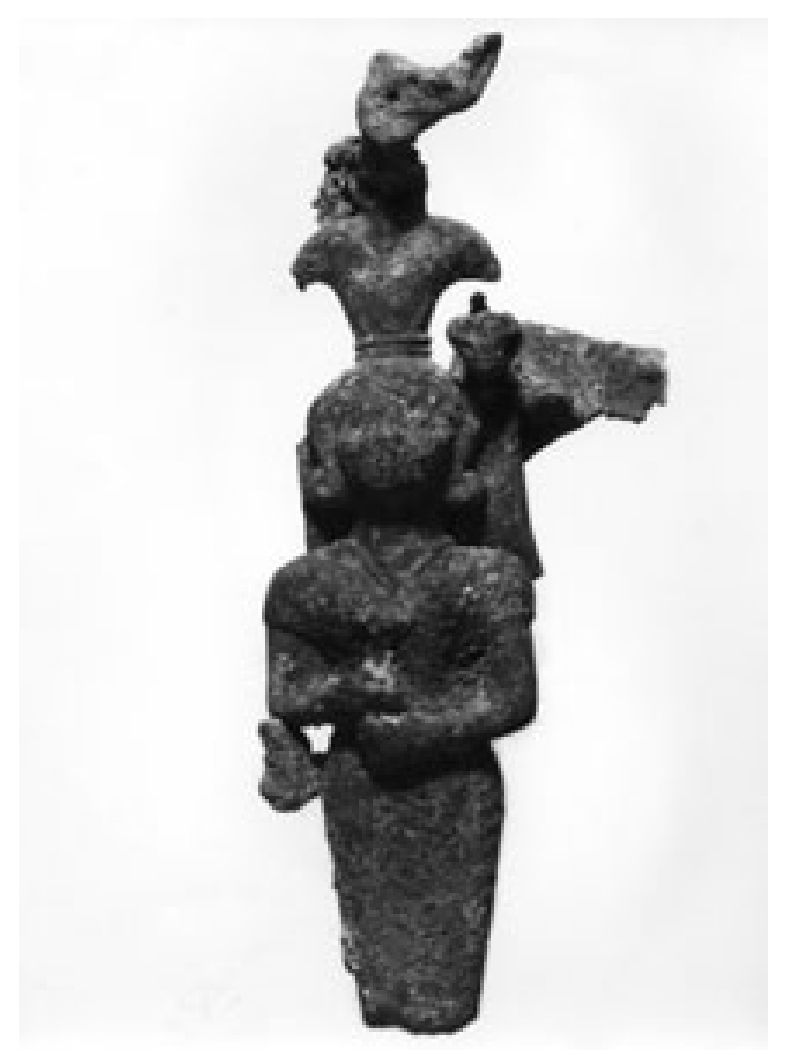

Figura 13: La Diosa Madre de los Animales, como protectora de los caballos, con estética e iconografía oriental. Castulo. diosa foránea como Astarté, por mucho fervor que tuvieran por ella sus devotos fenicios que la crearon, y con los que los grupos humanos meridionales hispanos llegaron a tener un estrecho contacto. La vinculación de la diosa fenicia Astarté con los équidos juzgamos es bastante evidente, igual que su conexión con las serpientes, con las aves, con todos los animales en fin, en su aspecto de Diosa de la Fecundidad o Señora de los Animales, que es aproximadamente equivalente. Véase como un texto de Ugarit menciona los caballos de Astarté (TU-00-1.86, $6)$, y a caballo, entronizada, es representada la diosa fenicia en una terracota de Chipre, que estudió V. Karageorghis (1997, 195-206, passim). Por tales razones y por otras varias, recogidas en los textos, los pueblos indígenas del litoral mediterráneo o totalizando, todos aquellos que tuvieron tratos comerciales con los fenicios y después con los cartagineses, no es insólito que asimilaran como imágenes físicas de la Diosa Madre hispana, que al fin y al cabo con distintos nombres viene a ser la Diosa venerada por todos los hombres, a las esculturillas de las diosas honradas por aquellos colonos y/o mercaderes, Astarté, Tanit. Aquellas figurillas que se hallaban en gran parte en poder de las clases privilegiadas hispanas entre las que podían encontrarse hombres sagrados, y que fueron conseguidas mediante dones o mediante tratos comerciales, en principio con los fenicios, más tarde con los cartagineses.

La manifestación tangible de una divinidad protectora de los équidos igualmente enriquece arneses de caballos, lo que viene en cierto sentido a probar su identificación con el bienestar de los mismos, aunque no estén representados físicamente. Es el caso de la efigie de una diosa en algunos bocados, cuyo significado pudiera ser profiláctico, como el comprado en un rastro de Sevilla, de claro origen oriental, que representa a Astarté en un busto femenino vestido, collar inciso de flores de loto sobre el pecho y los brazos desnudos extendidos; a ambos lados dos prótomos de pato unidos por el centro (Fig. 14); a pesar de hallarse fuera de contexto podría fecharse en torno al siglo VI a.C.; indicamos lo especificado para la Astarté de Castulo, bajo la figurilla importada de la Diosa fenicia se halla la Diosa indígena. También el de la cama de un bocado del yacimiento de Cancho Roano, del primer cuarto del siglo IV a.C. o antes, pues J. Maluquer (1981, 276-277, 331-333) sitúa el final del yacimiento alrededor del año 370 a.C. En él se representan dos prótomos de caballo con las cabezas hacia el exterior y un personaje bifronte en el centro 


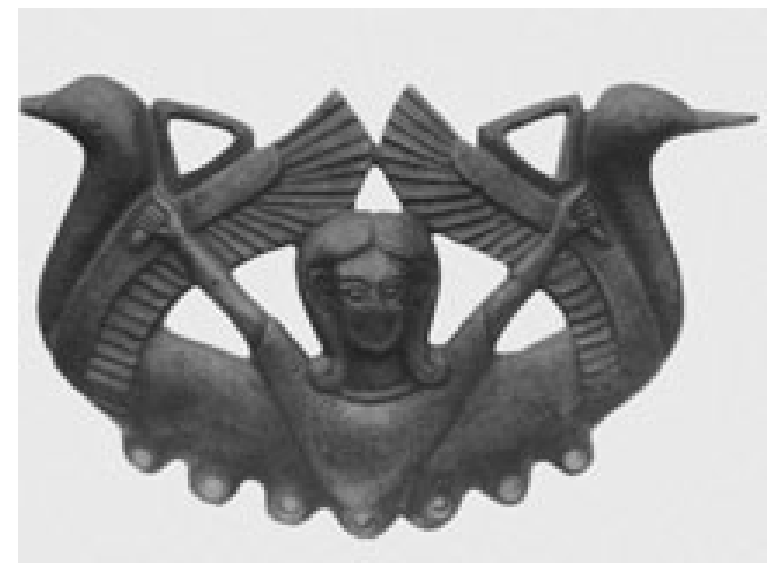

Figura 14: Bocado de caballo en el que se representa a la Diosa Madre. Sevilla.

(Fig. 15); este bocado coincide con el de Sevilla en cuanto a poder protector para los caballos, y ratificaría la existencia de una deidad afín a tal cabaña en poblaciones nativas, en este caso las de los túrdulos. Sus descubridores no aseguran el género de la figura antropomorfa (Maluquer, Aubet, 1980, 325, Fig. 37), nos atenemos a esta duda razonable, por una parte considerando que el objeto está muy deteriorado, y por otra que la figura tiende a ser asexuada. De una forma u otra, sea del sexo que fuere, de lo que no cabe duda es de que se trata de un ente divino entre tales cuadrúpedos, el mismo atestiguado en los relieves sobre piedra en los que se figura una efigie, bifronte o no, entre caballos (vid. infra).

Del mismo modo, la Diosa de los Animales, de los Caballos, se ha hallado en joyas, siempre

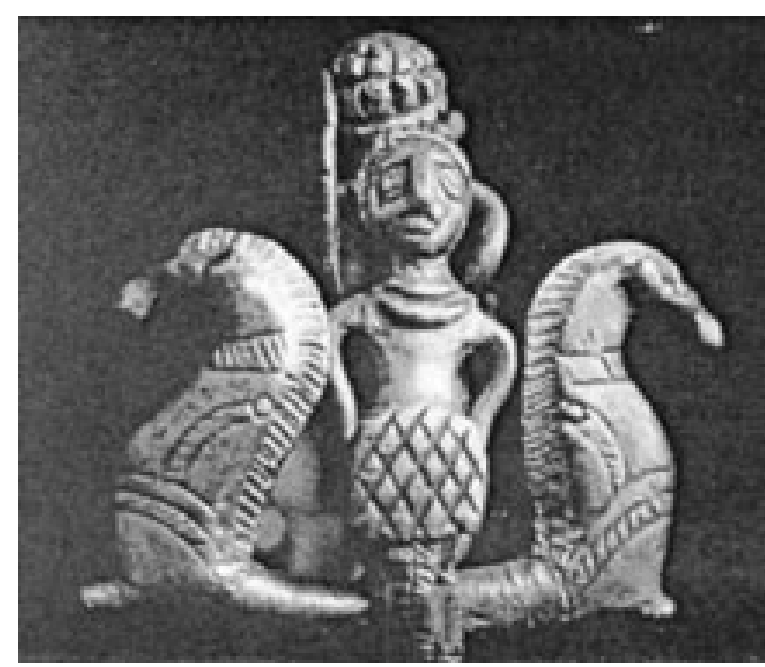

Figura 16: Posible fíbula con representación de la Diosa Madre en su relación con los caballos. Museo Provincial de Jaén.

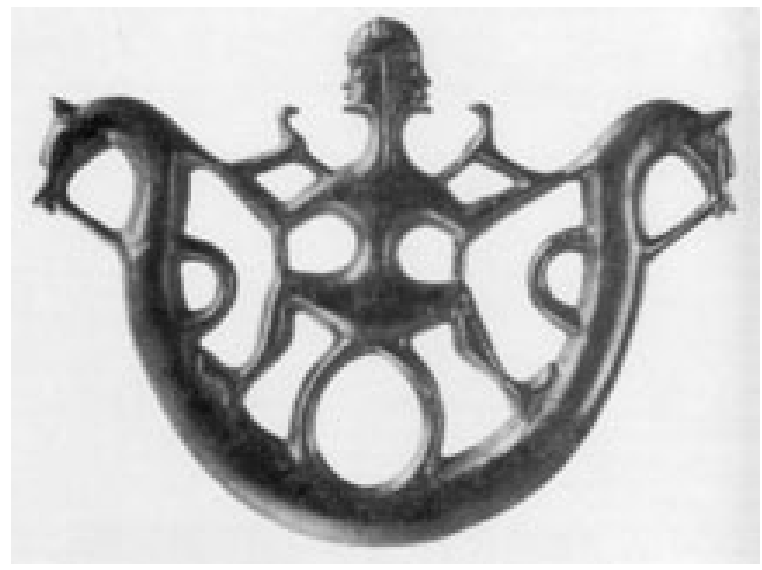

Figura 15: Bocado de caballo con dios bifronte. Cancho Roano (Foto Almagro-Gorbea, 2005, 70).

éstas símbolo de poder. Una es la conservada en el Museo Provincial de Jaén, que según uno de nosotros (Blázquez, 1997, 89, Tav. XV, 2) debe formar parte de una fíbula, datada entre los siglos III-II a.C. Representa una dama entre prótomos de caballo vestida con traje ceñido y las manos apoyadas en las caderas (Fig. 16). La figura no muestra con claridad su carácter femenino, pero los collares parecen confirmar tal género.

La Diosa vuelve a estar presente en otras fíbulas, como las halladas en el asentamiento de La Muela de Taracena (Guadalajara), en tierras de Celtiberia; Cañete de las Torres (Córdoba); Los Villares de Caudete de las Fuentes. En todas ellas en el arco se representa una escena de caza (jinete, perros, jabalí) y un ser femenino entre dos prótomos de caballo (Marín Ceballos, Padilla, 1997, 469).

\section{EL DIOS EN LA PLÁSTICA}

\section{El Dios sobre lastras /bloques de piedra}

Los relieves catalogados son doce. La imagen central y eje de la escena es antropomorfa, puede ser un varón, de pie o sentado sobre una pequeña y sencilla silla de tijera, y a ambos lados sendos caballos, excepto en un relieve en el que hay cuatro animales (Llano de la Consolación). Todos levantan las patas delanteras, salvo los de La Encarnación (Caravaca, Murcia), cuyas extremidades se fijaron en actitud de iniciar el trote, y los del Llano de la Consolación, que las afirman sobre el suelo. A los cuadrúpedos el protagonista humano tiende las manos, llegando a veces a tocar los belfos. Las figuras en pie pertenecen a los relieves hallados en La Encarnación, en Mogón 


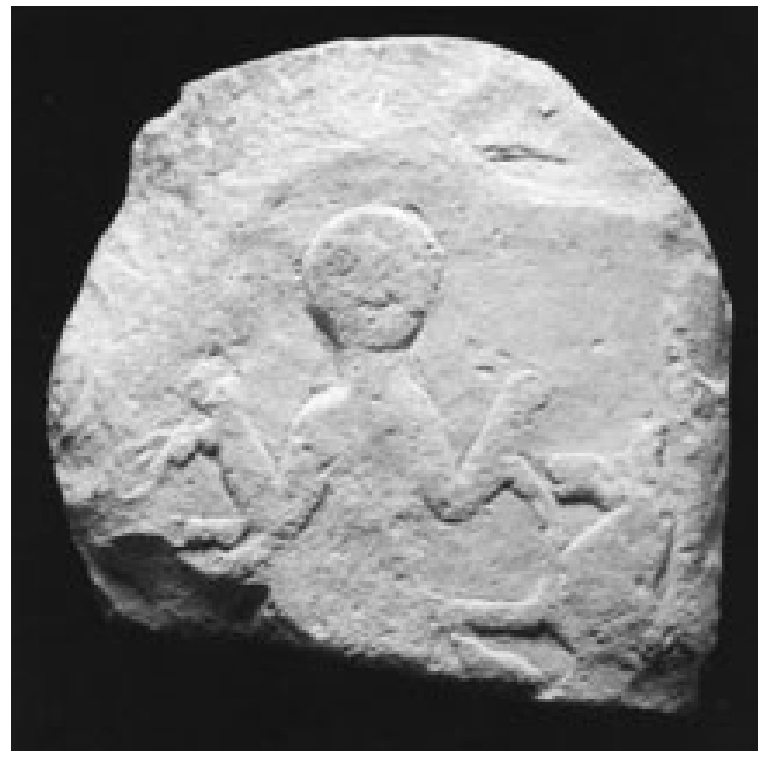

Figura 17. Dios en relación con los caballos. El Pixocol, Balones (Foto Catálogo El Mundo Ibérico una nueva imagen en los albores del año 2000).

(Villacarrillo, Jaén), en El Pixòcol (Balones, Alicante) (Fig. 17), en Sagunto (Valencia) (dos). Las figuras sentadas se hallaron en los bloques localizados en Llano de la Consolación, en Bancal del Tesoro (Lorca, Murcia) (tres), aquí el personaje de uno de los bloque es bifronte (del tercer bloque, desaparecido, apenas hay información) y en Villaricos (Almería) (tres), en dos el varón es bifronte (Fig. 18) (el tercer relieve, en paradero desconocido).

La ejecución de los relieves no es ni mucho menos exquisita, estando trabajados sobre bloques y lastras desiguales, de canteras del lugar, tallados con técnica burda; son aproximadamente troncopiramidales, paralelepípedos, cuadrangulares, e incluso uno, el de El Pixòcol, se plasma sobre placa, cuyo lado superior es de forma semicircular. Las dimensiones de unos y otros no son regulares ni iguales entre sí, la altura oscila entre $70 \mathrm{~cm}$. máximo y $31 \mathrm{~cm}$. mínimo y el ancho y grosor son asimismo muy variables, tendiendo a ser proporcionales a la altura y a la forma. Existe en la bibliografía alguna que otra referencia a su localización en cementerios, como según C. Visedo $(1947,279)$ el de El Pixòcol, pero es dudoso este emplazamiento, en las inmediaciones de la necrópolis está situado el poblado correspondiente y el relieve no fue localizado en un enterramiento. La mayor parte fueron recobrados en zonas ricas en yacimientos iberos o mixtos ibero-púnicos, como los de Villaricos. La bifrontalidad, atestiguada aquí y en la cama del bocado de Cancho Roano, como especificamos, parece estar indicando, en ambos soportes, el mismo ser divino al que someten los hombres la salud de sus cabalgaduras (vid. supra).

M.C. Marín Ceballos y A. Padilla (1997, 481-483), opinan que los relieves se "utilizaron fundamentalmente para invocar la protección del "domador de caballos" divino en el territorio específicamente dedicado a la cría caballar y, secundariamente para delimitar de alguna manera la dehesa caballar, como complemento y refuerzo mágico-religioso del sistema físico de cerramiento..." Es una teoría bastante acertada, siempre dentro de las máximas reservas, al no haberse hallado los bloques, insistimos, en un terreno con definición precisa de su carácter, por lo menos para nosotros (algunos fueron reutilizados en paramentos). Aunque este es un punto a favor de la teoría de los dos investigadores, no se encontraron en poblados, no se encontraron en necrópolis, no se encontraron en santuarios, se encontraron en los campos, pero en las cercanías de poblados, de ahí que pueda pensarse en esas dehesas, de hipotético carácter comunal, -en estas circunstancias los animales deberían estar marcados-, donde pernoctarían las yeguadas o más modestamente las tropillas, unas y otras propiedad de los oligarcas, e incluso los caballos únicos de las personas más humildes. Ya sabemos que para la civilización ibérica nos movemos casi siempre dentro de las especulaciones, de las hipótesis, pero razonando, examinando los datos etnológicos, puede llegarse a un cierto acercamiento a determinados aspectos materiales e incluso a aspectos materiales entroncados con la espiritualidad, como es este el caso. Lo que si es incuestionable es que la figura antropomorfa representada en los relieves

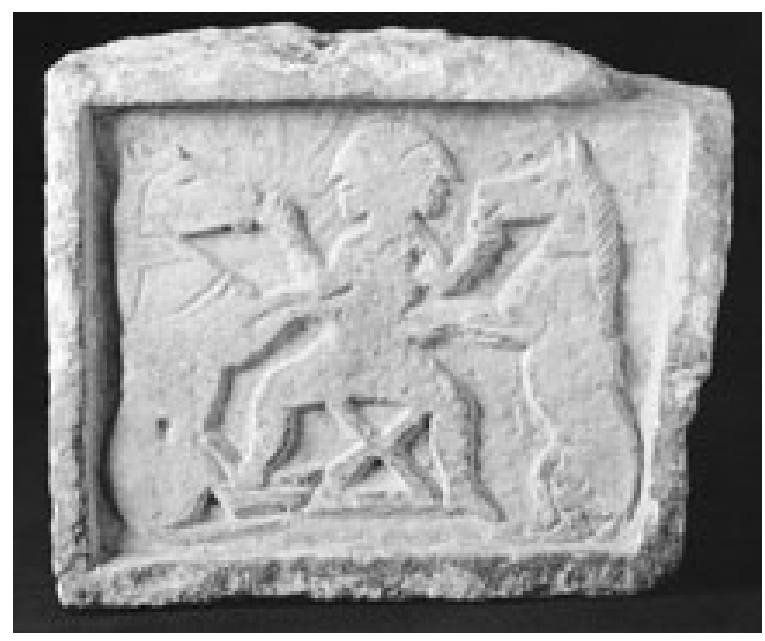

Figura 18. Dios bifronte en relación con los caballos. Villaricos (Foto Ministerio de Cultura). 
tiene que ver con los caballos, no en el ambiente absolutamente terrenal que no tendría ningún sentido en pueblos muy pragmáticos por necesidad, sino en el religioso, en el apotropaico, y volvemos nuevamente a esa misteriosa divinidad protectora de las caballerías ¿la Diosa, el Dios, una divinidad específica asociada a la cabaña equina?

\section{El Dios en inscripciones}

Dos testimonios epigráficos sobre piedra, consisten:

1. En la inscripción sobre el ara de San Lorenzo (La Vid). Parece acertado sugerir que la ermita se levantó sobre un antiguo lugar natural sagrado indígena, un roquedal agreste en el paisaje grandioso del Puerto de Pajares, propio para recibir el hálito de cualquier divinidad, aquí el de una protectora de las caballerías. El ámbito sacro dominaba una de las principales vías de comunicación entre la Asturias cismontana y la Asturias transmontana (Marco, 1998, 488). El dedicante es Iuvlius Reburrus, cuyo gentilicio indígena es característico de los astures, galaicos (es el tercero en número con respecto a los restantes gentilicios catalogados), y menos de los lusitanos y vettones (Marco, 1998, 485). Y el aspecto que interesa a este estudio es que el ara fue consagrada a los Dei Equeunu, que por el conjunto epigráfico conocido hasta ahora recibieron veneración de los montañeses astur-leoneses, entre cuyos linajes igualmente, asentados en terreno tan montañoso, el caballo de monta en general y el de guerra en particular, es paradigma de señorío, de grandeza. $Y$ he ahí pues que no faltaron, no pudieron faltar en un espacio indoeuropeo aún tan aislado como el septentrional, los seres supremos en conexión con los caballos, los Dei Equeunu, de cuyos nombres vernáculos no hay noticia; y su pervivencia, por el testimonio reseñado, llega hasta más allá de la aculturación romana, pues el ara la data F. Marco $(1998,485)$ entre el último tercio del siglo I y principios del siglo III.

J.F. Blanco (2003, 75-123), ha publicado un magnífico estudio sobre la iconografía del caballo entre los pueblos prerromanos del centro y norte peninsulares, al cual remitimos para tal espacio geográfico, donde recoge un muy amplio repertorio de representaciones de équidos en soportes variados. Esta extensa aplicación del caballo a la decoración es prueba de la tan repetida aceptación de este noble animal entre las tribus de mitad norte, equiparable, evidentemente, a la que igualmente tuvo entre las demás tribus peninsulares.

2. En el pedestal de una escultura, que tal ver fuera de un caballo, así es sugerida por W. Grünhagen (1976, Fig. 2) en su reconstrucción, que recoge una inscripción en la que $L$. Aelius Fronto dedica a Dis Pater un caballo con su establo. La alusión al establo indica que la ofrenda consistía en un animal vivo. Acerca de esta inscripción el mismo autor es partidario de que encarna el sincretismo del dios infernal itálico, equivalente a Hades, con una divinidad turdetana, igualmente de carácter infernal, a la que como al dios itálico se le ofrendaban caballos; su nombre, como es habitual, no ha llegado a nuestros días (Grünhagen, 1976, 226). Podía tratarse de una prueba de la vinculación del caballo con la probable deidad infernal turdetana, o bien de que se le ofrecían aquellos bienes animales de mayor valor. Con respecto al sincretismo, las pinturas siguientes refuerzan el papel del caballo como animal al servicio de Hades: en el Mediterráneo, en la pintura de la tumba I de Vergina, fechada entre los años 340-330 a.C., Plutón, el Hades de los romanos, raptó a Perséfone en un carro tirado por caballos (Pollitt, 1989, 308, Fig. 204). En una crátera de volutas del Pintor de Baltimore, fechada en torno al 340-330 a.C., se pintó a Heracles en la ultratumba delante de Hades entronizado y debajo la llegada de una cuadriga conducida por un auriga con gorro frigio, y una segunda cuadriga en el cuello de la crátera, dirigida por un demonio femenino (Pugliese Carratelli, 1990, 228, fig. 342).

La inscripción, recuperada en Munigua (Sevilla), es la única que consta con tal contenido en las provincias del Imperio y en todos los tiempos romanos.

\section{SANTUARIOS}

A los caballos hay que cuidarlos y situarlos bajo la protección de los dioses, igual que se orientaban en las sociedades de lberia todos los actos de la vida. Por tanto los encomendaban a una divinidad, y a cuál mejor que a aquélla que en gran medida atendía todos los aspectos de la vida y de la muerte, a la Diosa Madre y/ o a su paredro, el Dios de la Atmósfera, de los Cielos, de la Guerra, o en otro caso a ciertos entes divinos de carácter masculino o femenino, dedicados desde épocas arcaicas a favorecer a determinados animales, entre ellos desde luego a los caballos. Estas divinidades, en las áreas del sureste y Alta Andalucía se las adoraba, además de en los pro- 
pios poblados y en los hogares, en santuarios, algunos panibéricos, situados, como viene a ser aproximadamente tradicional, en áreas sacralizadas desde épocas remotas. Y una apreciación obligada, aunque es bien conocida, en ningún santuario han aparecido las estatuas, los ídolos a través de los que se manifestaban los dioses a los que se les adoraba en tales ámbitos. Al respecto de la ausencia de pruebas tangibles de las deidades pudiera ocurrir que hubieran desaparecido por el paso del tiempo; o pudiera ocurrir que no fuera necesario patentizar físicamente a la deidad o deidades, bien porque eran consideradas demasiado trascendentes como para adecuarlas a presencia humana, o bien porque estaba la esencia divina fuertemente arraigada en las mentes, en las creencias de los devotos, aunque esta idea parece excesivamente sofisticada para tiempos tan primitivos. Y piénsese en el aniconismo peninsular, difícil de explicar. Si bien acaso este aniconismo es producto de la desaparición, por motivos múltiples, de los viejos ídolos representación de las divinidades, adorados con veneración por generaciones y generaciones de fieles, muchos de los cuales podrían remontar a tiempos muy antiguos y ser incluso de madera $u$ otro material perecedero, no sabemos.

El santuario de El Cigarralejo (Mula, Murcia), datado en el siglo IV a.C., y con vigencia por lo menos hasta el siglo II a.C., es por excelencia el que con más certeza pudo ser uno de los lugares sagrados, en el que se revela a las ofrendas, oraciones y ritos de los fieles, una divinidad protectora/patrona de los caballos, de su fertilidad, de su energía, de su salud. Mas ello no obsta para que en otros santuarios no tan "especializados", los dioses titulares atendieran idénticas peticiones, o bien las deidades custodias de los caballos tuvieran un altar, un nicho, en aquéllos de carácter más general. Sea un dios o una diosa o ambos, lo cierto es que se organizó un santuario en su honor: el de El Cigarralejo (Cuadrado, 1950). En el suelo del primitivo santuario, cuya cronología oscila entre el siglo IV a.C. y la segunda mitad del siguiente, se descubrieron ciertas cantidades de estatuillas, la casi totalidad de los exvotos, éstos sobre arenisca local, los cuales, en su mayoría, representaban équidos (varios fueron retirados desperdigados por la ladera, e incluso en el encachado de una tumba de la cercana necrópolis fue reutilizado un carrito con un tiro de dos bestias, vid. infra). Los animales tienden a estar parados. Ciertos ejemplares van perfectamente equipados con arnés completo (Fig. 4); otros componen grupos de macho y hembra; un exvoto representa a la hembra de asno con su pollino, y otro una ye-

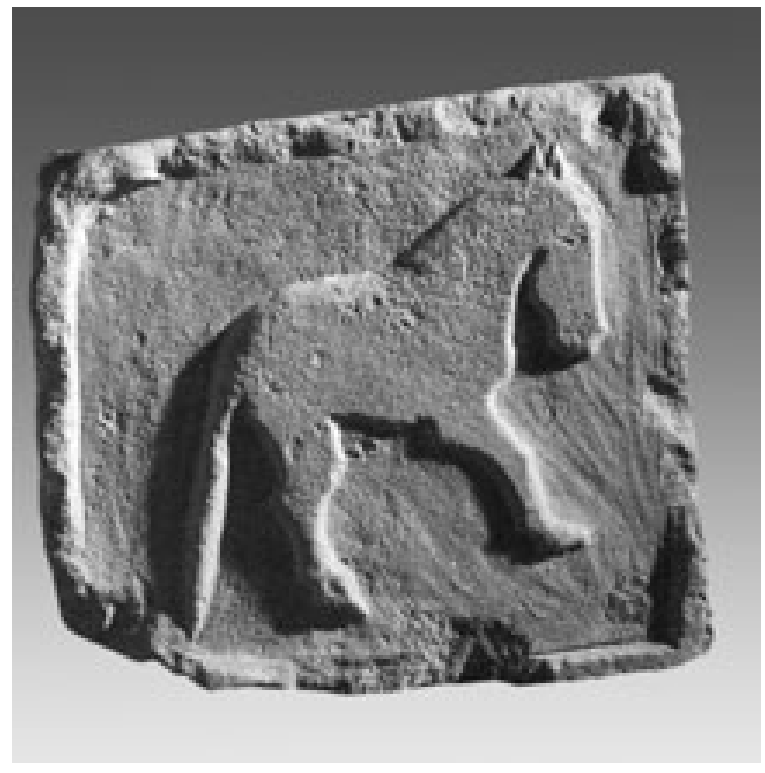

Figura 19: Exvoto del santuario de El Cigarralejo (Foto P.A. Saura. Escultura Ibérica. Revista Arqueología).

gua con la cría; igualmente se han reunido cabezas. Fueron contabilizadas alrededor de doscientas figurillas y tan sólo diecisiete eran de seres humanos completos, además de algún miembro; también había alguna que otra fusayola, adornos de metal y armas.

Los caballos se hallan en relieve (Fig. 19), bulto redondo (minoría), grabado, o en combinaciones diversas de las tres técnicas, por medio de línea esquemática. Son piezas de pequeño tamaño en las que domina la perspectiva frontal. Los relieves suelen ser planos, toscos, recortados, en los que los rasgos protuberantes componen la figura del animal; otras placas han sido recortadas por la silueta, dejando materia sin separar en la zona comprendida entre las patas. Sin embargo todos obedecen a los mismos conceptos sociales y religiosos: en primer lugar, y como escribió E. Cassirer, en la vida de las interrelaciones personales y en la mente del hombre particular, los símbolos juegan un papel necesario "el hombre no se enfrenta con la realidad de un modo inmediato y directo... Se ha envuelto a sí mismo en formas lingüísticas, en imágenes artísticas, en símbolos, de tal manera que ve las cosas a través de la interposición de esa urdimbre simbólica". Y en segundo lugar las gentes acudiendo al santuario propiciaban con la ofrenda de los exvotos (manejo de los símbolos),-hay que pensar asimismo en otros presentes vegetales y animales-, la protección del dios/a del santuario hacia el caballo o caballos del oferente y por extensión, repetimos, hacia sí mismo que lo monta o comercia con él. 


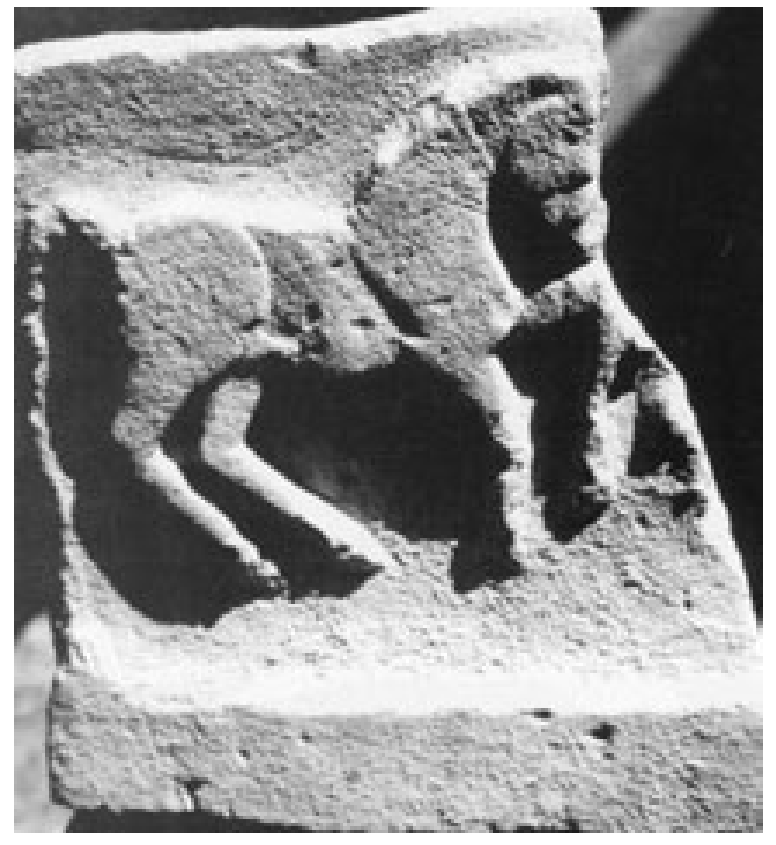

Figura 20: Exvoto de Luque, Córdoba (Foto F. Fernández Gómez, 2003, 53, lám. II).

Evidentemente es una conjetura, en realidad como la mayoría de lo escrito, pero ¿no acudirían a los santuarios con mayor asiduidad precisamente aquellas personas que poseían menos caballerías, y éstas en muchos casos sólo de labor?; para este segmento poblacional el perder su animal representaba siempre un motivo de intensa inquietud, y su pérdida un mal irreparable que incluso podía llevarlo a la ruina, y desde luego seguro que a una multitud de problemas de difícil solución. No hay más que ver cómo los campesinos actuales más desfavorecidos, cuando algún ejemplar de su ganado, vaca, cerdo, comienza a tener síntomas de enfermedad, lo cuida con la mayor atención y su salud quebrantada es motivo de preocupación para todos los miembros de la familia.

Y de la misma manera se nos ocurre pensar en cómo recibían las divinidades los dones ¿ocurrió que el pueblo no tuvo entrada a las cuevas o edificios, que pudieran ser considerados como el sancta sanctorum?, en este caso serían sólo accesibles a los servidores sagrados, ¿eran entregados a los dichos servidores de las divinidades? ¿los depositaban a la entrada?, imposible saberlo, únicamente sí es notorio que los santuarios, en cueva o de obra, eran todos de muy pequeñas dimensiones, no susceptibles de dar cabida a un número alto de personas.

Y en contrapartida a tanta atención al caballo, o tal vez por su misma calidad, por lo menos algunos grupos tribales septentrionales sacrificaban caballos de los cuales bebían la sangre de las venas, como expresan Horacio (Carm. III, 4,34) y Silio Itálico (III, 360), aludiendo a los concanos, pueblo que al parecer vivió en el norte. El motivo de este acto sacrificial lo ignoramos, pero basándonos en el conocimiento que se tiene de pueblos, incluso primitivos actuales, mediante actos de magia el beber la sangre de un ser, entre otros aspectos a los que no nos es dado llegar, equivale a apropiarse de su poder, de su vitalidad. Estrabón (III, 3,7), por su parte, escribe que los montañeses del norte "sacrifican a Ares (el dios de la guerra nativo, identificado por el Geógrafo con Ares) un chivo, cautivos de guerra y caballos". Por estas noticias y por otras, -nunca totalizamos por razones de espacio, sino que trazamos una muestra-, en ningún momento ha podido pensarse, con respecto al caballo como en un animal sagrado, o como un dios caballo (Duval, 1957, 42), porque los dioses no eran sacrificados, se les ofrecían sacrificios. Sacrificios de caballos están bien documentados en diversos ámbitos occidentales, tanto en la literatura como en los elementos materiales (vid. supra, infra). El caballo y es mucho, fue un insigne servidor del hombre, del mismo modo, según determinados mitos, fue servidor de los dioses, pudo tener relación con el Más Allá en cuanto a otros mitos en los que se contempla el transporte de las ánimas en carros, éstos con tiros de corceles, etc.

\section{CABALLOS EN RELIEVE O INCISOS SOBRE PLACAS/BLOQUES DE PIEDRA, QUE ATESTIGUAN LA EXISTENCIA DE SANTUARIOS NO LOCALIZADOS}

M.C. Marín Ceballos y A. Padilla informan en su magnífico trabajo sobre el significado del "Domador de Caballos" $(1997,483)$ que en el lugar conocido como la Cuesta de Velillos se encontraron cerca de setenta representaciones de caballos, consistentes en relieves sobre placas y esculturas, y citando a P. Rodríguez, F. Peregrín, R. Anderica (1983, 756-757), señalan que algo semejante ocurre en el lugar denominado Llanos de Silva (Granada).

E. Cuadrado y E. Ruano (1989) publicaron una serie de placas/bloques con grabados y relieves, sobre una superficie previamente preparada (algunos están decorados por dos caras, anverso y reverso, otros pudieron estar policromados), representado caballos, éstos con precariedad de detalles anatómicos, en distintas actitudes, parados, al trote, al galope. F. Fernández Gómez 
$(2003,21)$ ha sacado a la luz un nuevo conjunto de las mismas características y contenido (Fig. 20), y recoge los estudios de E. Cuadrado y E. Ruano. Todos proceden de dos colecciones privadas (Rabadán, Mársal). F. Fernández Gómez indica que las placas/bloques, diecisiete de Alhonoz y sesenta de Sanlúcar de Barrameda, pertenecen a un único yacimiento, -están trabajadas en la misma piedra, caliza blanda, porosa- que, con un cierto sentido, consistiría en un santuario, del que no se sabe su situación concreta, en la localidad de Luque. El santuario podría ser similar a los de El Cigarralejo y Pinos Puente (Fernández Gómez, 2003, 37), dedicado a un ser sagrado al que le ofrendaban exvotos con figuraciones de équidos en distintas actitudes. Los relieves, fuera de todo contexto, no han podido datarse, pero si presuponemos la existencia de un santuario similar a los aludidos, su cronología podría acercarse a la de ellos; abundando, la mayor parte de los santuarios ibéricos y citamos dos de los más emblemáticos en la provincia de Jaén, Collado de los Jardines y Castellar de Santisteban, funcionan a pleno rendimiento en el siglo IV a.C., uno de los momentos álgidos de la civilización ibérica. En cualquier caso las placas-bloques conteniendo équidos son testimonio ineludible de la existencia de un lugar santo en el que se ofrendaban los repetidos exvotos, en el transcurso de unos imprecisos rituales religiosos, a manera de los que pudieran realizarse en el santuario de El Cigarralejo. Hay noticias de que fueron más los ejemplares recogidos por la cuadrilla de gitanos expoliadores de yacimientos que vendió los estudiados al mercado de antigüedades, pero se han desperdigado por las vitrinas de los mal llamados coleccionistas. Las placas son de dimensiones diversas, desde una la $n^{\circ} 38$ con 14 x 13 x 5 cm. (Fernández Gómez, 2003, 29, Fig. 38, Lám. XXXVIII), hasta la n 15 con $59 \times 27 \times 11$ cm. (Fernández Gómez, 2003, 25, Fig. 15, Lám. $\mathrm{XV})$. Las representaciones son ciertamente precarias, hasta el punto de que F. Fernández Gómez (2003, 36-37), descarta la existencia de un taller anejo al santuario y acertadamente opina que, admitiendo su poco valor artístico, en cada bloque pudo ser trabajada la figura del animal por el mismo devoto, teniendo algunos mejor mano, mayor capacidad que otros; e incluso es posible que por un ritual que desconocemos se elaborara la figura en las cercanías del sitio donde iba a depositarse la ofrenda, tal vez realizando los conjuros, oraciones, rituales, etc., que vinieran al caso ¿es que así era más efectivo el sacrificio?

Según bien indica D. Vaquerizo, (1997, 322, Fig. 8), que igualmente ha estudiado al- gunos de los ejemplares de Luque, esta clase de exvotos en placa/bloque con caballos se encuentran igualmente en la Grecia antigua, y muestra dos placas con sendos équidos en marcha a la izquierda, procedentes del santuario de Artemisa de Esparta. Y continúa escribiendo que es una manifestación común a todo el Mediterráneo y que surge tanto en el ámbito griego como púnico. El autor citado cree que las placas/bloques ibéricas responden más a un impulso cartaginés que griego. Opinamos que la concepción religiosa ibera no fue adoptada ni de unos ni de otros, pero sí pudo asimilarse el tipo de soporte físico, las placas/bloques, y la grafía foránea para un concepto religioso simbólico que los iberos ya desarrollaban ampliamente, el de los exvotos, entre ellos los de bulto redondo, sean zoomorfos o antropomorfos (Torreparedones (Córdoba), Collado de los Jardines, Castellar de Santisteban, EI Cigarralejo, Nuestra Señora de la Luz (Murcia), La Serreta, etc.). Sí es factible que ocurriera, no obstante, el aceptar la representación de aquel concepto que querían ofrecer a la divinidad, en placas/bloques líticos. Es más fácil de elaborar y menos costoso un relieve o una incisión en placa/bloque, que un bulto redondo sea en metal a la cera perdida o sobre piedra, y más fácil aún plasmarlos en madera, -desaparecidos-, que con toda probabilidad se producirían.

\section{EL CARÁCTER FUNERARIO DEL CABALLO. LA HEROIZACIÓN ECUESTRE}

Sobre este tema publicamos hace ya casi 50 años un trabajo (Blázquez, 1963, 405-423, Figs. 1-20). En la actualidad, nuevo material arqueológico permite ampliar considerablemente el contenido y la interpretación del tema, que en 1954 puso de moda en la investigación mundial el hispanista E. Benoit, en un libro que marcó un punto de partida para el tema y que no ha sido superado aún (Benoit, 1954). El tema ya lo había abordado el investigador galo años antes en otros trabajos (Benoit, 1950). Nosotros, en 195758 , dedicamos un trabajo al papel del caballo en las creencias de ultratumba entre los etruscos (Blázquez, 1957-1958, 31-68, Fig.5). El carácter funerario del caballo había sido tratado por la investigación muchos años antes referido a Grecia, en un famoso y fundamental trabajo, por $\mathrm{L}$. Malten (1914).

Se trata, por lo tanto de una creencia mediterránea y no exclusiva del mundo galo o hispano (Blázquez, 1977, 261-277). 


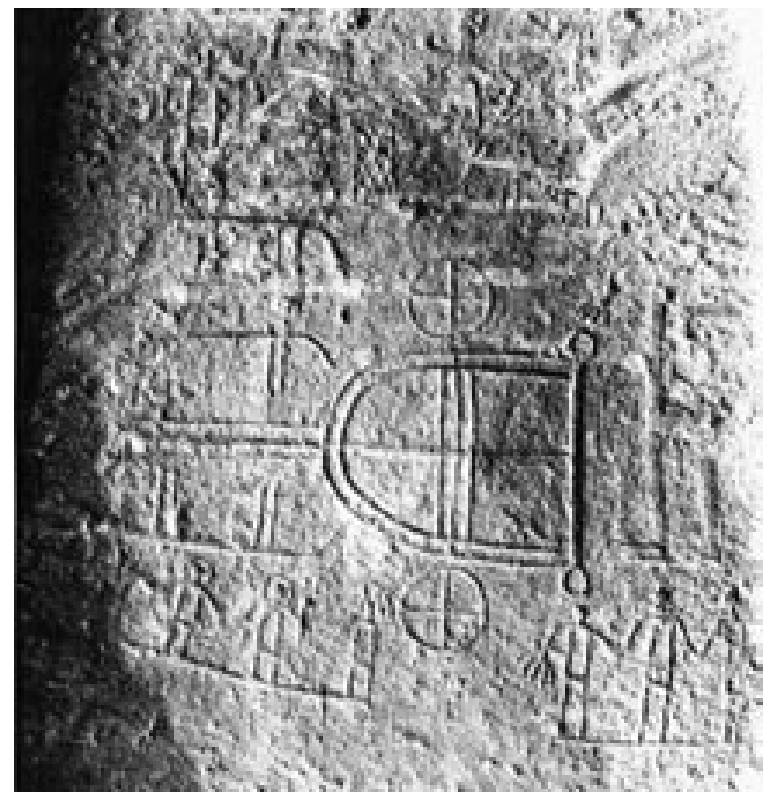

Figura 21: Estela de Ategua (Foto M. Fernández Miranda, R. Olmos).

Los testimonios más antiguos de la vinculación del caballo con las creencias funerarias entre los pueblos prerromanos de Hispania podrían ser los carros tirados por animales, que pudieran ser équidos o bóvidos, representados en las estelas del período orientalizante (Barceló, 1988, 189-200. Fernández Castro, 271-309; Celestino, 2001, 229-232). Veintiuna estelas (Fig. 21) tienen representaciones de carros. Todos los carros ofrecen una homogeneidad formal. Todos representan la misma perspectiva. Faltan los carros en las estelas aparecidas en la Sierra de Gata y en sus estribaciones. En la zona media del Tajo, en las zonas que corren paralelas al río, han aparecido seis representaciones de carros entre 20 estelas catalogadas, lo que significa un $30 \%$ del total. El carro se introdujo en las estelas sin modificar sensiblemente el primitivo esquema de las mismas. Los carros más antiguos serían los de la estelas de Valencia de Alcántara I y II y Torrejón el Rubio I, que se añaden en la zona inferior de las lápidas. Esta posición inferior será la que ocupe, generalmente, a lo largo de la serie. Si excepcionalmente se varía, es para colocarse en cualquier otra zona de la losa.

Mayor relevancia ofrece el carro en las estelas de Solana de Cabañas, Zarza de Montánchez y las Herencias I. Lo importante no es el carro, sino la presencia del guerrero, quizás por vez primera. A partir de ahora el carro va unido al guerrero siempre. La estela de Torrejón el Rubio podría ser un monumento de transición, donde el carro se añadió con posterioridad, como lo indica la técnica del grabado. El carro se grabó con más cuidado.

El carro se generalizó entre los valles del Guadiana y del Zújar, con 10 representaciones de carros entre las 30 del grupo. Estas estelas se caracterizan por el alto grado de esquematismo en las figuras. Se acentúa el aislamiento del carro con respecto a los dibujos. En estelas del valle del Guadalquivir tan sólo se conocen 3 estelas con carros, entre 25. En la estela de Carmona, el carro se ha considerado de cuatro ruedas y tirado por bueyes. En realidad es un carro de dos ruedas, como todos los restantes. En la estela de Écija IV, el carro se encuentra a los pies del guerrero. En las estelas I, II y III de la misma localidad, pudo representarse también el carro, dada su analogía con Écija IV, pero se ha perdido la parte inferior de la estela. La estela más importante es la aparecida en Ategua, por ir acompañado el carro de una danza fúnebre, dato muy importante para interpretar el verdadero carácter del carro.

Igualmente se grabaron carros en las estelas de Capote y Fuentes de Cantos, halladas en áreas marginales a las anteriores.

En el estudio del carro de las estelas se ha prestado especial atención a su posición. La región del valle medio del Tajo se ha subdividido en, al menos, dos focos independientes, aunque al parecer responden a características bastante homogéneas: Sierra de Montánchez y grupo de Valencia de Alcántara, donde están incluidas las estelas de Alburquerque y de Brozas, además del foco de Torrejón el Rubio, muy distanciado del resto de los documentos. Se obtiene una idea muy clara del simbolismo del carro, que siempre se coloca a los pies del guerrero. En estelas de la Sierra de Montánchez se introducen elementos foráneos, como es el carro siempre acompañado del guerrero en la estela de Solana de Cabañas, Zarza de Montánchez y Las Herencias I, las tres de composición muy similar y con carros. Los carros de Zarza de Montánchez y Las Herencias I son muy similares a las anteriores.

Es importante señalar que los carros de las estelas de Ategua y Zarza Capilla III son semejantes a los anteriores. El carro se representó independiente de los motivos principales, guerreros, armas y objetos de prestigio. La novedad radica en que el carro centra otra escena con personajes que rodean al principal, en una danza fúnebre ritual. En ambas estelas, el guerrero, ya difunto, está colocado junto al extremo de la caja del carro, como intentando subirse al mismo. En las estelas de Ategua y de Zarza Capilla III, se representaría una danza fúnebre 
ritual del tipo de las pintadas en vasos griegos arcaicos, como sobre un ánfora eubea hallada en Eretria, o sobre un cántaro beocio, o sobre una hidria ática hallada en Onalatos, del pintor Onalatos (Boardman, 1998, 42, Fig. 84; 48, Fig. 99; 89, Fig. 188).Este mismo tipo de danza fúnebre se repite en Etruria, en un relieve de Chiusi, fechado entre el primer y el segundo cuarto del siglo VI a.C. (Bianchi Bandinelli, Torelli, 1986, Fig.55). El origen de estos carros hay que buscarlo en el Oriente, al igual que el de los escudos con escotaduras en V (Blázquez, 1992, 161-182. Quesada, 1993, 179-188). Se ha descartado que fuera un carro de guerra del tipo de los representados en Chipre (Karageorghis, 1968, 260, Fig.100. Spiteris, 1970, 92-93), de época arcaica o del Oriente; Saktshageuzu de estilo arameo, 730-700 a.C, con caza de león; Sendjisli de estilo neohitita medio, 632-610 a.C., de guerra; Karkemish, igualmente de guerra, de la segunda mitad del siglo VIII a.C. (Akurgal, 1969, 58, Lám. 23b; 101-102, Fig. 66; 107-109, Fig. 86; Akurgal, 1962, 115, Lám. 124); también cacería del león del ortostato de Malatnya, de estilo asirizante, fechado entre los años 850-700 a.C. (Akurgal, 1962, 113, Lám. 105). Tampoco son carros de transporte ni carros votivos, como algunos hallados en los santuarios ibéricos. Parece más probable que sean carros funerarios, como parece indicar la danza ritual fúnebre representada en la estela de Ategua, y la presencia del espejo que acompaña al carro, representado en estelas (Celestino, 2001, 163-169), en Torrejón el Rubio, Zarza de Montánchez y en Fuentes de Cantos. Un espejo se recogió en la sepultura de La Aliseda, y otro en una sepultura de Huelva datada en el siglo VI a.C. El espejo tiene carácter fúnebre en estelas del Oriente, como en las estelas funerarias con esposos procedentes de Marash, de estilo arameizante-hitita de finales del siglo VIII a.C. o de comienzos del siguiente; en una segunda de la misma procedencia y fecha, con escena de familia (Akurgal, 1969, 132, Lám. 26; 133, Lám. 28; 1962, 118, Lám. 139; 1962, 119, Lám. 129; Bittel, 1976, 276, Fig. 315; 278, Fig. 316).

Los carros de las estelas hispanas parecen ser semejantes al carro etrusco de Monteleone de Spoleto, fechado en el siglo VI a.C., hallado en una tumba de cámara que, con seguridad, es un carro de parada, a juzgar por las representaciones lujosas, decorado con escenas del ciclo troyano (Spencer, Bartoloni, 1977, 111, Láms. 105-107. Poulsen, 1962, Figs. 379-382), o el carro de Castel San Marino, conocido por las placas de revestimiento decoradas con Zeus que golpea a un gigante y con Zeus con cetro en la mano (Spencer, Bartoloni, 1977, 112, Láms. 108-109. Poulsen, 1962, Figs. 385-386). Los carros, los escudos con escotaduras en $\mathrm{V}$ y los espejos proceden del Oriente. Los carros hallados en Hispania proceden de tumbas y, por lo tanto, no se les puede negar un carácter funerario, igual que a los caballos, a partir del siglo VII a.C., como al hallado en La Joya, del que se trata más adelante. Las escenas de Ategua y de Zarza Capilla III se han comparado con las pinturas sobre los vasos, de carácter fúnebre, del periodo geométrico, como los representados en un vaso ático fechado en los siglos VIII-VII a.C., con desfiles del carros de dos ruedas que aquí son, con seguridad, los que intervienen en los juegos fúnebres organizados a favor del difunto, como los escritos por Homero en el último libro de la llíada, en honor de Patroclo. El carácter fúnebre de estos carros no se puede dudar, pues se representan las lamentaciones y la exposición del cadáver sobre las kline (Robertson, 1959, 3839). En las estelas hispanas, aunque se representan danzas fúnebres una vez, de varones y de mujeres, en Ategua, no parece aludirse a carreras de carros de carácter funerario. Se ha interpretado el simbolismo funerario de las estelas de Ategua y de Zarza Capilla III como una nueva concepción del ritual funerario en Occidente hacia el siglo VIII a.C. o aún antes. Se ha concedido mucha importancia, y creemos que la tiene, a la escena sobre lidita aparecida en Cancho Roano, con una simbología acorde con la expresada en estas estelas. La escena representa un carro de caja rectangular y de dos ruedas tirado por un caballo, que transporta un ánfora que, sin duda, contenía las cenizas del difunto. Detrás marcha un varón. En la parte superior se representa, verosímilmente, al difunto yacente rodeado de alimañas, transportado hacia el Más Allá (?) (Blázquez, 1983, 439, Fig. 146). Se ha propuesto que esta simbología podría expresarse en las dos últimas estelas mencionadas, que indicaría una perduración de la idea.

El carro tirado por caballos se ha interpretado como idea llegada al Occidente desde fuera, junto a otros objetos de prestigio, armas, espadas y cascos, ligada a un ritual fúnebre. No se pueden relacionar los carros con ideas de un viaje a ultratumba, que en los siglos en que se fechan las estelas, es inconcebible.

En Etruria, un viaje a ultratumba está excluido antes del siglo $V$ a.C., estelas felsinas. Los pueblos de la Hispania prerromana no debían estar más avanzados en las creencias fúnebres. En Etruria lo equivalente a las estelas hispanas, son las estelas con guerreros, armados con 


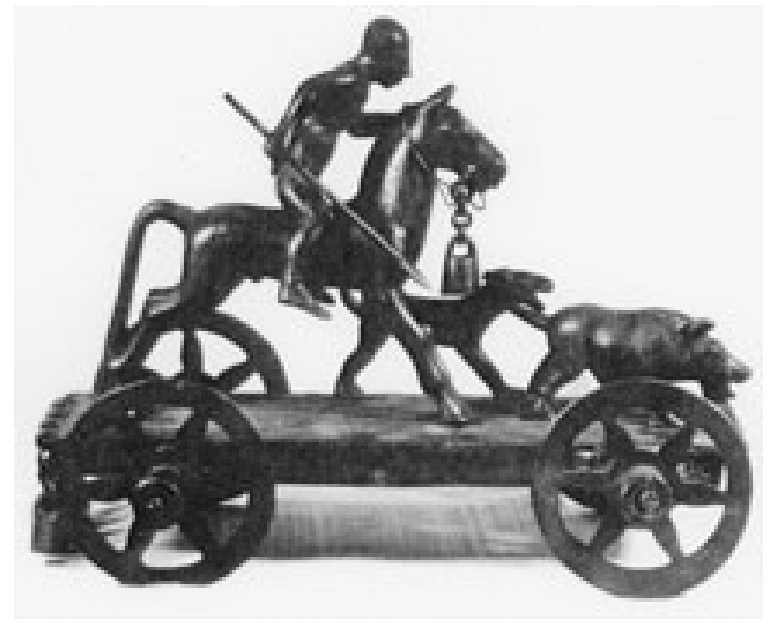

Figura 22: Carro de Mérida (Foto M. Fernández Miranda, R. Olmos).

lanza y espada en relieve, labrados en piedra, como el de Volterra, fechado en torno al 550 a.C. (Sprenger, Bartoloni, 1977, 101, Fig. 67) y otros parecidos, como la estela sepulcral arcaica con guerrero inciso e inscripción, armado con bipenne, hallada en Vetulonia (Pallottino, 1984, Lám. I), o la de Lartes Nune, fechada en los últimos decenios del siglo VI a.C., procedente de Florencia, con guerrero armado con lanza y con hacha (Camporeale, 2000, Fig. 79). Este tipo de estelas con guerreros con lanza es frecuente en el Ática (Ritcher, 1961, 1970). Se ha pensado que son guerreros heroizados

Un pequeño carro de terracota apareció depositado en el interior de una urna hallada en una tumba entre Mairena de Alcor y Alcalá de Guadaira (Sevilla), datada a comienzos de la Edad del Bronce (Blázquez, 1963, 405-406). La costumbre de depositar pequeños carros en las urnas, es costumbre documentada en Grecia, Etruria y otros lugares. No se los ha interpretado como un simple objeto depositado en las tumbas, sino como objetos simbólicos que indican la ligazón entre el caballo y la ultratumba. Aludirían al transporte del difunto en carros hasta la sepultura. En la tumba $n^{\circ} 77$ de la necrópolis de Les Corts de Ampurias, se depositaron dos pequeños caballos de terracota. La necrópolis se fecha en torno al 200 a.C. Esta tumba podría ser de un griego. El carro hallado en una tumba de Mérida (Fig. 22) podría tener un carácter fúnebre, como admite F. Benoit. La caja sigue modelos chipriotas (Blázquez, 1955, 41-60, Figs. 1-4; Blázquez, 1976, 10-14, Láms. 1-II; 1977, 345-359. Fernández-Miranda, Olmos, 1986, 122-123). En el carro de Mérida se representa la caza a caballo de un jabalí ayudado por dos perros. La caza y el jabalí son animales de carácter funerario. El carro de Mérida se fecha entre los siglos V-IV a.C.

Un jarro fúnebre de Huelva, del siglo VII a.C., refuerza el carácter funerario del caballo, la boca es una cabeza de ciervo, animal funerario, y el asa un prótomo de caballo (Blázquez, 1988, 214, Fig. 9).

En la necrópolis tartésica de La Joya, en Huelva, restos de carros han aparecido en las tumbas nos.17 y 18 (vid. supra). Al lado del de la tumba $\mathrm{n}^{\circ} 17$ se descubrieron dos cabecitas de felino que decorarían los cubos o el exterior del suelo. En cuanto a la estructura las ruedas, dos, debían ser de madera y no se hallaron llantas, ni abrazaderas, ni refuerzos, lo que hace suponer que fueron previamente desmontadas. J.P. Garrido, el investigador de la necrópolis, supone que eran de cuatro radios. El extremo de la lanza llevaría un cubilete de plata. Otras piezas son un pasarriendas, que iba en la parte superior de la caja, ésta estaba reforzada por dos tiras de bronce. Las cintas caladas, decoradas con palmetas de cuenco, serían los elementos decorativos quizás de la parte superior de la caja. El carro de esta tumba parece más bien de parada y no el fúnebre para conducir al muerto a su última morada terrenal, que por lógica debía ser alargado y mejor de cuatro ruedas, pero aún así es aventurada cualquier hipótesis. Y había un par de bocados de caballo (Garrido, Orta, 1978, 63-124, Figs., 33-75, Láms. XXXIV-LXXIII). La decoración de cabezas de felinos (Blech, 1993, 261-262, Lám. 22) se repite en la parte trasera de la caja del carro, en los mencionados carros de Saktshageuzu, de Sendjirli y en uno de los dos carros de la tumba $n^{\circ} 79$, siglo VIII a.C., de Salamina de Chipre (Karageorghis, 1969, 78-86, Láms. 36-39), decorada la caja con cinco cabezas de león. Uno era un carro de guerra y el otro un coche fúnebre. En el dromos de esta tumba $\mathrm{n}^{\circ} 79$ se colocaron dos carros fúnebres: uno tirado por cuatro y otro por dos cuadrúpedos ¿caballos?. Los esqueletos de la primera cremación fueron dispersados por la segunda. Un carro, se encontraba en perfectas condiciones y el fúnebre había perdido las ruedas y la pértiga.

En la necrópolis de Salamina de Chipre han aparecido otros carros, como en el dromos de la tumba $\mathrm{n}^{\circ} 1$ (Karageorghis, 1969, 27, Lám. 8 ), se hallaron un carro y los esqueletos de dos caballos. La costumbre del sacrificio de un caballo era ritual practicado frecuentemente. Se documenta, además de en Salamina, en Palaepaphos. En el dromos de la tumba $n^{\circ} 2$ de Salamina se halló un asno junto a los restos de un carro y otro asno aislado (Karageorghis, 1969, 
31-32, Fig. 4, Láms. 9-10). En la tumba $n^{0} 1$ se hallaron, junto al carro y los caballos, los esqueletos de personas, que tal vez eran criados libres o esclavos, sacrificados al mismo tiempo que su amo, para servirle en la ultratumba, ritual fúnebre practicado en Chipre: Lapithos, a comienzos del primer milenio a.C.; en Tamassos, en el período arcaico y en el palacio de Vouni en época clásica. Sirvientes sacrificados se documentan en la Grecia Micénica. Homero menciona el sacrificio de nueve jóvenes troyanos sacrificados en la tumba de Patroclo, sacrificio imitado en Etruria en la tumba del François, de finales del siglo II o de comienzos del siguiente (Pallottino, 1952, 115. Steingräber, 1984, 380-381, Lám. 183). Estos rituales se practicaban entre los escitas, asociados al sacrificio de un caballo. En la tumba $n^{\circ} 9$ se han recogido cabezas de asnos sacrificados. En las tumbas reales de la necrópolis de Salamina se sacrificaban caballos y no asnos. Los carros tirados por dos asnos eran coches fúnebres sin caja, que tenían un suelo plano con dos ruedas. Los modelos de estos carros están bien documentados en terracotas del período arcaico de Chipre. Están representados en la pintura vascular griega de los períodos arcaico y clásico. Sin embargo, los prototipos de los carros chipriotas proceden del próximo Oriente (Amadasi, 1965). La monumental tumba $n^{\circ} 47$ de la necrópolis de Salamina fue utilizada en dos ocasiones: la primera a finales del siglo VIII a.C. y la segunda a comienzos del siglo VII a.C. En la primera cremación, en el dromos, se sacrificaron dos caballos colocados junto al carro. En el dromos de la segunda cremación se sacrificaron seis caballos en honor del difunto durante el sepelio. Cuatro pertenecían a una cuadriga y dos a una biga. La segunda cremación no dispersó los esqueletos de la primera cremación (Karageorghis, 1969, 50-54, Figs. 5-7, Láms. 16-17). En el dromos de la tumba $n^{\circ} 50$ se depositaron dos caballos sacrificados (Karageorghis, 1969, 58-59, Fig. 10, Lám. 22), un yugo de madera (Crouwell, 1987, 101-118, sobre carros chipriotas de la Edad del Hierro). Al igual que en la tumba $n^{\circ} 47$, no hay huellas de restos del carro. En el dromos de la tumba $n^{\circ} 3$ se hallaron huellas de dos carros con los esqueletos de los caballos (Karageorghis, 1969, 68-69, Fig. 15). Uno de los carros era de guerra y el otro un carro fúnebre. El tipo del primer carro recuerda a los carros micénicos pintados en las cráteras de los siglos XIV y XIII a.C. El segundo carro responde a un tipo conocido en carros de terracota chipriotas. En el dromos de la tumba $n^{\circ} 19$ se depositó el esqueleto de un asno. En tumbas menos monumentales se sa- crificaban asnos y no caballos, sin carros y $\sin$ ofrendas. Estas tumbas pertenecerían a una clase media de nobles o de ciudadanos ricos de Salamina (Karageorghis, 1969, 73, Fig. 19). En el dromos de la tumba $\mathrm{n}^{\circ} 31$ de la misma necrópolis de Salamina, se sacrificaron dos asnos colocados simétricamente (Karageorghis, 1969, 74-75, Fig. 18).

El ritual de las tumbas de Huelva es el mismo que el seguido en Chipre, es decir, el descrito por Homero, con banquetes fúnebres, de los que quedan los platos apilados (Blázquez, 1983, 118, Fig. 72). Las ofrendas, muy numerosas, depositadas en las tumbas, indican que se concebía la tumba como morada del difunto, y que se servía de ellas en la ultratumba. Esta misma creencia es la que había en las tumbas hispanas de Huelva, Peal del Becerro y en las otras con restos de carros. Esta creencia existía en Etruria en la época vilanoviana (Pfiffig, 1975,162-167).

Estas tumbas chipriotas son los prototipos (Blázquez, 2000, 94-103, sobre las relaciones de Chipre y del Occidente) que hay que tener presente para los rituales con carros y con caballos de las tumbas citadas de Huelva y de la de Peal del Becerro. En Etruria también se enterraban los ricos aristócratas con carros. En la tumba Regolini Galassi, fechada en el siglo VII a.C., se han hallado dos carros, uno con dos ruedas, y otro fúnebre de cuatro, con lecho sobre la caja (Boëthius, 1962, 48, Fig. 44). Carros han aparecido en tumbas etruscas del Duce en Vetulonia y en Fabriano (Emiliozzi, 2000). En general, sacrificios de caballos están atestiguados en Grecia. Aquiles sacrificó sobre la tumba de su amigo Patroclo sus caballos (II. XXXIII, 171-172). En la tumba de Cimón, hijo de Milcíades, en época pisistrátida (561-510 a.C.) se sacrificaron sus caballos (también heroon de Lefkandi). En época micénica (Maratón) también se documentan caballos sacrificados en las tumbas. Entre los escitas (Hdt. IV, 71) se sacrificaban los caballos el día de los funerales, al igual que en Tracia (Blázquez, 1963, 410, n. 25). La costumbre de depositar carros en las sepulturas está bien documentada en Galia en la primera Edad del Hierro, y en Tracia (Blázquez, 1963, 408, n. 20).

En Occidente han aparecido otros carros tirados por caballos de carácter funerario.

A la entrada de la cámara sepulcral de Toya se halló un carro con dos ruedas de seis radios (Fernández-Miranda, Olmos, 1986, 49-74, Figs. 12-19). Este carro, datado en primera mitad del siglo IV a.C., a juzgar por las cerámicas griegas, hay que darle el mismo carácter que a las bigas en los dromos de Salamina. No es un 


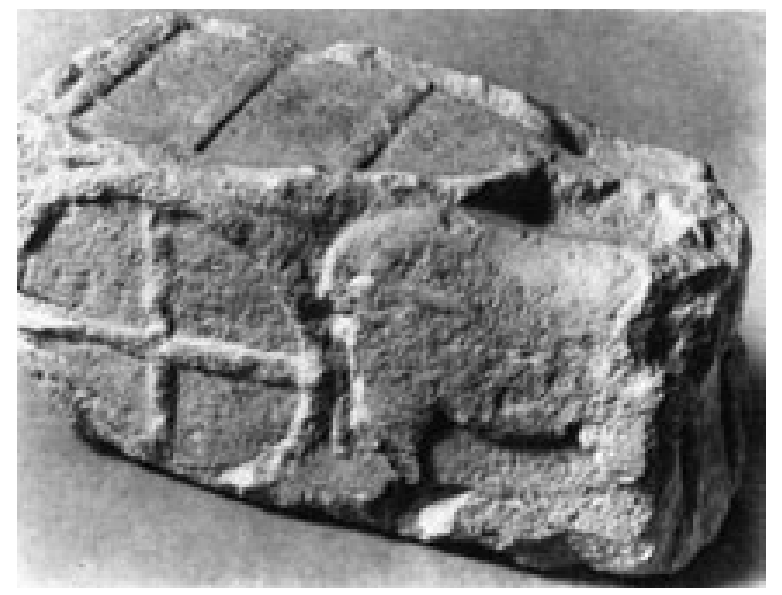

Figura 23: Carro de la necrópolis de El Cigarralejo (Foto M. Fernández Miranda, R. Olmos).

carro de transporte de cadáver. La caja del carro prácticamente no ha llegado, por lo que es difícil de precisar si se trata de un carro de guerra o de prestigio, posiblemente esto último.

Piezas de carro parecidas a las del carro de Toya se hallaron en una sepultura de Galera, y en otra restos de otro carro. En la necrópolis de El Mirador de Rolando se encontraron restos de un carro. Se fecha entre finales del siglo $V$ a.C. y los comienzos del siguiente. En la sepultura $n^{\circ}$ 176 de la necrópolis de Baza se descubrieron restos de una rueda y de sus radios, fechados en el primer cuarto del siglo IV a.C. Junto al carro aparecieron tres cráteras con el tema del symposion o banquete de sólo varones servidos por una mujer, y en un caso, por una flautista. Se ha pensado que esta iconografía debió tener para el ibero un carácter funerario, como el banquete en las pinturas sepulcrales de Etruria y de la Magna Grecia. Otras tres cráteras van decoradas con escenas dionisíacas, como Ménades danzando furiosamente delante del trípode de Apolo. En una de ellas se representó el templo del dios con su estatua, con Ménades danzando delante de ella. Es muy dudoso que el ibero captara algo del carácter dionisíaco de estos vasos, pues Dionisos está totalmente ausente del arte ibero. En Etruria se ha propuesto que los etruscos no captaban los mitos griegos, ignoraban su significado.

Las sepulturas con carros pertenecían a una élite indígena. Los difuntos serían jefes guerreros. Por lo menos, lo fue el varón enterrado en la tumba $n^{\circ} 176$ de Baza donde se recogieron una falcata, restos de un soliferreum, un escudo, varias puntas de lanza y el mango de un escudo. En la tumba de Toya, de tres cámaras y con gran cantidad de cerámica griega de gran valor, el difunto pertenecía a la élite local más alta.
En la tumba $n^{\circ} 9$ de Baza se hallaron restos que podían ser de carro. Se data esta sepultura a mediados del siglo IV a.C. En un posible túmulo de Casares de La Cañada de los Ojos, se recogieron restos de un carro. Dentro del siglo IV a.C. se encontraron en Alcaçer do Sal restos de un carro del tipo de los encontrados en las necrópolis andaluzas. En la sepultura $n^{\circ} 117$ o $n^{\circ}$ 397 de El Cabecico del Tesoro se depositó una posible rueda. En la necrópolis de Medellín se encontraron restos de un posible carro. Se fecha, posiblemente, en el siglo VI a.C.

En el Cerrón de Illescas (Fernández-Miranda, Olmos, 1986, 69-96) se descubrió un relieve modelado en arcilla decorado con una procesión formada por dos carros con sus aurigas, y una figura de pie entre los carros. Cierra la marcha un grifo alado, que entre los pueblos oretanos tenía un carácter fúnebre (FernándezMiranda, Olmos, 1986, 97-101), como lo prueban el prótomo de grifo alado en una tumba de Castulo (Blázquez, 1992, 422-430) y la cabeza de grifo del heroon de Obulco (Blázquez, 1992, 328; Navarrete, 1992, 139-151. Acaso la grifomaquia también tiene sentido fúnebre).

En el heroon de Obulco se ha recogido también un carro, pero se ignora su posible significado. Debió depositarse con sentido fúnebre, por tratarse de un heroon. Podría ser de parada.

\section{CARRO DE EL CIGARRALEJO}

En una sepultura de la necrópolis de El Cigarralero, la $\mathrm{n}^{\circ} 107$ (Fig. 23), se recogió un carro tallado en piedra de forma paralelepípeda. El carro es de caja oval. Está tirado por dos caballos (vid. supra). Las ruedas son de cuatro radios. Estaba reutilizado en el encachado. Podría ser un exvoto, pero también un carro fúnebre empleado en el transporte del cuerpo del difunto, como parece sugerirlo el hallazgo en una tumba, aunque en ésta se halle como material de construcción. Se fecha en el siglo V a.C. o a comienzos del siguiente. Cabré recordó otros carros ibéricos con carácter fúnebre, como el fragmento de caja funeraria ibérica procedente de Torre de Benzalá, Torredonjimeno (Fernández-Miranda, Olmos, 1986, 113-115).

\section{HEROIZACIÓN ECUESTRE}

Se conocen varias esculturas de jinetes depositadas en tumbas, que podrían aducirse como pruebas de heroización entre las antiguas poblaciones hispanas. 


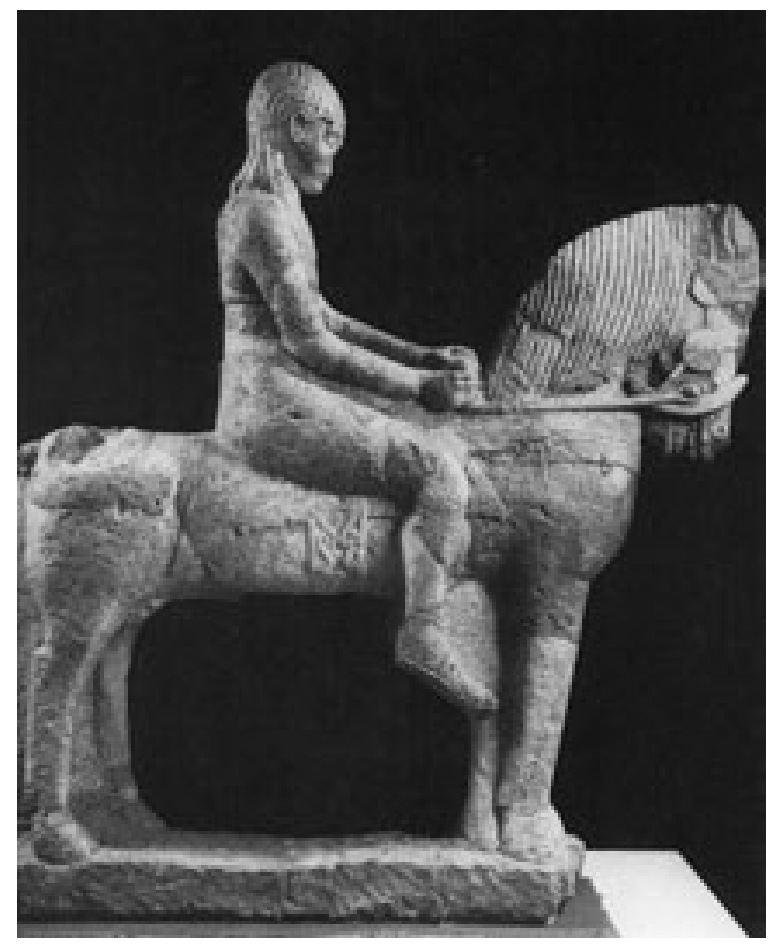

Figura 24: Jinete de la necrópolis de Los Villares (Foto IAA de Madrid).

Dos esculturas de jinetes coronaban dos túmulos en la necrópolis de Los Villares (Albacete) (Fig. 24). Los guerreros vestían al modo de los guerreros de Obulco. Los atalajes del caballo son ricos, al igual que la cincha, que rodea el vientre del animal, que va ricamente adornada. Se fechan en torno al 490 a.C. (Blánquez, 1992, 257, Lám. 3 b-c. Blech, 1998, 446-448, Fig. 186).

\section{DIOS INFERNAL CON CABALLO}

En uno de los relieves del monumento turriforme de Pozo Moro se esculpió un banquete infernal. Un personaje entronizado (Fig. 25) con doble cabeza superpuesta animalesca, que sujeta a un jabalí por una pata, tumbado de espaldas sobre una mesa, sostiene un caldero con un niño en el interior. Delante, otro personaje con cabeza también animalesca, le ofrece un cuenco. Delante del grupo un caballo con cuerpo humano empuña un cuchillo mientras su mano derecha toca la cabeza de otro niño metido en un cuenco. Probablemente se trata de un mito aportado por los fenicios a Occidente. El caballo con cuerpo humano es típico del norte de Siria. Un paralelo se encuentra en el Museo Arqueológico de Ankara. Este caballo sería prueba de la presencia de sirios y arameos en la primitiva colonización fenicia en Occidente, de lo que hay tantos testimonios (Blázquez, 1999,
129-146). La fecha del relieve cae hacia el año 500 a.C. (Blech, 1992, 615-616, Lám. 212 a). Seguramente el caballo en este relieve es un animal infernal que participa en un banquete infernal con sacrificios de niños. El protagonista sería una especie de Kronos fenicio.

\section{VIAJE A LA ULTRATUMBA}

En tres relieves de un cipo de la necrópolis Coimbra del Barranco Ancho, se ve un jinete en marcha perfectamente vestido (Fig. 26). Probablemente se trata de un jinete heroizado en viaje a la ultratumba. En otro relieve, una dama sentada apoya su mano derecha en la cabeza de un niño, escenas muy frecuentes en las estelas áticas del siglo IV a.C., fecha que conviene al cipo de Coimbra del Barranco Ancho (Blázquez, 1992, 452-458. Blech, 2001, Fig. 254, Lám. 227. García Cano, 1997, 266-267, 543-548).

A una pira funeraria de la necrópolis del Estacar de Robarinas se arrojó una placa de pizarra (Fig. 27) que ha llegado en muy mal estado de conservación, sobre la que se grabó un jinete marchando hacia la izquierda. Los arreos del caballo se componen de una piel de pantera que cubre la montura sujeta por dos cintas anudadas. El jinete, que mira al espectador, sujeta una lanza. Esta montura la usaron los aristócratas griegos de época de Alejandro Magno y de tiempos helenísticos como señal de exotismo y de distinción. El jinete viste clámide echada sobre los hombros. La placa podría ser indicio de heroización ecuestre del difunto. En vez de colocar una escultura sobre la tumba, se arrojó a la pira esta pizarra con esta representación (Blanco, 1996, 419-453. Blázquez, 1977, 374-376, Fig.

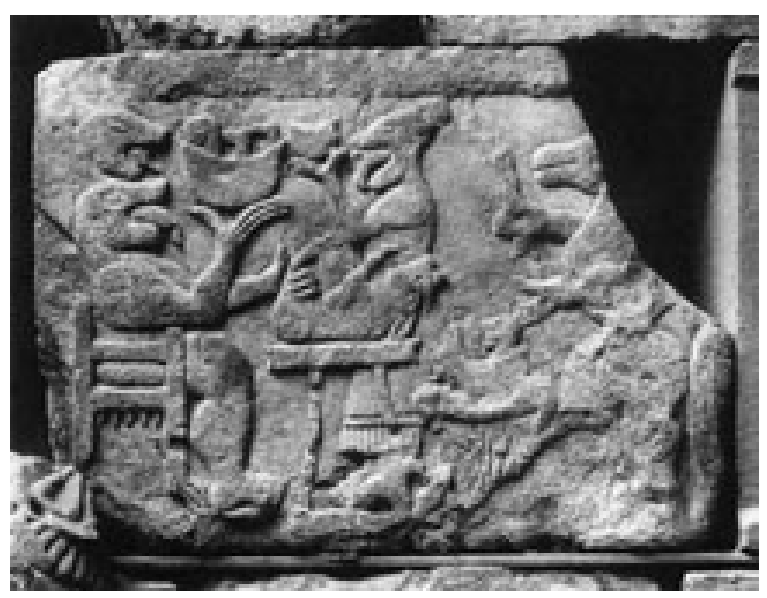

Figura 25: Relieve del monumento funerario de Pozo Moro (Foto IAA de Madrid) 


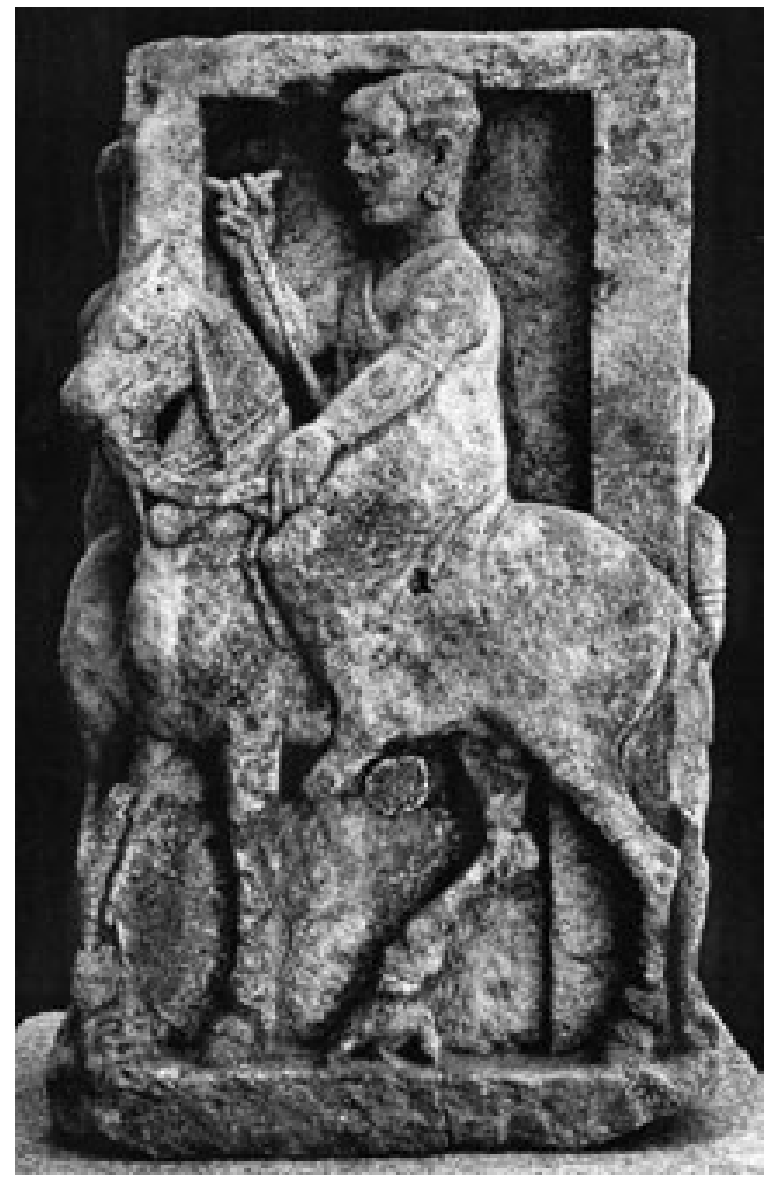

Figura 26: Monumento funerario cuadrado de Coimbra del Barranco Ancho (Foto IAA de Madrid).

163, Láms. XLVIII-L, 1). Se conocen paralelos a este jinete en la Magna Grecia, igualmente, se heroizaban los difuntos. En cráteras de volutas del Pintor de Copenhague 4223, se representa al difunto una vez con lanza y caballo recibiendo honores fúnebres, datadas entre los años 310330 a.C. (Pugliese Carratelli, 1990, 216-217, Figs. 318-320). Estas pinturas demuestran la he-

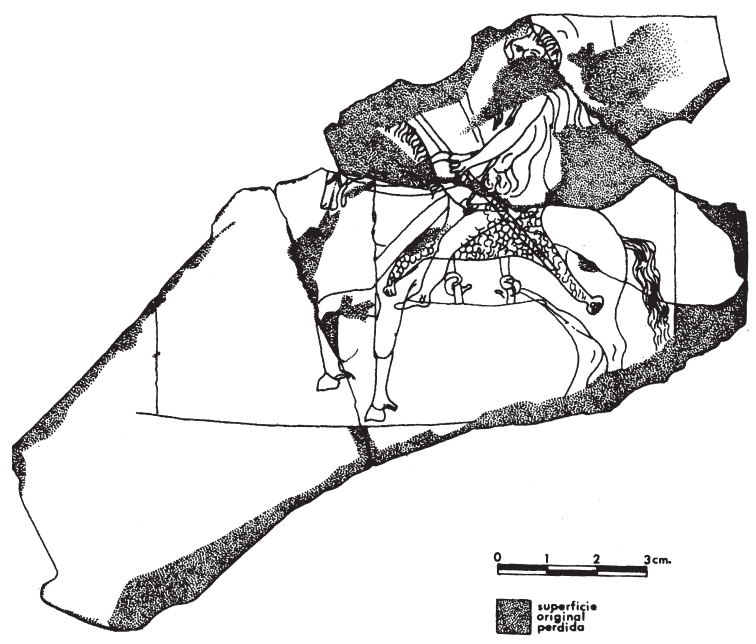

Figura 27: Placa de pizarra con jinete, necrópolis del Estacar de Robarinas (Dibujo F.J. Sánchez-Palencia).

roización de los varones en la Magna Grecia, y que recibían honores fúnebres.

En un relieve rectangular se representa un caballo marchando hacia la izquierda, hacia Lasa (Pfiffig, 1975, 327-330), con las alas extendidas y a un árbol entre ambas figuras. La presencia de Lasa, diosa etrusca vinculada con la muerte, refuerza el carácter fúnebre del caballo. Lasa presencia el sacrificio de los troyanos en honor de Patroclo en la mencionada tumba François y la lucha fratricida entre Eteocles y Polinices, en una urna de Sarteano, Chiusi, fechada en el siglo III a.C. (Bianchi Bandinelli, Giuliano, 1973, 306, Fig. 355). Estas escenas refuerzan el carácter de la diosa etrusca y del caballo.

En el citado kalathos de Elche de la Sierra, y como ya indicamos, parece que pudo pintarse el tránsito al Más Allá, o algún rito trascendente desconocido, relacionado con el mismo (Fig. 28).

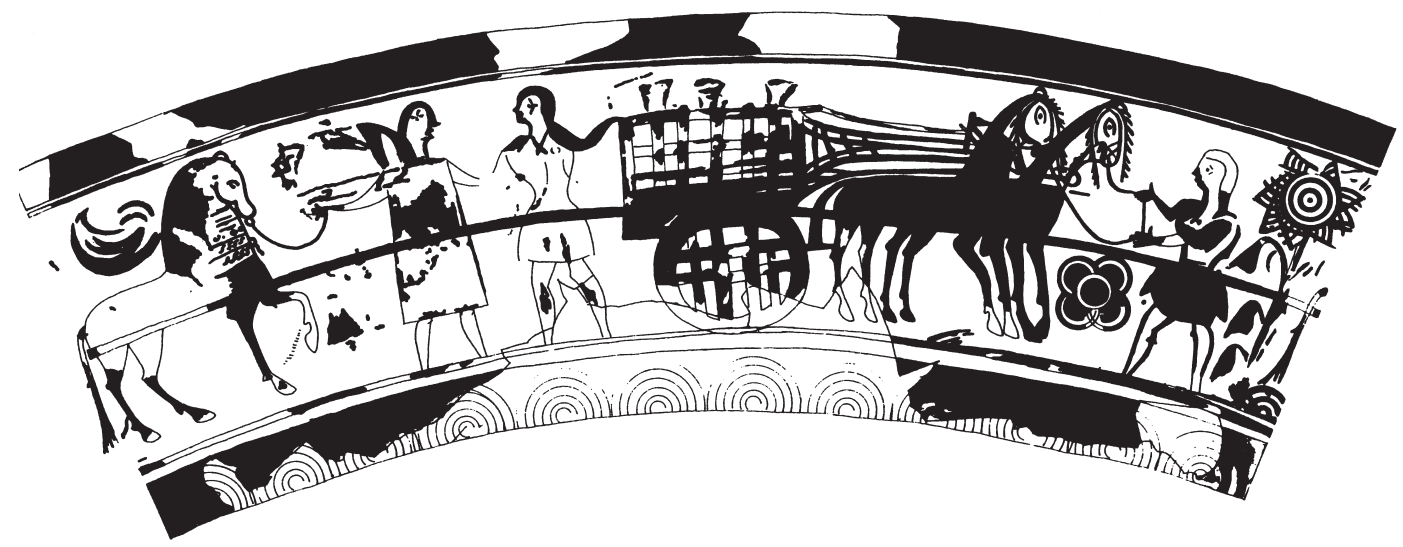

Figura 28: Desarrollo de la decoración de un kalathos de Elche de la Sierra, según J.J. Eiroa (Foto F. Quesada,1997, 163). 


\section{RITUALES FÚNEBRES CON CABALLOS}

En los rituales fúnebres que se celebraban el día del entierro de los régulos o de las élites de poder o/y de riqueza, participaban caballos.

En los funerales representados en el heroon de Obulco, aparte de luchas de soldados equivalentes a los combates de gladiadores que se celebraban en Etruria (tumbas de los Augures de las Olimpiadas, de Pulcinella; Steinbräger, 1984, 289), y en Paestum, en el siglo IV a.C. (Pontrandolfo, Rouveret, 1992, 109-111, 135-137, 145, 149, 151,158), participan jinetes (Fig. 29) a pie, armados (Navarrete, 1987, 47-52. Blanco, 1996, 552. Blázquez, 1992, 406). Son los mismos rituales celebrados en los funerales de Viriato en el año 139 a.C., Apiano (Iber. LXXI) escribe: "El cadáver de Viriato, magníficamente vestido, fue quemado en una altísima pira; se inmolaron muchas víctimas, mientras que los soldados, tanto los de a pie como los de a caballo corrían alrededor con sus armas y cantando sus glorias al modo bárbaro, y no se apartaron de allí hasta que el fuego fue extinguido. Terminado el funeral, celebraron combates singulares sobre su túmuIo". Y Diodoro (XXXIII, 21): "El cadáver de Viriato fue honrado magníficamente y con espléndidos funerales. Hicieron combatir ante su túmulo 200 parejas, honrando así su eximia fortaleza".

Los funerales de Viriato son, muy probablemente, un ritual indígena, no importado de Roma. Son una decursio, rito fúnebre muy antiguo, que consistía en dar tres vueltas a la pira donde se quemaba el cadáver, o al túmulo, jinetes, a lo que seguían carreras, desfiles y combates de jinetes (Blázquez, 1999, 101-117, 341-362). Este ritual está representado en la base de la Columna de Antonino Pío, hoy en el Cortile Della Pigna, en el Vaticano (Bianchi Bandinelli, 1970, 288, Fig. 322). En el sureste ibérico se celebraba una danza guerrera fúnebre con máscaras (Blázquez, 1983, 265-268, Fig. 138; 2001-2002, 171-172).

En Urso (Osuna, Sevilla) se levantó en el siglo III a.C. un heroon, en el que quedaron bien reflejados los rituales en los que participan damas aulistas, oferentes, soldados, acróbatas, luchas de fieras y un jinete al galope armado con falcata, que harían, probablemente, circunvalaciones a la pira (Blech, 1985, 627-628, Lám. 226 b. García y Bellido, 1971, Fig. 70).

Llama la atención que en los rituales fúnebres que celebraban las poblaciones iberas no hay rastro de carreras de carros, tan frecuentes en las honras fúnebres de Etruria: Tumbas delle Colle Cassucinni, del segundo cuarto del siglo $\mathrm{V}$ a.C; de Poggio al Moro, de la misma fecha; de la

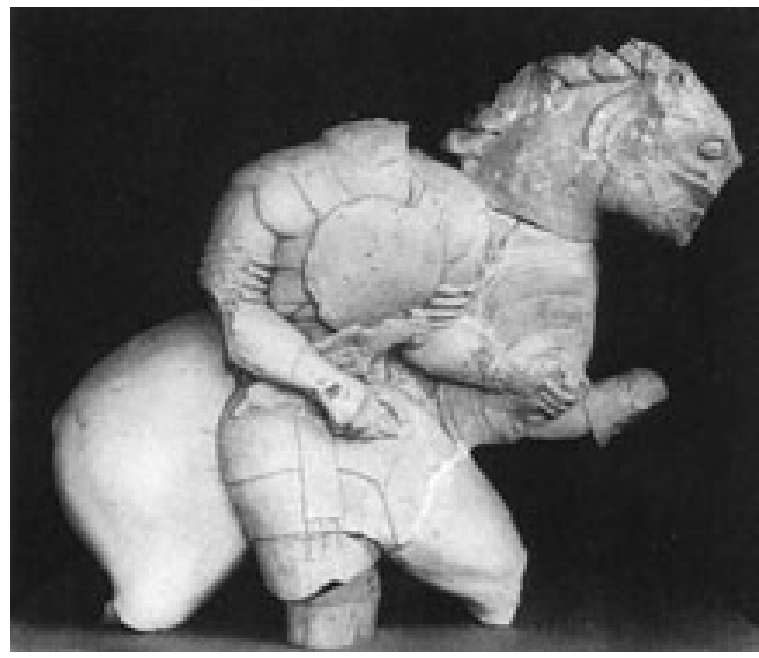

Figura 29: Jinete del heroon de Obulco (Foto IAA de Madrid).

Scimmia, en torno al 480-470 a.C.; de las bigas, hacia el 490 a.C.; del Orco, del tercer cuarto del siglo IV a.C. (Steingräber, 1984, 272, Lám. 189; 274, Láms. 191-192; 279, Láms. 189-192; 295297; 334); en tumbas de Paestum (Pontrandolfo, Rouverete, 1992, 102-103, 109, 111, 128, 137 , 139, 144, 156-157, 160-161, 188-189, 196-197, 202, 208, 210-211, 216-217, 231, 251, 256, 262262, 279-280, 284-285. Bronsosn, 1965, 89-106; y en tumbas tracias, Kazanlak.

Estos testimonios arqueológicos probarían que, entre las poblaciones iberas (Aranegui, 1997) se daría la heroización ecuestre de los jefes y de las élites aristocráticas. Estas élites aristocráticas ibéricas utilizaban el caballo. No se puede hablar de monarquías divinas, ni de divinización de los personajes (Almagro, 1996), concepto que no existe entre las poblaciones prerromanas de lberia (Blázquez, 2006, 145-164). Ninguna fuente menciona reyes divinizados entre las poblaciones hispanas (Caro Baroja, 1971, 77-159). Este concepto no existió ni en Etruria (Morigi, 2001), ni en Roma (Cristofani, 1990. Martínez Pinna, 1996, 1999), Rómulo, fundador de Roma, fue asimilado tardíamente a Quirino, pero debió ser una especie de apoteosis semejante a la de los emperadores romanos, ni en Grecia (Nilson, 1961, 135-180), ni en Israel ni en otros pueblos limítrofes, como filisteos, amonitas y edomitas. Tan sólo en Ugarit se menciona a los 50 reyes divinizados (Olmo Lete, 1992, passim. Xella, 2002, 281-297). En Mesopotamia, entre otros monarcas, en la dinastía acadia fue divinizado en vida Narâm-Sin (2291-2255), hecho hasta entonces no conocido en el país; Shulgi (ca. 2095-2048 a.C.), segundo rey de la III dinastía de Ur; y Hammurabi sex- 


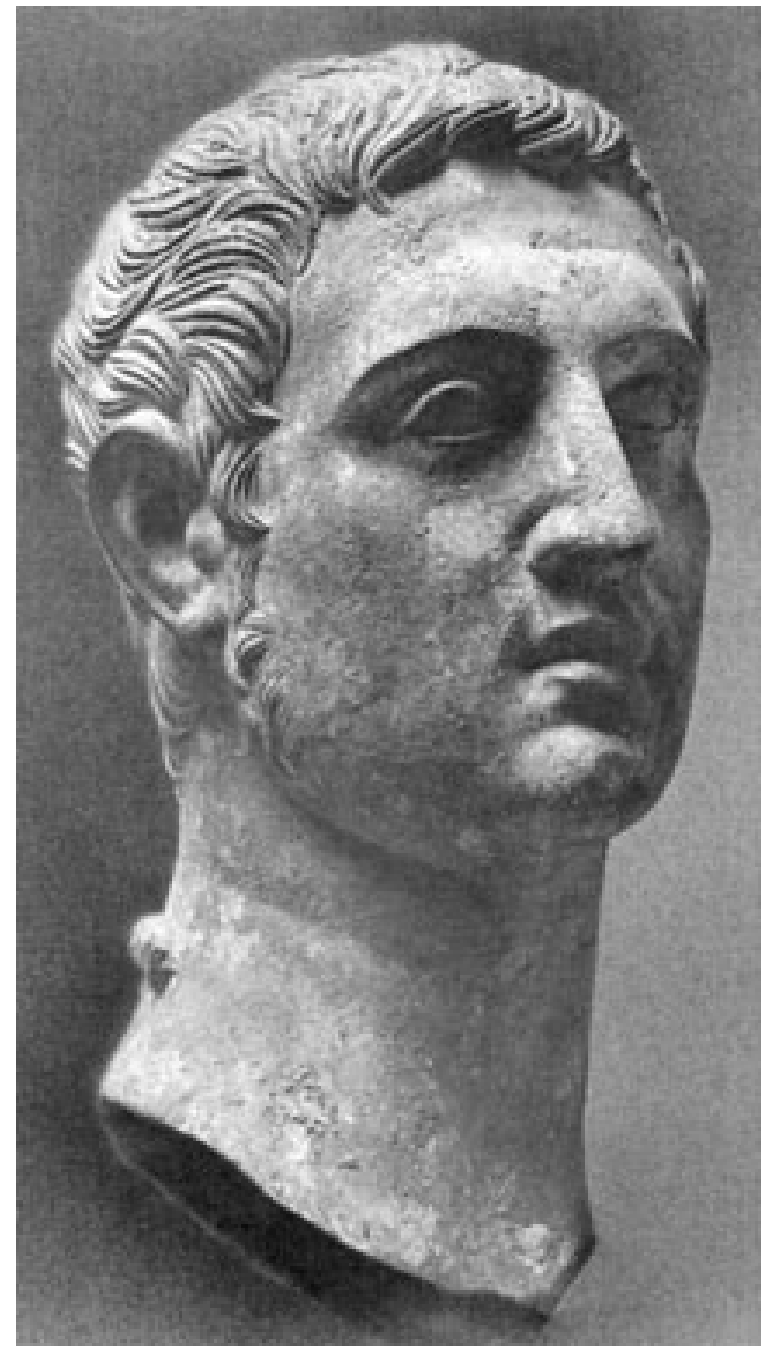

Figura 30: Cabeza de personaje heroizado, Azaila (Foto M. Beltrán)

to rey de la dinastía paleobabilónica (ca. 17921550 a.C.) (Padró, 1983, 60-75).

La divinización de los monarcas en Grecia empieza poco antes de Alejandro Magno, que se divinizó en vida (Blázquez, 2006, 265-272), proclamándose hijo de Zeus. Algunos diádocos se divinizaron en vida, como Antígono Gonatas (ca. 301-282 a.C.) y su hijo Demetrio Poliorcetes (336-283 a.C.), que lo fueron por los aduladores atenienses, que les aclamaron dioses salvadores; crearon anualmente un sacerdocio para los dioses salvadores; el nombre de éste era el que había de servir para fijar la fecha de todos los decretos y escrituras, en vez de el del arconte. Decretaron que en el gran peplo de Atenea Parthenos, la diosa protectora de Atenas, se colocaran sus retratos con los de los dioses, y consagrando el lugar donde desembarcaron, erigieron un altar que habría de llamarse de Demetrio Cetebata; añadieron a las tribus otras dos, la Demetriade y la Antigonide; el consejo, que antes era de 500 miembros, lo hicieron de 600 por participar 50 de cada tribu. Un adulador descarado propuso que se recibiera a Demetrio, cuantas veces fuera a Atenas, con las mismas ceremonias que a Ceres y a Baco, y al que se aventajara en brillantez y esplendor en este recibimiento, se le diera dinero del Erario público para una ofrenda. Finalmente, que al mes muniquion se le llamara demetrion; el último día del mismo mes, demitridi, y que a las fiestas llamadas Bacanales se les mudara el nombre por el de Demetrias. La adulación desvergonzada continuó:"Además de estos se le decretó todavía otro honor más desmedido y disonante, escrito por Dromoclides Esfecio, sobre que para la consagración de los escudos en Delfos se tomara oráculo de Demetrio; pero será mejor copiar el tenor del decreto, que es como sigue: "A la buena hora: Le ha parecido al pueblo nombrar un ciudadano de Atenas que, constituyéndose cerca del Salvador, y haciendo las debidas libaciones, pregunte a Demetrio Salvador cómo con más piedad, con más decoro y con mayor prontitud ha de hacer el pueblo la dedicación de las ofrendas, y que lo que respondiere aquello haga el pueblo". Con tales desatinos embaucaron a un hombre que ya de suyo no era de los más cuerdos" (Traducción de A. Sanz Romanillos).

Todo esto lo cuenta Plutarco en La vida de Demetrio Poliorcetes (X-XIII). Todos estos honores divinos explicaron la divinización de $\mathrm{Q}$. Cecilio Metelo en Córdoba.

En Hispania, el primer personaje que recibió honores divinos fue Q. Cecilio Metelo, el general romano que luchó contra Sertorio en el invierno del 74-73 a.C. en Córdoba. Fue acogido por grandes multitudes, escribe el gran historiador amigo de César, Salustio (Hist. II, 70). Adornaron la casa con tapicerías y estatuas, erigiéndose tablados para representaciones histriónicas, esparciendo de azafrán la tierra y otras cosas, al modo de los más famosos templos. Estando el general sentado, aparecía bajando por un cable una estatua de Victoria, con su artificioso estrépito de truenos, y depositaba una corona sobre la cabeza, se le hacían plegarias, como si un dios hubiera aparecido.

Todos estos honores divinos explican la escena del templo de la acrópolis de Azaila. En el mismo muy probablemente una Victoria coronaba a un caudillo hispano junto a un caballo (Fig. 30). La presencia de un toro, animal de claro sentido funerario (Blázquez, 1983, 247, Figs. 125-126; 2001, 245-289. López Monteagudo, 1989. Blech, 1993, 572, Lám. 132 a), refuerza el carácter fúnebre del grupo. Delante se encontra- 
ba un altar (Beltrán, M., 1996, 156, 159. Blech, 1993, 90-91, Fig. 39 Láms. 38, 120). La cerámica campaniense no parece que es en Azaila posterior a mediados del siglo I a.C. (Beltrán, 1979, 141-232). Acertadamente, M. Beltrán halló los prototipos para el grupo en las gemas en las que figura Cn. Pompeyo Magno junto a un caballo, con corona, o en los áureos del siglo I a.C., en los que una Victoria corona a Sila sobre una cuadriga. Para esa fecha, no puede ser un retrato de Augusto joven la cabeza masculina hallada en el templo.

Plutarco (Sert. XXII), escribe que las ciudades por donde pasaba le recibían con sacrificios y altares. Dice que aceptó que le coronaran y le ofrecieran suntuosos banquetes, en los que brindaba adornado con ropas triunfales, y se tenían distintas Victorias con tal artificio que, por medio de un mecanismo, le presentaban trofeos y coronas de oro; y coros de mozos y de mujeres le cantaban himnos de victoria. Aunque R. Etienne y nosotros defendimos que estos honores eran propuestos por las poblaciones indígenas, hoy creemos que lo fueron por los romanos, pues Salustio puntualiza que fue el cuestor Cayo Urbino y otros los que plantearon estos honores. Por estos años, en Oriente, los generales romanos recibían honores divinos. A Lisandro, el general espartano que venció a los atenienses definitivamente en el año 404 a.C. en la Guerra del Peloponeso, las ciudades de Grecia le ofrecieron altares como a un dios, y le ofrecían sacrificios. Fue, asimismo, el primero en cuyo honor se cantaron peanes.Los samios decretaron que las fiestas llamadas entre ellos Junonias, en adelante se llamaran Lisandrias (Plu., Lis. XVIII).

\section{LA HEROIZACIÓN ECUESTRE ENTRE LAS POBLACIONES INDOEUROPEAS HISPANAS}

La heroización ecuestre no sólo se documenta entre las poblaciones prerromanas del sur de Hispania, sino entre los pueblos indoeuropeos, como los celtíberos (Barril, Quesada, 2005). En diferentes regiones de la Hispania prerromana, los caballeros eran muy numerosos (Str., III, 4, 15) (Almagro-Gorbea, 2001. Capalvo, 1996. Jimeno, 2005. Lorrio, 1997), y la caballería desempeñaba un papel importante (Blázquez, 1957, 162-190. Guadán, 1979). No es extraño pues que la heroización ecuestre se documente entre estos pueblos (Str. III, 4, 5).

En una tumba de San Antonio de Calaceite (Teruel) se depositó un caballo entre dos discos de carácter solar (Blázquez, 1977, 252-258). Es muy probable que haya que atribuir a este bronce el mismo carácter fúnebre que a los pequeños caballos de terracota depositados en una tumba de Ampurias, es decir, un carácter funerario. La tumba podía ser de la época de La Tène.

En Aguilar de Anguita (Guadalajara) han aparecido dos estelas decoradas con un jinete, fechadas en el siglo IV a.C. El grupo tendría el mismo carácter que los prótomos de caballo del santuario de Roquepertuse, fechado en los siglos III-II a.C., que según F. Benoit sería el documento más antiguo de la heroización de los difuntos (Varagnac, Fabre, 1956, 94, Fig. 13). En dos estelas halladas en San Antonio de Calaceite (Fig. 31), y una tercera encontrada en Palermo, Caspe, se representa un jinete con escudo oval acompañado de lanzas hincadas (Blázquez, 1963, 408, Figs. 1-2), que se ha fechado en el primer tercio del siglo I a.C., pero que podría fecharse dos

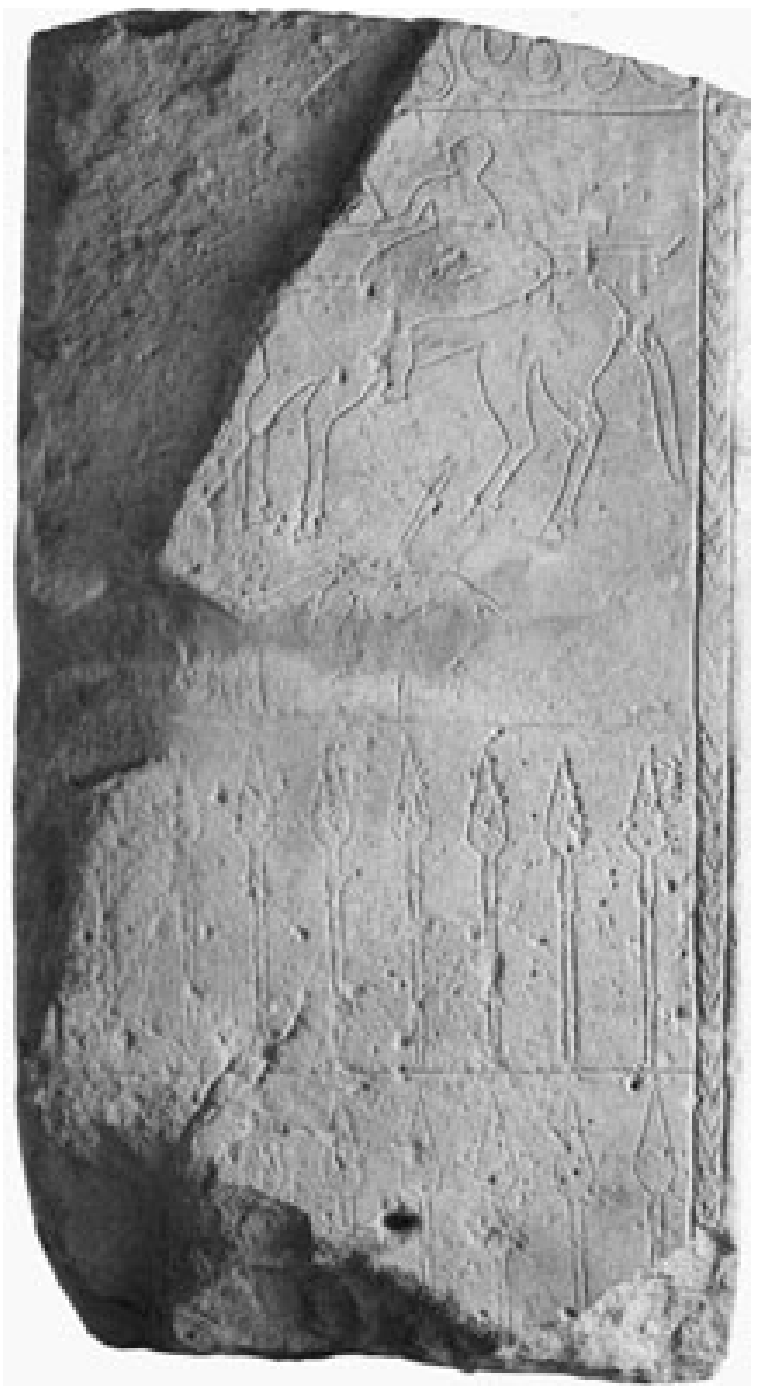

Figura. 31: Estela de Calaceite, con jinete y lanzas (Foto M. Beltrán). 

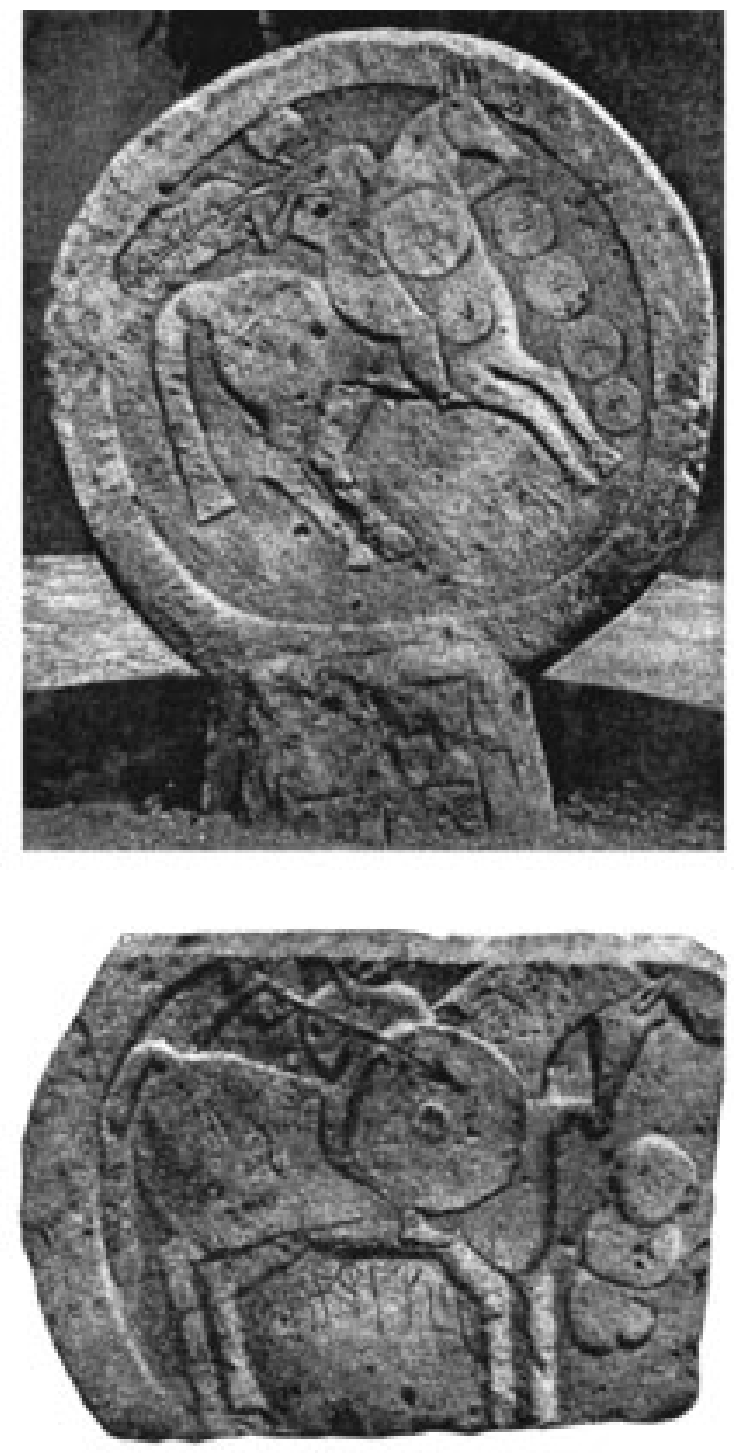

Figura 32: Estelas perdidas de Clunia (Foto A. García y Bellido).

siglos antes. Aristóteles, el maestro de Alejandro Magno, recoge la noticia (Pol. 1324 b) de que clavaban los guerreros iberos en su tumba el mismo número de lanzas que los enemigos muertos en combate (Beltrán, 1996, 176, Figs. 170-171). En las estelas del Bajo Aragón son frecuentes las estelas con lanzas hincadas. Estas estelas son la confirmación de esta costumbre entre los celtíberos. En estas estelas el jinete estaba heroizado. En la estela de La Tallada, en Chipiona, se grafiteó un carro de guerra tirado por un caballo.

En Clunia (Burgos) (Fig. 32) se encontraron cuatro estelas con el mismo tema, pero sólo dos se han conservado hasta la última Guerra Civil española, cuando desaparecieron. Representan a un jinete rodeado de caetrae (Blázquez, 1963, 412-413, Figs. 8-9. García y Bellido, 1949,
371-372, Figs. 367-368). En una estela, el jinete lleva al hombro tres caetrae colgadas de una pértiga. Delante del caballo hay otras cuatro, y sobre los cuartos delanteros del caballo otras dos, una de mayor tamaño. En la primera estela, los escudos colocados delante del caballo son tres. El que embraza el jinete, que también sostiene una lanza, es de mayor tamaño. Una estela lleva una inscripción ibérica (Untermann, 1985, 5, 94, lám. 174 b). Estos jinetes celtíberos serían equivalentes al jinete campano ante crátera, pintado en la tumba $n^{\circ} 58$ de Andriuolo (Portrandolfo, Rouveret, 1992, 153. Pugliese Carratelli, 1990, 331, Fig. 505) y a otros jinetes parecidos, todos fechados en el siglo IV a.C. El número de escudos alude al número de enemigos matados en combate. Otras estelas pertenecen a este grupo, como la de Lougesterico, hoy en el Museo de Burgos (Blázquez, 1963, 414, fig. 14. García y Bellido, 1949, 375, Fig. 375) con antropónimo -Segius(Albertos, 1966, 202) y patronímicos -Aius, Caeno- (Albertos, 1965, 12) indoeuropeos. El jinete lleva a hombros una pértiga con tres escudos. El antropónimo del jinete está compuesto sobre el teónimo Lug-, el gran dios de los pueblos celtas, muy venerado en Hispania (Blázquez, 1962, 9093; 1975, 117-119; 1983, 224, 283-284. Marco, 1994, 329-332). En tres estelas fragmentadas y en otra cuarta, procedentes de Lara de los Infantes (Burgos), se representa un jinete con lanza y en un caso, con ancho escudo oval (Fig. 33). Las
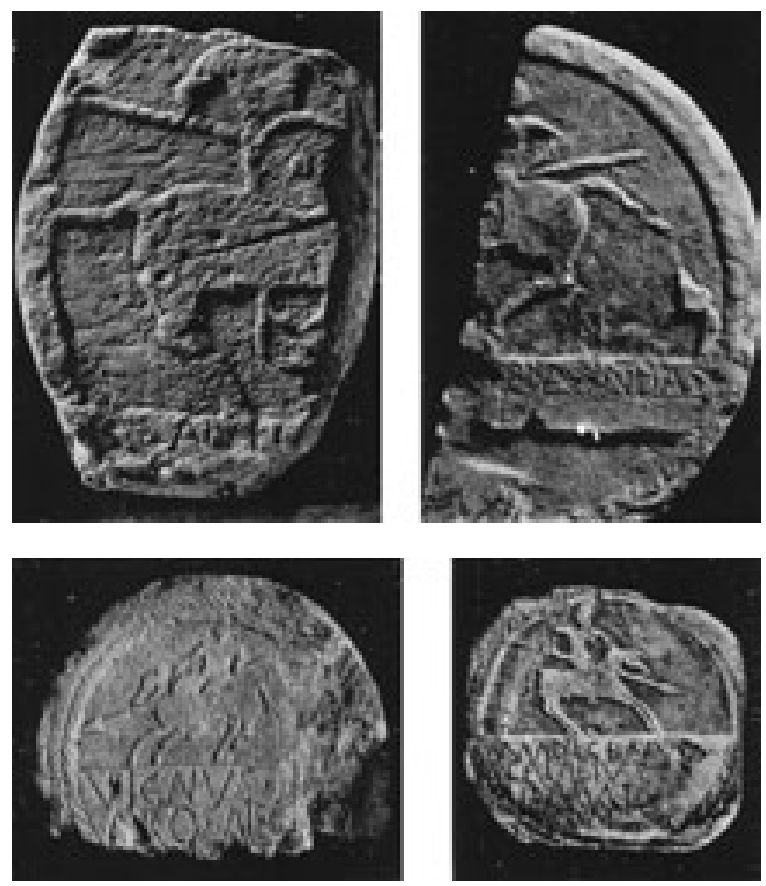

Figura 33: Estelas de Lara de los Infantes con jinetes heroizados (Foto A. García y Bellido). 


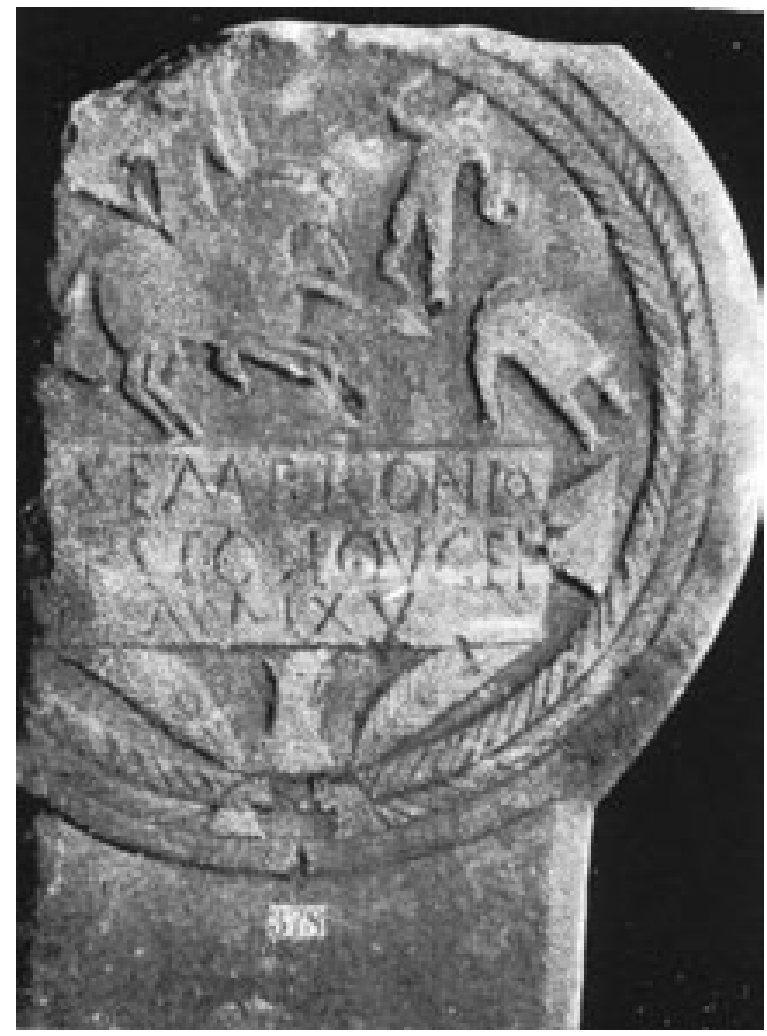

Figura. 34: Estela con escena de caza, altar, palmas y prótomos de caballos de Lara de los Infantes (Foto A. García y Bellido).

cuatro son ya de época romana, pues llevan debajo letras latinas. Los antropónimos Maducenus y Cosegius (Albertos, 1966, 142, 98) y el patronímico Ambatus (Albertos, 1966, 20-21) son indígenas. En las cuatro, el jinete sostiene una larga lanza (Blázquez, 1963, 414, Figs. 6-7. García y Bellido, 1949, 372-375, Figs. 369-372. Abásolo, 1978, 90, Lám.LI.2; 91-92, Lám. LII.2; 95-96, Lám. LV.1). El tema del jinete marchando se repite en tres lápidas de la provincia de Soria (Jimeno, 1980, 67-69, Láms. XVI-XVIII.1) y en una de Santander (Blázquez, 1983, 272, Fig. 167). Una estela de Lara de los Infantes (García y Bellido, 1949, 370, Fig. 365. Abásolo, 1974, 92, Lám. LII), con patronímico -Lougei- indígena (Albertos, $1966,137)$, es importante para el contenido del presente trabajo. Un jinete alancea a un jabalí (Fig. 34) ayudado por un ¿esclavo? defendido por una caetra. Debajo de la inscripción, sobre una tábula, se coloca un altar entre dos palmas de victoria, y debajo dos prótomos de caballos enfrentados que refuerzan el carácter funerario del tema de la caza, que data de muy antiguo en Grecia. Baste recordar el llamado sarcófago de Alejandro Magno, con una escena de caza del león, obra realizada entre los años 325-311 a.C.
El sarcófago se halló en la última de las siete cámaras sepulcrales de la necrópolis real de Sidón. Posiblemente recibió el cuerpo de Abdalónimo, último rey de Sidón, instaurado en su trono por Alejandro después de la batalla de Isos, 333 a.C, y que gobernó hasta su muerte, acaecida en 311 a.C. (Pollitt, 1989, 80-82, Figs. 42-43).

Un segundo ejemplo que cabe recordar, es un sarcófago chipriota de la antigua colección Cesnola, hoy en el Metropolitan Museum of Arts de Nueva York, datado en el segundo cuarto del siglo $\mathrm{V}$ a.C, con cacerías de toro y de jabalí (Karageorghis, 2000, 204-205, Fig. 331). En otra estela también procedente de Lara de los Infantes se representó un jinete con lanza sobre unos arcos, a los que se les ha atribuido frecuentemente un carácter fúnebre de puertas de Hades, pero que Abascal sugiere que aluden al monumento fúnebre (García y Bellido, 1949, 369, Fig. 364).

En una urna etrusca de Sarteano, Chiusi, hoy en el Museo Arqueológico de Arezzo, fechado a finales del siglo II a.C. o a comienzos del siguiente, la difunta está sentada entre dos prótomos de caballos a los que abraza (Bianchi Bandinelli, Giuliano, 1973, 325, Fig. 376). Esta

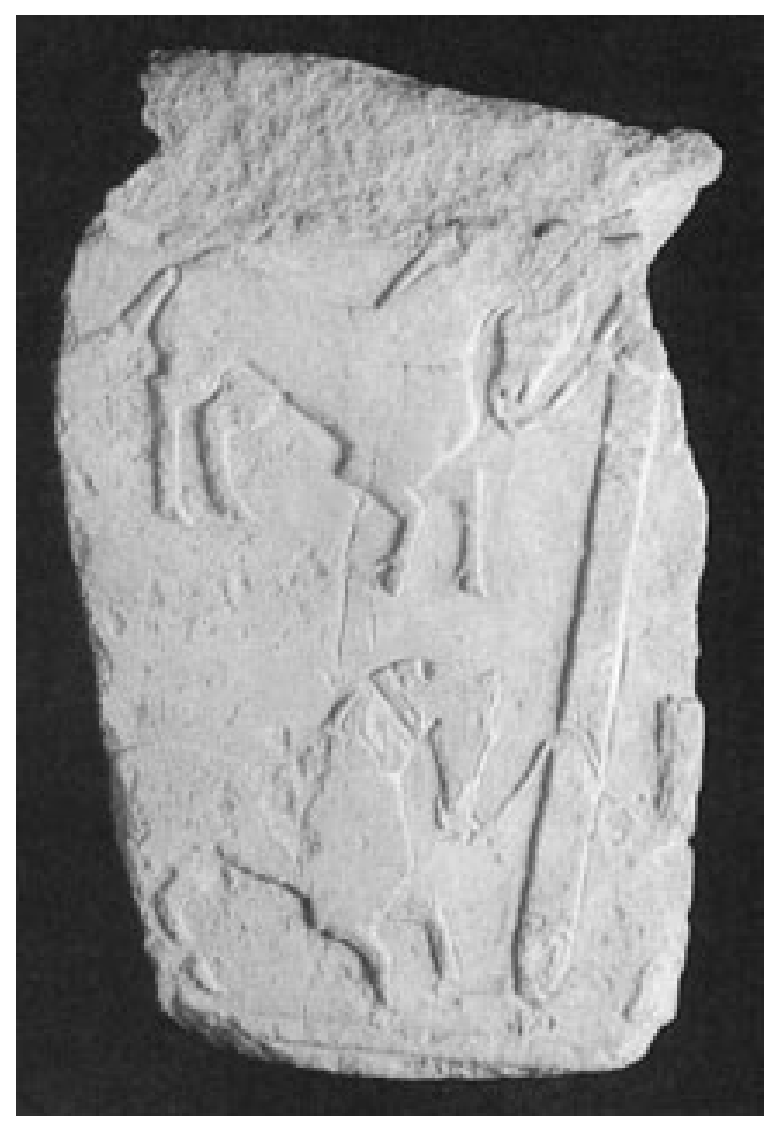

Figura 35: Monumento funerario de Vispesa, Tamarite de Litera (Foto M. Beltrán). 
urna prueba que los prótomos de caballos en estelas o urnas no son privativos de los pueblos de Hispania.

De gran novedad es la escena representada en la estela de Alcubilla de Avellaneda (Soria). Ante una dama sentada se encuentra un jinete, quizás despidiéndose, para partir al Más Allá (Blázquez, 1963, 420, Fig. 19).

\section{HEROIZACIÓN EN SUESETANIA}

En Suesetania también se documenta la heroización ecuestre en las estelas. Del monumento funerario de Vispesa (Tamarite de Litera), se conserva un fragmento de relieve del más alto interés. Tres caballos están atados a un poste (Fig. 35). Este testimonio no es único. En un fragmento de pilar-estela hallado en El Acampador (Caspe), un jinete lleva una larga lanza. En la estela de El Palao (Alcañíz, Teruel) (Fig. 36) la escena es mucho más completa. El jinete levanta una lanza y presenta una caetra. El campo lo ocupan una gran mano abierta, un enemigo caído, con caetra, es decir, matado por el jinete, un perro que, sin duda, acompañaba al amo de los combatientes, y buitres, que acuden a devorar los cadáveres de los soldados muertos. La costumbre de cortar las manos de los enemigos estaba muy extendida entre las poblaciones de la Hispania Antigua. Estrabón (III, 3, 6) la considera típica de los lusitanos, y Diodoro Sículo, propia de de los iberos en general. Esta costumbre bárbara fue, imitada por los romanos en el cerco de Numancia (App., Iber. LXIX, 93), cuando Escipión cortó las manos a 400 jóvenes partidarios de continuar la guerra apoyando al caudillo numantino Retogenes. M. Beltrán (1996, 178-181, Figs. 172-173, 175) con

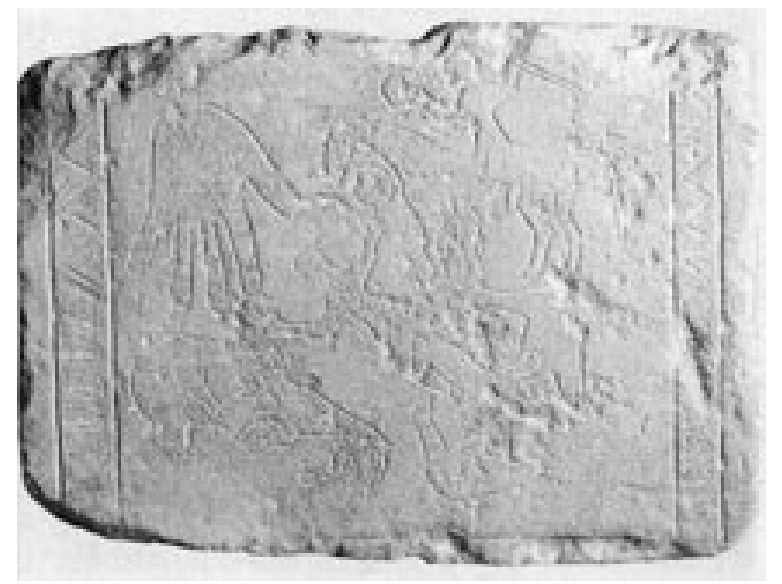

Figura 36: Estela de Palao, Alcañiz, con jinete, enemigo caído, mano cortada, buitres y perro (Foto M. Beltrán). ocasión de publicar estas estelas acertadamente, escribe: "El caballo es un animal que simboliza la heroización, la inmortalidad y la apoteosis del difunto. Junto a él, los astros manifiestan la unión de los ritos funerario y solar. El caballo es el portador del alma del difunto hasta su última morada. El denominado Bronce de Calaceite, en el que se asocian el caballo y los discos solares, constituye uno de los mejores ejemplos de la unión de dichos ritos".

La concepción astral de la ultratumba entre muchas poblaciones de la Hispania Antigua queda bien patente en los signos astrales, sol, luna y estrellas, que coronan las estelas, y también en dejar que los cadáveres de los guerreros muertos se los coman los buitres (Blázquez, 1962, 12-14; 1975, 182-189. 1993, 265-266. Sopeña, 1995, 189-209. Marco, 1994, 281-283).

\section{LA HEROIZACIÓN ECUESTRE ENTRE LOS PUEBLOS DEL NORTE DE HISPANIA}

Entre las poblaciones hispanas del norte de Hispania, igualmente se conocen algunos testimonios de heroización ecuestre. Baste recordar la estela de Iruña, con jinete con lanza grafiteado en la piedra (Blázquez, 1963, 414, Fig. 14); la estela de Oyarzun, hoy conservada en el Museo de San Telmo de San Sebastián, con jinete en la cabecera del monumento (Blázquez, 1963, 416, Fig. 12), o la estela de Lerga, de la que se han perdido las cabezas del jinete y del caballo. Se trata de una escultura, pues el caballo se encuentra sobre un pedestal. La estela tiene tres registros. El superior está ocupado por el caballo. El central, por dos figuras humanas de pie, una de las cuales -la de la derecha- sostiene una lanza y levanta un objeto rectangular, que podía ser un vaso. Entre los dos registros se halla una inscripción y una segunda de tres líneas en la parte inferior. Las inscripciones son importantes para el estudio de la lengua protovasca. La estela se fecha entre los siglos II y III (Blázquez, 1963, 418, Fig. 13). En esta época, los vascos ocuparon la Navarra media con una extensión por Cinco Villas (Beltrán, 2001, 61-68).

\section{CABALLO Y CABEZAS CORTADAS}

En la Meseta son frecuentes los hallazgos de fíbulas que representan a un caballo con una cabeza debajo del hocico. Aluden al rito bien conocido en Galia (Almagro-Gorbea, Torres, 1999). Diodoro $(\mathrm{V}, 29,4)$ al hablar de los celtas mencio- 
na la conservación de las cabezas como trofeos. Este texto está confirmado por la afirmación de Estrabón (IV, 4-5). Al salir al combate cuelgan del cuello de sus caballos las cabezas de los enemigos muertos y las llevan consigo para fijarlas como espectáculo en los vestíbulos. Las cabezas de las personas importantes, las enseñan a los extranjeros conservadas en aceite de cedro, y rehúsan venderlas, aún a precio de oro. El Geógrafo añade que esta costumbre la tenían la mayoría de los pueblos del norte. El historiador romano, Livio, también contemporáneo de Augusto, al relatar la batalla de Sentinum, 215 a.C., escribe: "Los jinetes galos Ilevaban las cabezas colgadas de los pechos de los caballos y clavadas en las picas, cantando canciones según sus costumbre". El mismo autor (Liv. XXIII, 24), refiere de los Boios, al escribir sobre el año 216 a.C.: "Los Boios, entre aclamaciones, Ilevaron los despojos del cuerpo y la cabeza cortada de su jefe al templo, que ellos consideran el lugar más sagrado. Pulido después el cráneo, según su costumbre, adornaron la calavera con oro, pues era para ellos un vaso sagrado para usarlo en las libaciones durante las solemnidades, al mismo tiempo que una copa para los sacerdotes y para los guardianes del templo". Tácito (Ann. I, 61), al describir la llegada de Germánico a Teotoburgo, donde se encontraban los restos del ejército de Varo, cuenta que yacían trozos de lanzas y miembros de caballos al mismo tiempo que las cabezas colgadas de los árboles. En

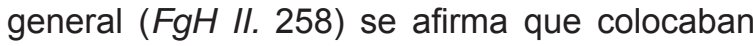
las cabezas de los enemigos en los propileos. Estas fuentes no se refieren a la heroización de los jinetes. Se recuerdan por vincular al caballo con los muertos. Esta bárbara costumbre tiene precedentes en la narración de Diodoro (XIII, 57, 3) referente a la actuación de los cartagineses en la toma de Selinunte, año 409 a.C., durante la Segunda Guerra Greco-Púnica. Mutilaban las extremidades de los cadáveres. Algunos llevaban racimos de manos cortadas colgadas de la cintura y otros blandían las cabezas cortadas clavadas en las puntas de las lanzas.

En la Guerra Dácica, todavía está documentada la costumbre de cortar las cabezas a los enemigos en la Columna Trajana (Lepper, Frere, 1988, 109-111, Lám. LI).

\section{HEROIZACIÓN DE LOS PRÍNCIPES INDÍGENAS: LA DIADEMA DE MONES}

F. Marco, uno de los mejores conocedores de la religión indígena en la Hispania Antigua, ha

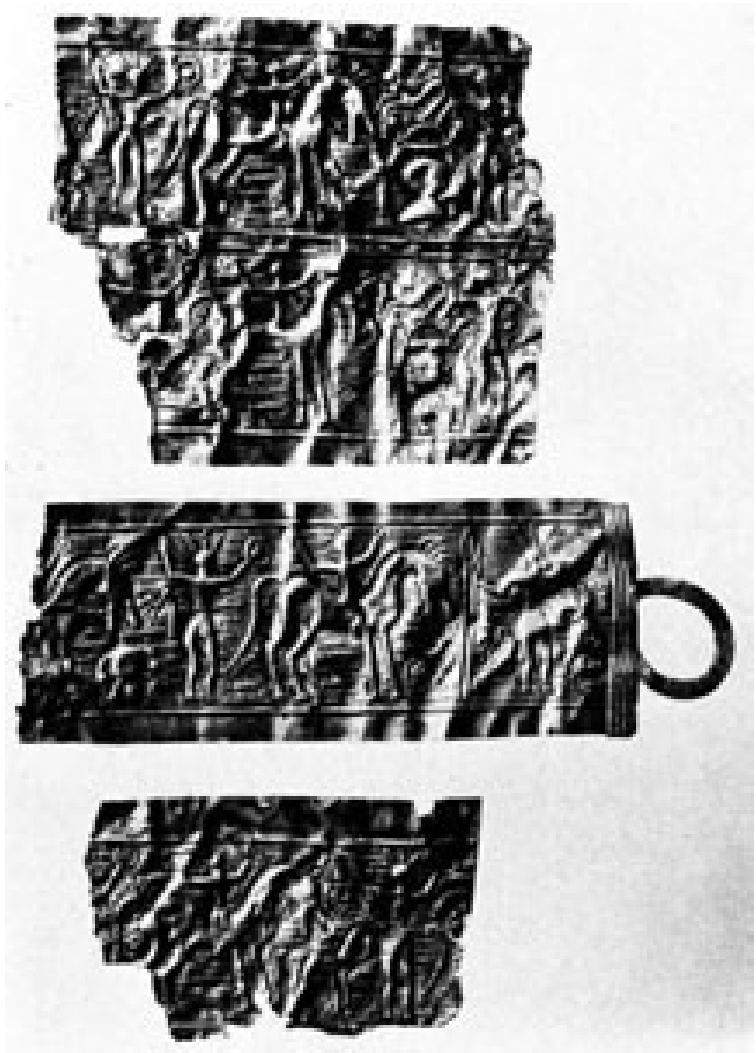

Figura 37: Fragmento de la diadema de Mones (Foto G. López Monteagudo).

propuesto una audaz y posible interpretación a la diadema de Mones (Fig. 37), aparecida en territorio de los astures lugones, en el occidente de Asturias. Sobre un fondo de líneas paralelas, que parecen representar el agua, se colocan figuras de rostro ornitomorfo, transportando calderos, infantes y jinetes con cascos coronados con cuernos de ciervo o de tres penachos, armados con armas ligeras, caetrae, espadas cortas o lanzas. También están representados peces, aves acuáticas, torques y perros. Estas escenas ofrecen paralelos con otras del ámbito celtíbero y de Europa: reflejan algunos aspectos claves de la religión céltica hispana, pues expresarían la heroización guerrera y el paso al Más Allá a través del agua, interpretación de gran novedad (Marco, 1993, 319-340. Blázquez, 1983, 239240, Fig. 147).

Generalmente se acepta una concepción astral de la ultratumba entre muchas poblaciones de la Hispania prerromana, como ya se ha indicado (Blázquez, 1983, 269-270, Figs. 170-173). Los celtas de la Galia creían en la metempsicosis, según César ( $B g$. VI, 1,5$)$ que los conocía bien y directamente. Diodoro $(\mathrm{V}, 28,6)$ recoge las mismas creencias, y Lucano (Fars. I, 454-458) al 


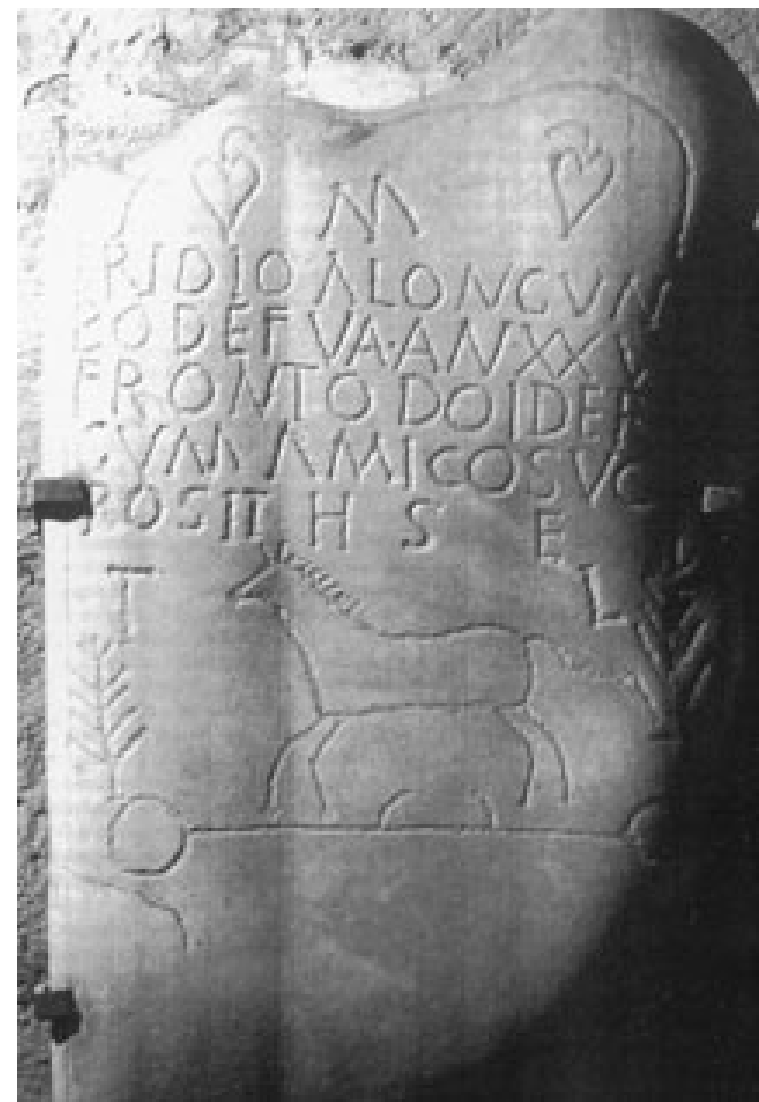

Figura 38: Estela vadiniense con caballo y hojas de hiedra de la Remolina,Villayandre (Foto I. Sastre).

referirse a las creencias de los druidas sobre la ultratumba. El único testimonio del paso al Más Allá a través del agua entre las poblaciones de la Hispania Antigua, es la estela de Vilar de Sarria, Lugo, con nave con cuatro pasajeros interpretada, falsamente, como el mito de Ulises y las sirenas, mito que lleva siempre a Ulises atado al mástil. La presencia del águila da un carácter funerario al relieve. El águila es símbolo de la apoteosis (Acuña, 1976, 68).

Se han propuesto otras interpretaciones a esta importante pieza procedente del territorio ocupado por la tribu de los albiones. Según G. López Monteagudo (1997, 99-108), la diadema de oro llamada de Ribadeo es una joya masculina perteneciente seguramente a un jefe, a juzgar por la escena en ella representada y el material de lujo en que está realizada. Cree esta autora que se trata de una ceremonia religiosa, tal vez de carácter funerario, en la que el agua juega un papel primordial, en relación con el ritual propio de los pueblos del Norte de la Península Ibérica, de arrojar las armas del difunto a las corrientes fluviales. A juzgar por los paralelos con la escena de sacrificio representada en un cuchillo ritual del
Instituto Valencia de Don Juan, en la que también aparecen un caldero, una cría de caballo y un torques, López Monteagudo se inclina a interpretar esta escena como un ritual de sacrificio, hipótesis además avalada por la presencia de "cabezas cortadas" en uno de los extremos de la banda, en relación con un culto al ciervo o a Cernunnos, ya que algunos de los guerreros representados llevan cascos adornados con cuernos. En estudios posteriores la autora se plantea la posibilidad de que se trate de una escena de lustratio en honor de Marte. Al tratarse de un hallazgo sin contexto arqueológico, la diadema de Ribadeo constituye un elemento material de la cultura castreña, cuya fecha fluctúa entre el siglo III y el I a.C.

\section{CABALLO FÚNEBRE ENTRE LOS CARTAGINESES}

En Marchena se ha hallado un cipo funerario con un caballo al galope (Blázquez, 1963, 410. García y Bellido, 1949, 365, Fig. 304). Se ha considerado cartaginés o romano. Muy probablemente es cartaginés, como se desprende de la presencia de una palmera en uno de los lados. Al cambio de Era, la Bética estaba habitada por gran número de cartagineses, según la afirmación de Estrabón (III, 2, 3) que, aunque no estuvo en Hispania, se informó de ella, pues obtuvo los datos de autores griegos que la visitaron, como Polibio (Str. III, 1, 6; 2, 7, 9, 11, 15; 4, 13; 5, 5, 7, 11), Posidonio (Str. III, 1, 5; 2, 5, 9; 3,3-4; IV, 3, $13,15,17 ; 5,5,7-10)$, que vino a Cádiz a estudiar el fenómeno de las mareas, a comienzos del s. I a.C., Asclepíades de Mirlea (Str. III. 4. 3. 19) y Artemidoro de Éfeso (Str. III. 1. 4-5; 2, 11; 4, 3, $7,17 ; 5,1,5,7)$, que escribió sobre sus pueblos. Un fragmento de su obra, referente a la Bética, se ha hallado en un papiro (Gulletta, 2006, 100109). Agripa, que estuvo en Hispania organizándola después de la terminación de las Guerras Cántabras, 19 a.C., afirma lo mismo (Plin., NH III, 8) sobre la población del sur de la península.

\section{LAS ESTELAS VADINIENSES CON CABALLOS}

En el norte de Hispania han aparecido varias estelas (Fig. 38) con caballos, del más alto interés. Se conservan casi todas en el Museo Arqueológico de León. La de Liegos, en el valle del Burón, está labrada en un canto de río. Debajo de la inscripción se grabó una cruz grande y un caballo en actitud de marcha. La cruz es un signo astral 
colocado en Numancia sobre caballos, toros y peces, y en estelas, como en una de Vigo.

En la parte superior derecha hay una palma de claro sentido funerario. La inscripción está dedicada por Aliomus a su hija. Aliomus es un nombre no documentado en la antroponimia hispana.

La inscripción de Valmartino está dedicada por Dovidena, que es antropónimo indígena hispano bien atestiguado en Hispania (Albertos, 1966, 106, Mapa 4). El caballo está debajo de la inscripción. El difunto, Negalus, es un indígena (Albertos, 1966, 167). En la inscripción de Villapadierna, el nombre del dedicante, Cancilus, se repite en Lusitania (Albertos, 1966, 74). El nombre del difunto es frecuente entre los pueblos del norte de Hispania, Vironus (Albertos, 1966, 251-252). Se hace constar que es vadiniense. Vadinia es ciudad citada por Ptolomeo (II, 6, 50). Se desconoce su localización. Las inscripciones vadinienses guardadas en el Museo de León son unas treinta, y son diferentes de las restantes inscripciones leonesas. Todas están grabadas sobre cantos rodados de cuarcita. El caballo está, generalmente, debajo de la inscripción. El nombre del difunto de una inscripción de Riaño, Uranus (Albertos, 1966, 255), es desconocido en Hispania. El caballo sigue a la inscripción. En una segunda lápida procedente de Riaño, el caballo se encuentra en la última línea.

En la lápida hallada en Barmiedo, el caballo ocupa el lugar superior de la inscripción. El antropónimo del dedicante, Ambatus, está bien documentado en Hispania (Albertos, 1966, 2021). En la lápida de Lois se lee el mismo nombre del dedicante de la pieza anterior. Se hace constar expresamente que es vadiniense. El nombre del padre, Paramo, sólo se lee en dos inscripciones vadinieses (Albertos, 1966, 176-177) y el antropónimo, Origenus, del dedicante, sólo aparece en esta inscripción (Albertos, 1966, 173). El caballo se encuentra, al igual que en la lápida de Argovijo sobre el río Esla. Se hace constar también que el difunto es vadiniense, Turennus, nombre que sólo se documenta aquí (Albertos, 1966, 238). El patronímico Boddus, que se relaciona con el gentilicio, aparece tres veces (Albertos, 1966, 47).

En la lápida encontrada en Proro o Sorbias, el caballo corona la inscripción. El nombre del dedicante, Labarus, no está atestiguado en Hispania (Albertos, 1966, 126-127).

En la inscripción de Lieges el caballo vuelve al final de la inscripción, al igual que en otra, hoy conservada en el Museo de León, donde también se indica que el difunto es vadiniense.
El antropónimo del dedicante, Doiderus, está atestiguado en la montaña de León lindando con Asturias y Santander, que debía ser la zona de los vadinienses (Albertos, 1966, 107). El nombre del difunto, Tridius, es indígena.

De particular interés es la lápida de San Juan de Beleña, hoy en el Museo Arqueológico de Oviedo, pues en las tres últimas líneas van un caballo, y un ciervo y un caballo. Es interesante señalar que el nombre del difunto, Septimio Silo, hermano del dedicante, Aelius, se lee dentro del cuerpo del caballo. Lo mismo se repite en la inscripción de la Colección Soto Cortés, donde el nombre de la difunta, Flavia, se repite dentro del caballo. En una inscripción que estuvo en una colección particular de Bilbao, se hace constar que el difunto es vadiniense. El caballo se coloca, como casi siempre, debajo de la última línea.

En una inscripción funeraria dedicada a una mujer en San Juan de Beleña, se colocó un caballo y una posible palma, de carácter fúnebre. En la parte superior hay un dibujo con una persona en el interior, que llevaba un bastón. Delante camina probablemente una vaca. Dentro del caballo parecen estar grabadas las primeras letras de la difunta muerta siendo una niña (Blázquez, 1977, 266-277. Rabanal y García Martínez, 2001, 383-384, Lám. LXXXV 3; 386-387, Lám. LXXXVI 2; 390-391, Lám. LXXXVII 2; 394-396, Lám. LXXXVIII 2-4; 402-403, Lám. LXXXIX 4; 404-405, Lám. XC 3; 407-408, Lám. XC 1; 409410, Lám. XC 3; 415-416, Lám. XCIII 1; 418-419, Lám. XCIII 4; 419-422, Lám.XCIV 31. Sastre, 2002, 79-102).

Estas estelas con caballos son típicas de una región concreta, Vadinia. Pertenecen a un pueblo de pastores de caballos.Los dedicantes y los difuntos de estas inscripciones son indígenas. A la figura del caballo en estas lápidas funerarias se las ha interpretado de diferentes modos. Para F. Cumont (1942, 434, n. 1), la figura del caballo indica que el muerto está heroizado. En las dos estelas vadinienses con el nombre del difunto dentro del cuerpo del caballo, sólo cabe interpretarlo como la sustitución de la imagen del difunto por la figura del caballo. Esta sustitución se documenta también en Grecia, según Malten y Ferri (1993, 157, Fig. 17).

Las palmas son símbolo de triunfo del difunto sobre la muerte. La presencia del ciervo se explica por ser un animal de carácter funerario igualmente, como lo indica la estela de Rabanales, una segunda conservada en el Museo de Pamplona, los ciervos sobre tumbas oretanas de Castulo o la cierva de Caudete (Blázquez, 1993, 245-247, Fig. 80). 


\section{LA HEROIZACIÓN ECUESTRE ENTRE LOS PUEBLOS DE LA VERTIENTE ATLÁNTICA Y DEL NOROESTE HISPANO}

Entre estos pueblos también se documentan varios testimonios de la heroización ecuestre. Baste recordar una estela de Tras-os-Montes (Portugal), con un caballo solo; de Monte Cildá, con jinete y en un casco con signos astrales en la parte superior, con jinetes marchando, y de Ciudadela, con caballo detrás del difunto (Blázquez, 1983, 272, Fig. 174. Pereira, 1991, 34-35). Esta última figura se ha interpretado como un Dioscuro, pero estos son desconocidos en Hispania.

Profa. María Paz García-Gelabert Pérez
Dpto. de Historia de la Antigüedad y de la
Cultura Escrita
Facultad de Geografía e Historia
Avda. Blasco Ibáñez, 28
Universidad de Valencia
46010 Valencia
Prof. José María Blázquez Martínez
Real Academia de la Historia
c/ León, 21
28014 Madrid

\section{BIBLIOGRAFÍA}

ABASOLO, J.A., 1974: Epigrafía romana de la región de Lara de los Infantes, Burgos.

ACUÑA, F., 1976: "La cultura en la Galicia romana", La romanización de Galicia, Cuadernos del seminario de Estudios Cerámicos de Sargadelos, 16, La Coruña.

AKURGAL, E., 1962: L'arte degli Ittiti, Florencia.

AKURGAL, E., 1969: Orient et Occident, París.

ALMAGRO-GORBEA, M., 1977: El Bronce Final y el Periodo Orientalizante en Extremadura, BPH, 14, Madrid.

ALMAGRO-GORBEA, M., 1995a: Iconografía numismática hispánica: jinete y cabeza varonil, La moneda hispánica: ciudad y territorio, Anejos de Archivo Español de Arqueología, 14, 53-64.

ALMAGRO-GORBEA, M., 1995b: "La moneda hispánica con jinete y cabeza varonil: ¿tradición indígena o creación romana?", Zephyrus, 48, 235-266.

ALMAGRO-GORBEA, M., 1996: Ideología y poder en Tartessos y en el mundo ibérico, Madrid.

ALMAGRO-GORBEA, M., 1997: Guerra y sociedad en la Hispania Céltica, VV.AA., La guerra en la antigüedad. Una aproximación al origen de los ejércitos en Hispania, Madrid.

ALMAGRO-GORBEA, M., 2001: Celtas y Vetones, Ávila.

ALMAGRO-GORBEA, M., 2005: Ideología ecuestre en la Hispania prerromana, M. BARRIL, F. QUESADA (coords.), El caballo en el mundo prerromano, Actas de la reunión celebrada en el Museo Arqueológico Nacional el 2 de marzo de 2005, Gladius, 15, 59-94.

ALMAGRO-GORBEA, M., RUBIO, F., 1980: "El monumento ibérico de "Pino Hermoso", Orihuela (Alicante)", TP, 37, 345-362.

ALMAGRO-GORBEA, M., TORRES, M., 1999: Las fíbulas de jinete y de caballito. Aproximaciones a las élites ecuestres y su expansión en la Hispania Céltica, Zaragoza.
AMADASI, M.G., 1965: Iconografía dal carro da guerra in Siria e Palestina, Roma.

ARANEGUI, C., 1997: Les ibères, París.

ARANEGUI, C., 1998: Los iberos a través de sus imágenes, VV.AA., Los Iberos. Príncipes de Occidente. Catálogo, 175-189. Barcelona.

AUBET, M.E., 1976: Algunos aspectos sobre iconografía púnica: las representaciones aladas de Tanit, Homenaje a $A$. García y Bellido, I, Revista de la Universidad Complutense, 25, 61-82.

BARCELO, J.A., 1998: "Las estelas decoradas del sudeste de la Península Ibérica", Tartessos. Arqueología Protohistórica del Bajo Guadalquivir, Sabadell.

BARRIL, M., QUESADA F. (coords.), 2005: El caballo en el mundo prerromano, Actas de la reunión celebrada en el Museo Arqueológico Nacional el 2 de marzo de 2005, Gladius, 15.

BENDALA, M., QUESADA, F., 1995: El caballo en la Bética romana, Al-Andalus y el caballo, 51-65. Jerez de los Frontera.

BELTRÁN, M., 1979: "La cerámica campaniense de Azaila. Problemas de cronología del valle medio del Ebro", Caesaraugusta, 47/48.

BELTRÁN, M., 1996: Los iberos en Aragón, Zaragoza.

BELTRÁN, F., 2001: "Hacia un replanteamiento del mapa cultural y étnico del norte de Aragón", Religión, lengua y cultura prerromanas de Hispania, Salamanca.

BENOIT, F., 1950: Les mythes de l'outre-tombe. Le cavalier à l'anguipède et l'écuyère Epona, Bruselas.

BENOIT, F., 1954: L'héroisation équestre, París.

BERMEJO, J., 1982: Mitología y mitos de la Hispania prerromana, Madrid.

BIANCHI BANDINELLI, R., 1970: Roma, centro del poder, Madrid.

BIANCHI BANDINELLI, R., GIULIANO, A., 1973: Los etruscos y la Italia anterior a Roma, Madrid.

BIANCHI BANDINELLI, R., TORELLI, M., 1986: Etruria Roma, Turín.

BITTEL, K., 1976: Los hititas, Madrid.

BLANCO FREIJEIRO, A., 1981: "Cancho Roano un monumento protohistórico en los confines de la antigua Lusitania", BRAH, 188, 225-241.

BLANCO FREIJEIRO, A., 1996: "Un jinete ibérico de Cástulo", Antonio Blanco Freijeiro. Opera minora selecta, Sevilla.

BLANCO FREIJEIRO, A., 1996: "Las esculturas de Porcuna I. Estatuas de guerreros", Antonio Blanco Freijeiro. Opera minora selecta, Sevilla.

BLANCO GARCÍA, J.F., 2005: Iconografía del caballo entre los pueblos prerromanos del centro-norte de Hispania, M. BARRIL, F. QUESADA (coords.), El caballo en el mundo prerromano, Actas de la reunión celebrada en el Museo Arqueológico Nacional el 2 de marzo de 2005, Gladius, $15,75-123$.

BLÁNQUEZ, J.J, 1992: “Las necrópolis ibéricas en el sureste de la Meseta”, Congreso de Arqueología Ibérica. Las necrópolis, Madrid.

BLÁZQUEZ, J.M., 1955: "Los carros votivos de Mérida y Almorchín. Su significación religiosa", Zephyrus, 5.

BLÁZQUEZ, J.M., 1957: "La economía ganadera de la España Antigua a la luz de las fuentes literarias griegas y romanas", Emerita, 25.

BLÁZQUEZ J.M., 1957-1958: "Caballos en el infierno etrusco", Ampurias 19-29.

BLÁZQUEZ, J.M., 1962: Religiones primitivas de España. I. Fuentes literarias y epigráficas, Madrid.

BLÁZQUEZ, J.M., 1963, "L'héroisation écuestre dans la Péninsule Ibérique", Celticum, 6. 
BLÁZQUEZ, J.M., 1975: Diccionario de las Religiones Prerromanas de Hispania, Madrid.

BLÁZQUEZ, J.M., 1976: Bronces de la Mérida Prerromana, Augusta Emerita. Actas del Simposio Internacional conmemorativo del bimilenario de Mérida, Madrid.

BLÁZQUEZ, J.M., 1977: Cástulo II, Madrid.

BLÁZQUEZ, J.M., 1982: "Marfiles fenicios de Cancho Roano (Badajoz) con el árbol de la vida y sus prototipos", Boletín de la Asociación Española de Orientalistas, 17.

BLÁZQUEZ, J.M., 1983: Primitivas religiones ibéricas. T. II. Religiones prerromanas, Madrid.

BLÁZQUEZ, J.M., 1988: Historia del Arte Hispánico. I. La Antigüedad, Madrid.

BLÁZQUEZ, J.M., 1992: Fenicios, griegos y cartagineses en Occidente, Madrid

BLÁZQUEZ, J.M., 1997: "Astarté: señora de los caballos en la Hispania prerromana”, RSF, 25, 1, 79-100.

BLÁZQUEZ, J.M., 1999: Sirios y arameos en la colonización fenicia de Occidente, Mitos, dioses, héroes, en el Mediterráneo Antiguo, Madrid.

BLÁZQUEZ, J.M., 1999: Los rituales funerarios de la tumba tracia de Kazanlak y sus paralelos en Grecia, Etruria, Campania, Lazio, la Península Ibérica y Chipre, Mitos, dioses, héroes en el Mediterráneo Antiguo, Madrid.

BLÁZQUEZ, J.M., 2000: La Península y Chipre antes de los romanos, Los pueblos de España y el Mediterráneo en la Antigüedad, Estudios de Arqueología. Historia y Arte, Madrid.

BLÁZQUEZ, J.M., 2000: Ritual funerario y status social: los combates gladiatorios prerromanos en la Península Ibérica, Mitos, dioses, héroes, en el Mediterráneo Antiguo, Madrid.

BLÁZQUEZ, J.M., 2001: Religiones, ritos y creencias funerarias de la Hispania Prerromana, Madrid.

BLÁZQUEZ, J.M., 2001-2002: "El vaso de los guerreros de El Cigarralejo (Mula, Murcia)", An. Murc., 17-18.

BLÁZQUEZ, J.M., 2003: Alejandro Magno, homo religiosus, Los pueblos de España y el Mediterráneo en la Antigüedad, Madrid.

BLÁZQUEZ, J.M., 2006: Monarquías divinas. Religiosidad ibera y religión mediterránea. Algunos aspectos de la religión ibera, El Mediterráneo. Historia, Arqueología, Religión, Arte, Valladolid.

BLÁZQUEZ, J.M., REMESAL, J., 1979: La necrópolis del Estacar de Robarinas, J.M. BLÁZQUEZ, Castulo II, EAE, 105, 347-395. Madrid.

BLECH, M., 1992: Hispania Antigua: Denkmäler der Frühzeit, Maguncia.

BLEEKER, C.J., WIDENGREN, G., 1973: Historia Religionum. I. Religiones del pasado, Madrid.

BOARDMAN, J., 1998: Early Greek Vase Peinting, Londres.

BOËTHIUS, A., 1962: Etruscan Culture. Land and People, Malino.

BONET, H., IZQUIERDO, I., 2001: "Vajilla ibérica y vasos singulares del área valenciana entre los siglos III y I a.C. (1)", APL, 24, 273-313.

BRONSON, R.C., 1965: Chariot Racing in Etruria, Studi in onore di Luisa Banti, Florencia.

CAMPOREALE, G., 2000: Gli Etruschi. Storia e civiltà, Turín

CAPALVO, A., 1996: Celtiberia. Un estudio de fuentes literarias antiguas, Zaragoza.

CARO BAROJA, J., 1971: "La realeza y los reyes en la España Antigua", Estudios sobre la España Antigua, Madrid.

CELESTINO, S., 2001: Estelas de guerrero y estelas diademadas. La precolonización y formación del mundo tartésico, Barcelona.
CROUWEL, J.M., 1987: "Chariot in Iron Age Cyprus", Reports of the Department of Antiquities Cyprus, Nicosia.

CUADRADO, E., 1950: Excavaciones en el santuario ibérico del Cigarralejo (Mula, Murcia), Informes y Memorias, 21, Madrid.

CUADRADO, E., RUANO, E, 1989: "Esculturas de équidos procedentes de la Colección de Alhonoz (Puente- Genil, Córdoba)", TP, 46, 203-228.

CUMONT, J.F., 1942: Recherches sur le symbolisme funeraire des romains, París.

CHARLISH, A., y otros, 1981: Un mundo de caballos, Munich-Mönchengladbach.

EIROA, J.J., 1986: "El kalathos de Elche de la Sierra (Albacete)", Anales de Prehistoria y Arqueología, An. Murc., 2, 73-86.

EMILIOZZI, A., 2000: Carri da guerra e principi etruschi, Roma.

FERNÁNDEZ CASTRO, M.c., 1988: Arqueología Protohistórica de la Península Ibérica (siglos X a VIII a.C.), Madrid.

FERNÁNDEZ GÓMEZ, F., 2003: Los caballos de Luque, F. QUESADA, M. ZAMORA, (eds.), El caballo en la antigua Iberia, 21-61. Madrid.

FERNÁNDEZ NIETO, F.J., 1999: La Federación celtibérica de Santerón, F. VILLAR, F. BELTRÁN (eds.), Pueblos, lenguas y escrituras en la Hispania prerromana. Actas del VII Coloquio sobre lenguas y culturas paleohispánicas, celebrado en Zaragoza los días 12-17 de marzo de 1997, 183-201. Salamanca.

FERNÁNDEZ-MIRANDA, M., OLMOS, R., 1986: Las ruedas de Toya y el origen del carro en la Península Ibérica, Madrid.

FERRI, S., 1993: Archeologia Della "Protome", Annali della R. Scuola di Pisa 2/2, Pisa.

GABALDON, M. DEL M., QUESADA, F., 1998: “¿Jinetes y caballos en el Más Allá ibérico?, un vaso cerámico en el Museo Arqueológico de Linares", Revista de Arqueología, 201, 16-23.

GARCÍA Y BELLIDO, A., 1949: Esculturas romanas de España y Portugal, Madrid.

GARCÍA Y BELLIDO, A., 1971: Arte Ibero, Madrid.

GARCÍA-BELLIDO, M.P., 1993: Origen y función del denario ibérico, Sprachen und Schriften des Antiken Mittelmeeraums. Fetschrift für J.Untermann, 97-115. Innsbruck.

GARCÍA CANO, J.M., 1997: Las necrópolis ibéricas de Coimbra del Barranco Ancho (Jumilla, Murcia). I. Las excavaciones y estudio analítico de los materiales, Murcia.

GARCÍA-GELABERT, M.P., 1988: La necrópolis del Estacar de Robarinas, Jaén: ritos y creencias, Madrid.

GARRIDO, J.P., ORTA, E.M., 1978: Excavaciones en la necrópolis de "La Joya", Huelva. II. ( $3^{a}, 4^{a}$ y $5^{a}$ campañas), $E A E, 96$, Madrid.

GONZÁLEZ ALCALDE, J., 1997: "Simbología de la diosa Tanit en representaciones cerámicas ibéricas", Quad. Preh. Arq.Cast., 18, 329-358.

GRÜNHAGEN, W., 1979: "Eine Weihung für Dis Pater in Munigua", $M M, 17,226-237$.

GUADÁN, A.M., 1979: Las armas en la moneda ibérica, Madrid.

GULLETTA, M.I.P.: "La Península Ibérica in età romana", Le tre vite del papiro di Artemidoro. Voci e sguardi dall'Egitto greco-romano, Milán.

JIMENO, A., 1980: Epigrafía romana de la provincia de Soria, Soria.

JIMENO, A., 2005: Celtíberos tras la estela de Numancia, Soria.

KARAGEORGHIS, V., 1969, Salamis in Cyprus. Homeric, Hellenistic and Roman, Londres. 
KARAGEORGHIS, V., 1997: An enthroned Astarte on Horseback? Report of the Department of Antiquities, Cyprus, Nicosia, 195-206.

KARAGEORGHIS, V., 2000: Ancient Art from Cyprus. The Cesnola Collection, Singapur.

KUKHAHN, E., 1962: "Los símbolos de la Gran Diosa en la pintura de los vasos ibéricos levantinos", Caesaraugusta, 19-20, 79-85.

LEPPER, F., FRERE, SH.: 1988, Trajan's Column. A new Edition of the Cichorius Plates. Introduction, Commentary and Notes, Alan Sutton.

LINCOLN, B., 1991: Sacerdotes, guerreros y ganado, Madrid.

LÓPEZ MONTEAGUDO, G., 1989: Esculturas zoomorfas celtas de la Península Ibérica, Madrid.

LÓPEZ MONTEAGUDO, G., 1997: "La diadema de San Martín de Oscos", Revista de la Universidad Complutense, 26.

LORRIO, A., 1997: Los celtíberos, Murcia.

LORRIO, A., ALMAGRO-GORBEA, M., 2004-2005: "Signa equitum en el mundo ibérico. Los bronces tipo "Jinete La Bastida" y el inicio de la aristocracia ecuestre ibérica", Lucentum, 22-24.

LUZÓN, J.M., LEÓN, P. (eds.),1996: Antonio Blanco Freijeiro. Ópera Minora Selecta, Sevilla.

MAESTRO, E.M., 1989: Cerámica ibérica decorada con figura humana, Zaragoza.

MALTEN, L., 1914: "Des Pferdin Totenglauben", JAI, 29.

MALUQUER, J., 1981: El santuario protohistórico de Zalamea de la Serena, Badajoz, 1978-1981, Barcelona.

MALUQUER, J., AUBET, M.E., 1981 : Andalucía y Extremadura, Barcelona.

MARCO, F., 1993: "Heroización y tránsito acuático. Sobre las diademas de Mones (Piloña, Asturias), Homenaje a José $M^{a}$ Blázquez, Madrid.

MARCO, F., 1994: La religión indígena en la Hispania indoeuropea, J.M. BLÁZQUEZ y otros, Historia de las religiones de la Europa Antigua, 313-400. Madrid.

MARCO, F., 1998: Deis Equevnv (Bo* ${ }^{*}$, Pueblos, lenguas y escrituras en la Hispania prerromana, Actas del VII Coloquio sobre lenguas y culturas paleohispánicas (Zaragoza, 1997), 481-490. Zaragoza.

MARÍN CEBALLOS, M.C., 1987: “¿Tanit en España?”, Lucentum, 6, 43-79.

MARÍN CEBALLOS, M.C., PADILLA MONGE, A., 1997: "Los relieves del "domador de caballos" y su significación en el contexto religioso ibérico", Quad. Preh.Arq.Cast., 18, 461-494.

MARTÍNEZ PINNA, J., 1996: Tarquinio Prisco, Madrid.

MARTÍNEZ PINNA, J., 1999: Los orígenes de Roma, Madrid.

MENÉNDEZ, M., 1988: La cerámica ibérica del estilo ElcheArchena, Universidad Complutense, Madrid.

MORIGI, C. (dir.), 2001: Etruschi: tra Mediterráneo ed Europa, Venecia

NAVARRETE, J.A., 1992: Escultura ibérica del Cerrillo Blanco, Porcuna, Jaén, Madrid.

NEGUERUELA, I., 1990: Los monumentos escultóricos ibéricos del Cerrillo Blanco de Porcuna (Jaén), Madrid.

NILSSON, M.P.: Geschichte der griechische Religión, Munich.

OLMO LETE, G. DEL, 1992: La religión cananea según la liturgia de Ugarit. Estudio actual, Sabadell.

PADRÓ, J., 1983: Los orígenes de la civilización mesopotámica, VV.AA., Historia Universal, vol. II. Antiguo Oriente, 39-81. Madrid.

PALLOTTINO, M., 1952: La peinture étrusque, Ginebra.
PALLOTTINO, M., 1984: Etruscologia, Milán.

PEREIRA, G. (ed.), 1991: Corpus de inscripciones romanas de Galicia. I. Provincia de A Coruña, Santiago de Compostela

PERICOT, L., 1979: La cerámica ibérica, Barcelona.

PFIFFIG, A.J., 1975: Religio Etrusca, Graz.

POLLITT, J.J., 1989: Arte helenístico, Madrid.

PONTRANDOLFO, A., ROUVERET, A., 1992 : Le tombe dipinti di Paestum, Módena.

POULSEN, V., 1962: Etruscan Culture. Land and People, Milán.

PUGLIESE CARRATELLI, G. (coord.), 1990: Magna Grecia. Arte e artigiato, Milán.

QUESADA, F., 1993: "Datos para una filiación egea de los carros grabados en las "Estelas del Sureste", V Congreso Internacional de estelas funerarias, Soria.

QUESADA, F.,1997: ¿Jinetes o caballeros?: en torno al empleo del caballo en la Edad del Hierro, VV.AA., La guerra en la antigüedad. Una aproximación al origen de los ejércitos en Hispania, 185-195. Madrid.

QUESADA, F., 2005: El gobierno del caballo montado en la antigüedad clásica con especial referencia al caso de lberia. Bocados, espuelas y la cuestión de la silla de montar, estribos y herraduras, M. BARRIL, F. QUESADA F. (coords.), El caballo en el mundo prerromano, Actas de la reunión celebrada en el Museo Arqueológico Nacional el 2 de marzo de 2005, Gladius, 15, 155-58.

QUESADA, F., ZAMORA, M. (eds.), 2003: El caballo en la antigua Iberia, Madrid.

RABANAL. M.A., GARCÍA MARTÍNEZ, S.M., 2001: Epigrafía romana de la provincia de León: revisión y actualización, León.

RAMOS, R., 1991: Simbología de la cerámica ibérica de La Alcudia de Elche, Elche.

RICHTER, G.M.A., 1961: The Archaic Gravestones of Attica, Londres.

RICHTER, G.M.A., 1960: Kouroi. Archaic Greek Youths, Londres.

ROBERTSON, M., 1959: La Peinture Greque, Ginebra.

RODRÍGUEZ, P., PEREGRÍN, F., ANDERICA, R., 1983: Exvotos ibéricos con relieves de équidos en la vega granadina, Actas del XVI Congreso Nacional de Arqueología (Murcia, Cartagena, 1982), 751-768. Zaragoza.

SÁNCHEZ MORENO, E., 2005: Caballo y sociedad en la Hispania céltica. Del poder aristocrático a la comunidad política, M. BARRIL, F. QUESADA (coords.), El caballo en el mundo prerromano, Actas de la reunión celebrada en el Museo Arqueológico Nacional el 2 de marzo de 2005, Gladius, 15, 145-172.

SCHULTEN, A.: Fontes Hispania Antiquae IV. Las guerras de 154-72 A. de J.C., Barcelona.

SEECK, O., 1961: Q. Aurelii Symmachi quae supersunt, Berlín.

SPITERIS, T., 1970: Art de Chypre des origines à l'époque romaine, París.

SPRENGER, M., BARTOLONI, G., 1977: Etruschi. L'arte, Milán.

STEINGRÄBER, ST., 1984: Catalogo ragionato della Pittura etrusca, Milán.

UNTERMANN, U., 1985: Hispania Antiqua. Denkmäler der Frühzeit, Maguncia.

URRUELA, J.J. 1984: Los sondeos I, II, III y IV, J.M.BLÁZQUEZ, R. CONTRERAS, J.J. URRUELA, Castulo IV, EAE, 131, 13-51.

VAQUERIZO, D., 1997: "Los santuarios ibéricos de la provincia de Jaén", Quad. Preh.Arq.Cast., 18.

VARAGNAC, A., FABRE, G., 1956: L'art Gaulois, Yonne. 
VISEDO, C., 1947: "Sobre un bajorrelieve que figura en el Museo de Arte de Alcoy", Actas del II Congreso Arqueológico del Sudeste Español (Albacete, 1946), 279-282. Albacete.

VV.AA., 1987: Escultura Ibérica, Revista de Arqueología, vol. extraordinario, Madrid.

VV.AA., 1996: El mundo ibérico. Una nueva imagen en los albores del año 2000. Catálogo, Valencia.
VV.AA., 1997: La guerra en la Antigüedad. Una aproximación al origen de los ejércitos en Hispania. Catálogo, Madrid.

VV.AA., 1998: Los Iberos. Príncipes de Occidente. Catálogo, Barcelona.

XELLA, P., 2002: Da Edwin Rohde ai rapiuma ugaritici: antecedente vicino orientali degli eroi greci, La questione delle influenza vicino-orientali sulla religione greca, Roma.

YALOURIS, A., 1950: "Athena als Herrin der Pferde", Museum Helveticum, 89-96. 